\title{
GOVERNMENT MANAGEMENT OF OIL AND GAS IN ALBERTA*
}

\author{
MICHAEL CROMMELIN**
}

The author surveys, in considerable detail, the broad spectrum of provincial legislation and regulations relating to the exploration, development, and marketing of conventional Crown-owned oil and natural gas in Alberta. He evaluates and criticizes government management of these resources by reference to two criteria. The first such criterion is that of optimum "efficiency", which the author describes as being such allocation of labour and capital at such time as will result in the maximum possible net benefit to society. The second criterion is that of "equity", by which is meant a distribution of benefits between government and private enterprise such that those revenues, in excess of necessary costs incurred and adequate compensation for risk-taking by private enterprise, accrue to the government. In applying these criteria, the author develops several criticisms of the excisting management system. He concludes by proposing several specific changes.

The essential principle of property being to assure to all persons what they have produced by their labour and accumulated by their abstinence, this principle cannot apply to what is not the produce of labour, the raw material of the earth. If the land derived its productive power wholly from nature, and not at all from in. dustry, ... it not only would not be necessary, but it would be the height of injustice, to let the gift of nature be engrossed by individuals.

John Stuart Mill.

\section{INTRODUCTION}

The discovery of the Leduc field in 1947 marked the establishment of Alberta as a major oil and gas producing province. In the 28 years since then, Alberta has never been seriously challenged for its position as the leading producer of oil and gas in Canada. At the same time, the dominance of the oil and gas industry in the economy of Alberta has never been open to question.

The Crown in right of the province owns some 80 percent of minerals in the ground, including oil and gas. Nevertheless, in many respects the Crown has been the passive partner of private enterprise in the development of these resources. The influence of private ownership of minerals has been disproportionately strong, perhaps because the earliest discoveries were made in areas where such ownership was significant, ${ }^{1}$ and certainly because experience in the development of these resources was gained from Texas, Louisiana, Oklahoma and California, where private ownership was the norm. Alberta has maintained an unbroken tradition of reliance upon private enterprise for the conduct of exploration and production operations for Crown minerals as well as for those subject to private ownership, and when problems have arisen requiring government intervention, the protection of private rights has been paramount in any solution adopted.

The subject of this essay is government management of Crown oil

-This article forms part of a Ph.D. thesis submitted by the author to the Faculty of Graduate Studies at the University of British Columbia. The author would like to express his thanks to the many people who aided him in the preparation of this paper. The author is, of course, solely responsible for all opinions expressed in the article together with any factual errors that may be contained therein. Much of the research was financed by a grant from the Department of Energy, Mines and Resources to study, inter alia, the operations of the Energy Resources Conservation Board in Alberta.

**B., LL.B. (Hons.) (Qld.), LL.M., Ph.D.(U.B.C.), Senior Lecturer-in-Law, University of Melbourne, Melbourne, Victoria, Australia.

1 The site of the Leduc discovery well, for example, was the farm of Mike Turta, where mineral rights were privately owned. 
and gas resources in Alberta. ${ }^{2}$ It is not an historical review of the different policies that have been adopted from time to time during Alberta's life as a producing province, but rather it is an analysis of the management system presently in force. As such, it deals with government action taken from the time of first allocation of private rights over Crown oil and gas, through the exploration and production phases of the industry, to the transportation, export and sale of the produced substances.

In order to give something more than a descriptive account of this management process, some method of evaluation needs to be adopted. Here, the management system is judged according to efficiency and equity criteria. The concept of efficiency is directed towards net social benefit. It thus takes into account the benefits derived by Alberta society from oil and gas resources as well as the costs incurred by society in finding, developing and using them. Two matters are important here: the amount of society's investment of labour and capital in producing these resources, and the timing of this investment. Firstly, if the amount of investment is too low, society will not obtain all the available benefits from these resources, while if the amount of investment is too high, the cost of producing these benefits, in terms of wasted labour or capital, will be excessive. Either way, net social benefits will not be at a maximum. Economic theory shows that this maximum is achieved when the marginal social benefits from investment equal the marginal social costs, that is to say, when the social benefits derived from investment of an additional unit of either labour or capital equal the social cost thereof. These social costs, in turn, are represented by the social benefits that could have been obtained by investment of that unit of labour or capital in its next most productive use. Secondly, the timing of investment has two aspects. Since society has a positive time preference, in that benefits won today have a greater value than similar benefits won at some point in the future, investment made too early or too late will be akin to excessive or inadequate investment. Furthermore, since one of the costs of using oil and gas resources today is the present value of the benefits that could have been obtained by deferring their use to a future time, society will obtain the maximum net benefits from oil and gas resources only by adoption of a time path for their use which makes the marginal benefits of present use equal to the present value of the marginal benefits of use at all future times. ${ }^{3}$

In summary, efficiency is defined in terms of the best possible allocation of society's resources among alternative employments, including present and future uses, which results in the largest possible total of net benefits to society. When an efficient allocation of resources is achieved no increases in net benefits may be obtained by increasing or decreasing the employment of any resource or by altering the time path of investment of consumption. ${ }^{4}$

There is no clear indication that the Alberta government has sought to manage Crown oil and gas resources with the objectives of efficiency

2 It is restricted to conventional oil and gas resources, thereby omitting reference to the quite different management system adopted for the oil sands and other heavy oil deposits.

3 This concept, described as "user cost", is developed fully in Scott, Natural Resources, The Economics of Conservation (1955).

- For a more detailed discussion of economic efficiency, see McDonald, Petroleum Conservation in the United States: An Economic Analysis (1971) at 59-92; Lovejoy, and Homan, Economic Aspects of Oil Conservation Regulation (1967) at 8-26; Campbell, Pearse, and Scott, Water Allocation in British Columbia: An Economic Assessment of Public Policy (1972) 7 U.B.C.L. Rev. at 247 and 248-252. 
in mind. Other factors such as the maintenance of employment in the oil and gas industry and the preservation of equity among individual producers are frequently mentioned and represent, of course, entirely legitimate government objectives. However, the value of efficiency as a benchmark for assessment of government actions lies in the fact that these other policies, to the extent that they result in a deviation from efficiency requirements, give rise to social costs which should always be recognized as the price paid for their pursuit.

The second criterion adopted in the assessment of Alberta's management system for oil and gas resources, that of equity, is employed in a somewhat narrow sense. It refers to the distribution of the benefits and costs arising from development of these resources, but only as between government and private enterprise. The matter of distribution among the different sectors of industry is left open. The approach adopted in the application of this equity criterion is that the government is obliged, in fulfilment of its duty to the Crown and the Alberta public, to collect the economic rents ${ }^{5}$ produced from development of Crown oil and gas resources or at least to explain, in terms of government policy, the reasons for distribution of any part of these economic rents among industry or any sections of the Alberta, Canadian or foreign public. This follows from the fact of public ownership of the majority of Alberta oil and gas resources. To the extent that the government fails to collect the economic rents generated by these resources, it allows the benefits of public property to be enjoyed by a sector of society rather than by society as a whole. Thus the question of equity is treated as between government on the one hand, and private industry and individuals on the other.

In addition, the failure by the Alberta government to capture a substantial proportion of the economic rents has efficiency as well as equity implications. This is due to the high level of investment in oil and gas operations from outside Alberta. In the absence of such external investment, the distribution of rents among private operators would not result in inefficiency because the rents would not be lost to Alberta society. This is not the case, though, where some private operators are not members of the Alberta public. To the extent that they obtain economic rents, the rents are lost to Alberta. Even if these rents are reinvested in Alberta by the private operators, the result is the same since reinvestment adds to the foreign indebtedness of Alberta society.

It should not be forgotten, of course, that Alberta is a province within the Canadian federation. This means that important questions of distribution arise between Alberta as an oil and gas producer and other provinces as consumers. In addition, there is the important question of the extent to which the federal government, either on its own account or on behalf of other provinces, should share in the benefits from resource development. These issues may impinge directly upon the management of Crown oil and gas resources. However, their resolution ultimately lies in the broader context of rights and responsibilities, both legal and political, under the Canadian constitution. In the first instance, it is legitimate to review the best management policies for Crown oil and gas from Alberta's point of view, since these provide benchmarks for assess-

5 Economic rents are defined as the surplus of revenues generated in the development of oil and gas resources over all necessary costs incurred in the process, including adequate compensation for risk and uncertainty, when development takes place at the socially-desired rate. Thus, private operators who contribute labour or capital to the development of publicly-owned oil and gas resources are fully compensated without resort to the economic rents. 
ment of various compromises that may be suggested in the national interest.

There are over two hundred companies engaged in exploration for, and production, of oil and gas in Alberta. The size of their operations varies, considerably, ranging from production of a few barrels of oil or a few thousand cubic feet of gas daily on the part of small independents to over two hundred thousand barrels of crude oil and natural gas liquids and almost five hundred million cubic feet of gas per day on the part of the largest majors. Eight companies are considered to have fully integrated Canadian operations comprised of exploration, production, transportation, refining and marketing. The remainder are involved only in exploration and production. The integrated companies' principal shareholders are all foreign companies, while the non-integrated companies have various ownership positions ranging from wholly Canadian-owned to wholly foreign-owned. A sizeable number of the Canadian companies are privately-owned although this number, and its composition, fluctuates constantly as does the makeup of that portion of the industry represented by the smaller producers. ${ }^{6}$

Production of crude oil and natural gas liquids averaged over 1.32 million barrels per day during 1973, the highest rate in Alberta's history. ${ }^{7}$ Oil is usually purchased from producers by refinery operators on a monthly basis. In 1973, only ten per cent of total production was consumed in Alberta, while 29 per cent was sent to other Canadian provinces and 61 percent was exported to the United States. ${ }^{8}$ Oil is carried out of the province by large diameter pipelines: the Interprovincial Pipeline to Saskatchewan, Manitoba, Ontario and the mid-western United States and the TransMountain Pipeline to British Columbia and the north-western United States.

In 1973, Alberta produced natural gas at an average rate of 7.16 billion cubic feet per day, of which some 5.7 billion cubic feet were available for sale after allowing for processing and fuel losses.9 Unlike crude oil and natural gas liquids, gas is usually purchased on long-term contracts, which last from 20 to 25 years, by transmission companies when the gas is carried out of the province and by utility companies for consumption therein. Alberta utilities bought 15 percent of total production in $1973 . .^{10}$ Gas destined for removal from Alberta is collected by the Alberta Gas Trunk Line Company Limited and is carried to border points where it enters the interprovincial pipelines of the transmission companies. TransCanada Pipe Lines Limited serves Canadian markets east of Alberta and exports to the eastern and midwest United States; Alberta and Southern Gas Company Limited supplies gas to California; and Westcoast Transmission Company Limited purchases small quantities of Alberta gas for carriage along with British Columbia gas in its system serving British Columbia and the north-west United States. In 1973, almost 40 percent of Alberta's production of natural gas was exported to the United States while more than 40 percent was consumed in British Columbia and other Canadian provinces as far east as Quebec. ${ }^{11}$

\footnotetext{
6 This account is taken from the report of the Energy Resources Conservation Board entitled Field Pricing of Gas in Alberta, ERCB Report 72-E-OG, August, 1972 at 3-1.

7 Cumulative and Annual Statistics, Alberta Oil and Gas Industry, ERCB Report 74-17, 1973 at 5.

8 Id. at 4.

Id. at 8.

10 Id. at 7.

11 Id. at 7 .
} 


\section{ALLOCATION OF OIL AND GAS RIGHTS}

The first stage in government management of Crown oil and gas resources in Alberta is usually the allocation to private enterprise of exploration and production rights. This is a most important step, for it establishes private enterprise in the management process right from the beginning and limits the scope of future government action in relation to the development of publicly-owned oil and gas resources. Moreover, the terms upon which private enterprise obtains exploration and production rights determine the extent to which the government will be successful in collecting the economic rents.

In essence, the present allocation system operates in two stages. The first stage is generally represented by a petroleum and natural gas reservation $^{12}$ and the second by a petroleum and natural gas lease. The two stages are linked by a possibility of conversion from reservation to lease upon surrender to the Crown of 50 percent of the reservation area. Government revenue is obtained from lease rentals, production royalties and sales of surrendered areas. The entire process is governed by the Mines and Minerals Act ${ }^{13}$ and the regulations made thereunder.

\section{Petroleum and Natural Gas Reservations}

A reservation is initially obtained in unexplored areas by application to the Director of Minerals. ${ }^{14}$ There is a discretion to refuse an application but no mention is made in the Act or regulations of the factors to be considered in exercising this discretion. The practice has been to issue reservations to qualified applicants according to the time of filing. There is a fee of $\$ 250$ per reservation. ${ }^{15}$ The maximum area that may be contained in a reservation is 156 square miles, ${ }^{16}$ but there is no restriction placed upon the number of reservations that may be acquired by a single applicant.

The key to maintaining a reservation in force is the conducting of an exploration programme approved by the Minister. A reservation holder is required to submit a plan within 90 days describing the nature of the proposed examination. ${ }^{17}$ A number of reservations with a total area not exceeding 200,000 acres may be grouped for the purpose of this exploration programme. ${ }^{18}$ If the plan is acceptable to the Minister the initial term of four months is extended.19 Provided that satisfactory progress is

12 Except in "Block A", infra, at 156.

13 R.S.A. 1970, c.238, as amended by S.A. 1971, cs. 1, 30 and 96, S.A. 1972, c8. 67, 68, 91 and 119, S.A. 1973, cs. 34 and 94, and S.A. 1974, c8. 18 and 39.

14 Petroleum and Natural Gas Reservation Regulations, Alta. Reg. 251/62 (1962), as amended by Alta. Regs. $299 / 66$ (1966) and $396 / 68$ (1968); 8. 4.

is Id. at 8.5 .

16 Id. at $\mathrm{s}$. 6 . The area is $41 / 3$ townships, each comprising 36 sections.

17 Id. at 8. 11.

18 A group must consist of reservations held by the one person or company but there are no restrictions upon the location of reservations that may be included in a group: $I d$. at s. 15 .

19 The initial term is four months with two renewals of four months each. Then, there may be four further renewals of six months each upon satisfactory progress being made with exploration and upon payment of a fee of ten cents per acre for each renewal. Upon a representation to the Department that the nature of the terrain or the inaccessibility of the area under reservation or any other condition over which the holder has no control, has seriously retarded the performance of the exploration programme, the Minister may grant further extensions of up to two years upon such terms and conditions as he sees fit. Thereafter, where a well has been or is being drilled on lands in a reservation or group of reservations, six renewals of three months each may be obtained upon payment of the following fees:

(a) 10 cents per acre for the first renewal;

(b) 15 cents per acre for the second renewal

(c) 20 cents per acre for the third renewal:

(d) 25 cents per acre for each of the fourth, fifth and sixth renewals;

Id. at ss. 11-15. 
made with exploration, further renewals are available upon payment of stipulated fees so that a reservation may continue for as long as six and one-half years. ${ }^{20} \mathrm{~A}$ deposit is payable upon application for a reservation and if the exploration programme is not conducted in accordance with the approved plan this deposit is forfeited to the Crown. ${ }^{21}$ Upon termination of the reservation, the holder is required to furmish a report to the Department showing factual data obtained, information upon each hole for which a well licence was not required, and such further information as the Minister may require. ${ }^{22}$ To date it has not been the practice of the Department to require disclosure of raw data obtained from geological surveys.

A reservation conveys the exclusive right to drill a well or wells for petroleum and natural gas in the lands contained in the reservation and the right to produce these substances if found, but it does not convey the right to the produced substances, which remain the property of the Crown. ${ }^{23}$ Entitlement to petroleum and natural gas is acquired upon the granting of a lease.

\section{Petroleum and Natural Gas Leases}

The holder of a reservation does not have an absolute right to obtain a lease, but merely an exclusive right to apply for a lease or leases of the petroleum and natural gas rights in part of the lands contained in the reservation. ${ }^{24}$ This means that the Minister, who appears to have the right to issue leases under the Mines and Minerals Act, ${ }^{25}$ has a discretion to refuse an application for a lease. Nevertheless, the normal practice has been to grant lease applications provided that the applicant has fulfilled his obligations under the reservation. ${ }^{26}$

Restrictions are placed upon the selection of leases from a reservation. Leases may not exceed 50 per cent of the area of any township included in a reservation. ${ }^{27}$ The maximum area of a lease is nine sections if the lease area is square or eight sections if it is rectangular, in which case the length may not exceed four sections. The minimum area of a lease is a quarter-section. ${ }^{28}$ Lease areas must form a chequer-board pattern or be separated from one another by a corridor at least one mile

20 Id.

21 Id. at 8. 5. The deposit is $\$ 2,500$ for each 20,000 acres or part thereof.

22 Id. at 8. 17. Where a licence is obtained for the drilling of a well under the Oil and Gas Conservation Act, R.S.A. 1970 c. 267, disclosure of drilling information must be made to the Energy Resources Conservation Board, discussed infra.

23 Id. at 8. 9.

21 Id. at 8. 19. This distinction was important in a Queensland mining case, Cudgen Rutile (No. 2) Pty Ltd. et al. v. Chalk. There, the holder of an Authority to Prospect claimed to be entitled to the grant of a mining lease upon application, on the basis of a term of the authority which read:

Right to Acquire Mining Leases: Subject to due performance and observance of the provisions of the Acts and the terms, conditions, provisions and stipulations of this Authority to Prospect on the part of the Holder to be performed or observed, the Holder shall be entitled at any time and from time to time during the said period to apply for and have granted to him in priority to any other person or company, a min. ing lease for the minerals specified in clause 5 hereof under the Acts over any part of the lands comprised within this Authority to Prospect.

The Full Court of the Supreme Court of Queensland rejected this claim, and, its decision was subsequently upheld by the Judicial Committee of the Privy Council [1975] 2 W.L.R. 1.

2s The Act is not explicit in this regard: see 88. 9, 11-12, 113.

26 An exception arose in the case of a holder of a Block A permit in the Cypress Hills area. This permit extended into a provincial park and the permit holder, when applying for a lease, included areas within the park boundaries in his lease application. The application was not granted, and an agreement was negotiated with the permit holder whereby other areas were exchanged for the areas applied for inside the park boundaries: Communication with the Director of Minerals, Department of Mines and Minerals, Edmonton, 22 July, 1974.

27 Petroleum and Natural Gas Reservation Regulations, 1962, supra, n. 14 at s.26(1).

2s The Mines and Minerals Act, supra, n. 13, 88. 114, 115. 
wide. ${ }^{29}$ The areas of a reservation not selected for lease are surrendered and become Crown reserves. ${ }^{30}$

There is no necessity for discovery of petroleum or natural gas prior to an application for a lease. However, where a reservation holder has made a commercial discovery of oil he is required to apply for a lease or leases of the petroleum and natural gas rights in the lands containing the discovery well. ${ }^{31}$

A lease grants the right to the petroleum and natural gas that are the property of the Crown in the lease area subject to any exceptions expressed in the lease. ${ }^{32}$ The Mines and Minerals Act does not specify the nature of this right to petroleum and natural gas. To ascertain this it is necessary to turn to the lease document, the form of which is determined by the Minister. ${ }^{33}$ The granting clause of the current lease document reads as follows:

... in consideration of the rents and royalties hereinafter provided and subject to the terms and conditions hereinafter expressed, Her Majesty hereby grants unto the lessee in so far as the Crown has the right to grant the same the exclusive right to explore for, work, win and recover petroleum and natural gas within and under the lands more particularly described as follows ...., together with the right to dispose of the petroleum and natural gas recovered.

The nature of this disposition has not been subject to judicial determination. However, it is clear that the principle to be applied in interpreting the lease document is to ascertain the intention of the parties from the words in the document. ${ }^{34}$ There is no indication in the words chosen that a severance of oil and gas from the existing mineral estate is intended. Accordingly, the lessee does not acquire either a freehold or a leasehold estate in the oil and gas in the ground. Whether there is an intention to grant a lesser interest in land, such as a profit d prendre, is more difficult to answer. The Supreme Court of Canada has held, in the case of Berkheiser v. Berkheiser et al., ${ }^{35}$ that the freehold oil and gas lease generally in use in Western Canada does give a lessee an interest in land. However, the wording of the freehold oil and gas lease is significantly different from that of the Crown lease. The granting clause of the lease in the Berkheiser case read as follows:

The Lessor . . . doth hereby grant and lease . . . all the petroleum and natural gas... within, upon and under the lands... together with the exclusive right and privilege to explore, drill for, win, take, remove, store and dispose of, the leased substances....

The intention here to grant an interest in oil and gas in the ground is apparent. However, the omission from the Crown lease of any grant of

29 Petroleum and Natural Gas Reservation Regulation, 1962, supra, n. 14 at s. 26(4). A number of lease areas may be accumulated into a "concentration of leases" not larger than the maximum lease area, if desired: id. at 8. 26(3).

30 Id. at 8. 30 . However, a lease selection of less than the 50 per cent entitlement does not require surrender of all of the remaining reservation area. The reservation remains in force in respect of areas not covered by leases or Crown reserves established upon the initial lease selection: $i d$. at 8 . 19(2).

31 Id. at 8. 20.

32 The Mines and Minerals Act, supra, n. 13 at 8. 121.

33 Id. at 8. 122.

34 There are a number of cases in which a variety of interests in oil and gas have been claimed, where the courts have established the principle that the governing factor is the intention of the parties as demonstrated by the words used in their agreements; for example, see St. Lawrence Petroleum Ltd. et al. v. Bailey Selburn Oil and Gas Ltd. et al. (No. 2). [1963] S.C.R. 482, 45 W.W.R. 26, 41 D.L.R. (2d) 316; Bensette v. Reece (1969) 70 W.W.R. 705; Emerald Resources Ltd. v. Sterling Oil Properties Management Ltd. (1969) 3 D.L.R. (3d) 630; Saskatchewan Minerals v. Keyes [1972] S.C.R. 703, [1972] 2 W.W.R. 108, 23 D.L.R. (3d) 573.

3s [1957] S.C.R. 387, 7 D.L.R. (2d) 721.

36 Clause 12-19, lease document (Form 160-A). 
these substances until after they are produced suggests that the Crown lessee has no interest in land but merely a licence to conduct specified operations relating to Crown oil and gas.

A further question that arises is whether the Crown petroleum and natural gas lease amounts to a contract enforceable against the Crown. The lease document is drawn in the form of a contract and legal consideration passing from the lessee to the Crown is not in doubt. A number of covenants are expressed to be between the lessee and the Crown, ${ }^{36}$ but these impose obligations upon the lessee only and not upon the Crown. The sole source of obligations undertaken by the Crown appears to be the granting clause, quoted above. Moreover, there is the doctrine that the Crown may not contract so as to fetter its freedom of executive action in circumstances where public policy demands the retention of this freedom. ${ }^{37}$ The scope of this doctrine is uncertain and there is no apparent example of its application to the allocation of private rights over Crown resources. ${ }^{38}$ Nevertheless, it is open to argument that the public interest requires freedom in executive action in the management of Crown oil and gas resources.

In any event, the covenants contained in the Crown lease document demonstrate a clear intention on the part of the Crown to retain the right to alter the terms and conditions of the lease by future, unilateral action. ${ }^{39}$ The first covenant reads as follows:

1. The lessee shall comply with the provisions of The Mines and Minerals Act and any Act passed in substitution therefor, and any regulations that at any time may be made under the authority of the said Acts, and all such provisions and regulations that prescribe, relate to or affect the rights and obligations of lessees of petroleum and natural gas rights, the property of the Crown, shall be deemed to be incorporated into this lease and shall bind the lessee in the same manner and to the same extent as if the same were set out herein as covenants on the part of the lessee. Each and every provision or regulation hereafter made shall be deemed to be incorporated into this lease and shall bind the lessee as and from the date it comes into force, but in the event of conflict between any regulation hereafter made and any regulation previously made the regulation last made shall prevail.

This achieves the result that the future executive action of the Crown is not fettered irrespective of the nature of the lessee's interest under the lease. ${ }^{40}$

The term of a lease is ten years. ${ }^{41}$ There is no general requirement that the lessee carry out exploration or development work during this period. However, an inducement to explore is contained in the renewal

97 The doctrine derives its principal support from the case of Rederiaktiebolaget Amphitrite v. The King [1921] 3 K.B. 500.

38 For an excellent discussion of the background to and limitations upon the doctrine, see Turpin, Government Contracts (1972) at 19-36.

39 For a detailed discussion, see Thompson, Sovereignty and Natural Resources-A Study of Canadian Petroleum Legislation, (1967) 1 Val. U.L. Rev. 284, reprinted in (1970) 4 U.B.C.L. Rev. (No. 2) 161. This right to alter the terms and conditions of the lease may be inconsistent with the formation of an ordinary contract. The courts usually require that both parties demonstrate an intention to be bound by the terms of their arrangement before a contract is formed: Chitty on Contracts, (23rd ed. 1968) at para. 88; Cheshire and Fifoot, The Law of Contract, (8th ed. 1972) at 96-98; Treitel, The Law of Contract, (3rd ed. 1970) at 124-5; Anson, Law of Contract, (23rd ed. 1969) at 31-34. However, the requirement of this intention has been disputed: Williston. The Law of Contract, (2nd ed. 1957) at s. 21. Moreover, it is possible that a court would find an intention to enter into a binding agreement despite the ability of one party to alter terms at will.

40 In recent years lessees have accepted changes made to lease terms and conditions without resort to court ac. tion. Perhaps the best example of this is the removal, in 1972, of the $162 / 3$ per cent ceiling upon royalty rates contained in both the Mines and Minerals Act and many lease documents. The Mines and Minerals Amendment Act, S.A. 1972, c.68, s.3, struck out the section (s.143) in the previous Act stipulating such a ceiling, and a further amendment, S.A. 1973, c.94, 8.4, inserted 8. 142.1 which provides expressly that any maximum royalty provision in a lease document is void.

"The Mines and Minerals Act, supra, n. 13 at s. 125. 
provisions. Upon expiry of the primary term, a lease continues only as to that part of the lease area within the spacing unit for each producing well. 42

After the fifth year of the initial lease term the Minister may give the holder of a lease upon which there is no producing well a notice requiring the holder to commence drilling operations within one year. Failure to comply with such a notice may result in cancellation of the lease unless the Minister grants an extension of time for compliance and the lessee pays a delay penalty. ${ }^{43}$ In the case of leases granted since 1962 , which have an initial term of ten years, the Department has not found it necessary to issue drilling notices in recent years as the level of exploration has been generally satisfactory. The Department has also taken into account in refraining from issuing drilling notices, factors such as the current shortage of drill pipe, rigs and specialized labour. There has been no attempt to use the provision to promote a turnover of acreage before the expiry of the initial lease term. In the case of leases acquired before 1962, which have an initial term of 21 years, drilling notices have been issued automatically to take effect at the end of the tenth year of the term. However, such notices have never been applied on a discretionary basis to individual leases, but always in furtherance of a declared policy generally applicable to all leases of a specified age.44

The consideration paid in respect of a lease selected from a reservation consists of a rental and a royalty. The annual rental is one dollar per acre of land under lease. 45 Where a well is a gas producer or a lease is within a natural gas field the Minister has a discretion to reduce the rental to 50 cents per acre, or if there is no market available for the gas, to 25 cents per acre.46 This discretion is usually exercised in a lessee's favour where the Minister is satisfied that the lessee has carried out development drilling in the lease area sufficient to delineate the gas accumulation. ${ }^{47}$

The Alberta government recently introduced new royalty rates for both petroleum and natural gas. ${ }^{48}$ Previously, the petroleum royalty was calculated on a sliding-scale basis, rising from 5 per cent to 25 per cent with increasing rate of production from each well. The average rate prior to the adoption of the new scale was 22.8 per cent. ${ }^{49}$ The new scale retained the old as a basic royalty and added a supplementary royalty which also varies with rate of production, and is calculated upon the

12 Id. at s. 126. The normal spacing unit for a producing well is 160 acres. Where the spacing unit for a well is less than one section the lease continues as to one section: $i d$. at. If a well is being drilled upon expiry of the primary term the lease continues as to the spacing unit until completion of the well: id. at s8. 130-132.

43 Id. at 88. 125.1-125.5.

(a) $\$ 1$ per acre for the first year.

(b) $\$ 3$ per acre for the second year,

(c) $\$ 5$ per acre for the third year,

(d) $\$ 9$ per acre for the fourth year.

it Communication with the Director of Minerals, supra, n. 26.

15 The Mines and Minerals Act, supra, n. 13 at 8. 113. Fifty per cent of expenditures incurred in geological or geophysical exploration or in the drilling of wells on lands contained in the reservation may be credited against the first year's rental for any leases acquired out of the reservation: Petroleum and Natural Gas Reservation Regulations, supra, n. 14 at 8. 22.

46 The Mines and Minerals Act, supra, n. 13 at s. 124 . Before a reduction becomes effective, however, the Minister may require a lessee to drill a well to search for petroleum. While a reduction is in force, the Lieutenant Governor in Council may order the drilling of wells for natural gas.

47 Communication with the Director of Minerals, supra, n. 26.

As Petroleum Royalty Regulations, Alta. Reg. 93/74, taking effect on April 1, 1974; Natural Gas Royalty Regulations, Alta. Reg. 16/74, taking effect on January 1, 1974. The government acted pursuant to powers given by The Mines and Minerals Act, supra, n. 13 at 8s. 31,142 and 145.

19 Statement to the Legislative Assembly by the Hon. Bill Dickie, Minister of Mines and Minerals, March 28, 1974. 
difference between the current price of crude oil and the price prevailing on March 31, 1974. The supplementary royalty is considerably higher for "old" oil than for "new" oil.50 For both old and new oil, though, the new royalty scales are derived by application of a complex formula which effects uniform increases in the previous royalty scales. This formula is set out in Table 1. In the case of old oil, the increase is by a factor of

TABLE 1

The royalty for a month shall be calculated in accordance with the following equation:

$$
R=S+k S \frac{(A-B)}{A}
$$

Where $\quad \mathbf{R}$ is the royalty payable, in barrels;

$\mathbf{S}$ is the number of barrels, determined in accordance with the Table in this Schedule;

$\mathrm{k}$ is the royalty factor for the month that is applicable to the crude oil from the well;

$A$ is the par price of crude oil for the month;

$B$ is the select price of crude oil for the month.

\section{TABLE}

"Barrel" means 34.9723 gallons

Monthly

Production

in Barrels

0 to 1200

Portion of Crown Royalty Payable for the Month in Barrels The number of barrels determined by dividing the barrels produced by 120 and adding 5 to the quotient, then multiplying by the barrels produced and dividing by 100 .

1200 and over 180 barrels plus one-fourth of the number of barrels produced in excess of 1200 barrels.

SOURCE: $\quad$ Petroleum Royalty Regulations, Alta. Reg. 93/74 (1974), Schedule B.

1.7732 so that the scale now rises from 8.866 per cent to 44.33 per cent with increasing rate of production from each well. The average rate when weighted according to existing production rates is 40.429 per cent. In the case of new oil, the increase is by a factor of 1.222 so that the scale now rises from 6.11 per cent to 30.55 per cent with increasing rate of production from each well. If new oil is produced at the same rate as old, the average royalty rate for new oil will be 27.864 per cent. The different scales are depicted in Figure 1.

The new gas royalty is calculated on a sliding scale basis, rising not with rate of production but with selling price. Different schedules apply to "old" and to "new" gas. These are set out in Table 2. For old gas the royalty rises from 22 per cent when the wellhead price is 26 cents or less per thousand cubic feet to 48.68 per cent when the wellhead price is $\$ 1.20$ per thousand cubic feet. For new gas, the rates are 22 per cent for 26 cents gas and 31.66 per cent for $\$ 1.20$ gas. ${ }^{51}$ The scales are depicted in Figure 2. Where the Minister is satisfied that the actual selling price of any gas is less than the fair value thereof, he is required to direct that

\footnotetext{
so The average supplementary royalty rate is 65 per cent (of the difference between current and March 1974 prices) for "old" oil; but only 35 per cent for "new" oil. However, these are only average figures. The distinction between "old" and "new" oil is based upon the date of discovery of a pool or upon the date of increase in reserves obtained from implementation of an enhanced recovery scheme: Petroleum Royalty Regulations, supra, n. 49 at 8.2 
FIGURE 1: PETROLEUM ROYALTY SCALES

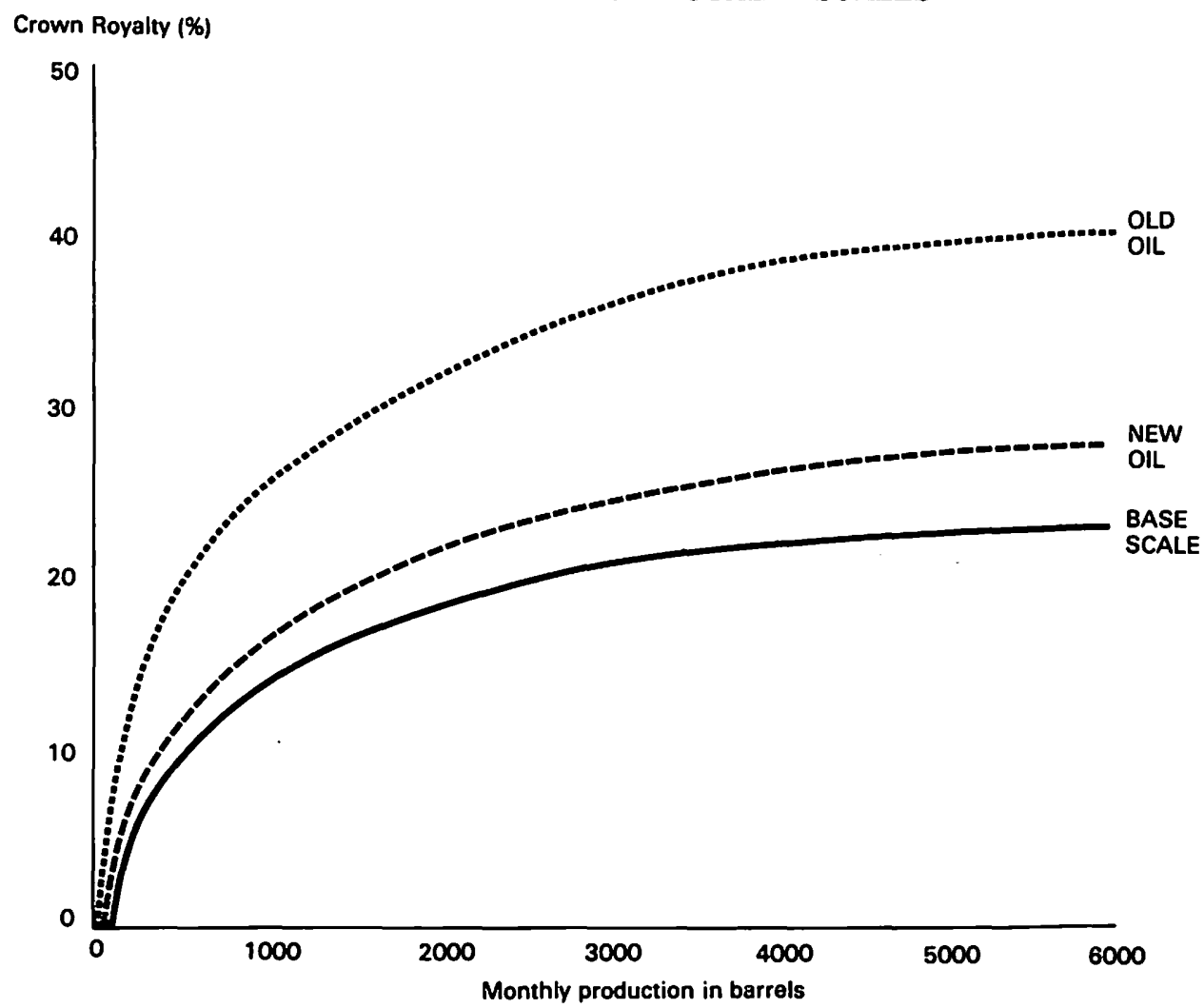

the fair value be used instead of the actual selling price for the purpose of calculating royalty. ${ }^{52}$ On the other hand, when the royalty rate is such as to impair the economic feasibility of production of gas from any well or pool, the Lieutenant-Governor in Council may reduce the applicable royalty rate. ${ }^{53}$

\section{Block $A$}

The two-stage system of reservations and leases does not apply in all parts of Alberta. In Block A, townships 1 to 64 west of the fourth meridian, a more generous system has been devised to stimulate waning interest in exploration. The first stage of this system is represented by a permit. The important distinctions between a permit and a reservation are, first, the holder of a permit is required to pay a rental which is refunded in part when the drilling of a well is commenced 54 and, second. ly, provided that a well has been drilled to test for petroleum or natural gas, the holder of a permit may apply for a lease of the petroleum and natural gas rights in all of the permit lands without surrender of any Crown reserves. ${ }^{55}$ The maximum area of a permit is 36 sections..$^{56}$ The

32 Id. at $8.2(2)$.

53 Id. at 8. 5 .

54 Petroleum and Natural Gas Permit Regulations, Alta. Reg. 250/62 (1962), ss. 7, 11. The rental for each six months period is 50 cents per acre and refunds are at the rate of 30 cents, 20 cents or 10 cents per acre depen. ding on whether the well is commenced during the first, second, or third six-month period, respectively.

ss Id. at 8. 6.

so Id. at s. 8 . 
1. In this Schedule,

\section{TABLE 2 \\ CROWN ROYALTY \\ NATURAL GAS AND RESIDUE GAS}

(a) " $F$ " means the average selling price per Mcf for the month of natural gas or residue gas;

(b) "R\%" means the Crown's royalty share expressed as a percentage of the natural gas or residue gas.

2. Where the selling price of natural gas or residue gas on which royalty is payable is less than or equal to 26 cents per Mcf, the royalty payable thereon is 22 per cent of the natural gas or residue gas.

3. Subject to $\mathrm{s}$. 4 of this Schedule, where the selling price of natural gas or residue gas on which royalty is payable is greater than 26 cents per $M c f$ and within a range of selling price in the column in the following table headed "Selling Price", the royalty payable on the natural gas or residue gas is the percentage thereof computed in accordance with the equation shown opposite that range in the column headed "Royalty Percentage":

\section{Selling Price}

(in cents per Mcf)

$\begin{array}{ll}26 \text { to } 28 & R \%=\frac{572+25(F-26)}{F} \\ 28 \text { to } 30 & R \%=\frac{622+30(F-28)}{F} \\ 30 \text { to } 32 & R \%=\frac{682+35(F-30)}{F} \\ 32 \text { to } 34 & R \%=\frac{752+40(F-32)}{F} \\ 34 \text { to } 36 & R \%=\frac{832+45(F-34)}{F} \\ 36 \text { to } 72 & R \%=\frac{922+50(F-36)}{F} \\ \text { over } 72 & R \%=\frac{2722+65(F-72)}{F}\end{array}$

Royalty Percentage

$$
\begin{aligned}
& R \%=\frac{572+25(F-26)}{F} \\
& R \%=\frac{622+30(F-28)}{F} \\
& R \%=\frac{682+35(F-30)}{F} \\
& R \%=\frac{752+40(F-32)}{F} \\
& R \%=\frac{832+45(F-34)}{F} \\
& R \%=\frac{922+50(F-36)}{F} \\
& R \%=\frac{2722+65(F-72)}{F}
\end{aligned}
$$

term is six months plus three extensions of six months each, with two further extensions of six months each if the drilling of a well is in progress. 57

\section{Natural Gas License and Lease}

Special provision is made for the case where gas is discovered in a reservation or permit area. The holder may apply for a licence of the natural gas rights in the zone or zones containing the gas. ${ }^{58} \mathrm{~A}$ licence gives the right to drill wells for gas into the specified formations and to produce gas when found. ${ }^{59}$ In fact, the holder is required to drill at least two such wells. ${ }^{60}$ Before a licence expires, ${ }^{61}$ the holder has the exclusive right to apply for a lease or leases of the rights in the natural gas indicated by drilling in the licence zones. ${ }^{62}$ The conditions upon which a

57 Id. at $88,9-10$.

s8 Natural Gas Licence Regulations, Alta. Reg. 297/62 (1962) as amended by Alta. Reg. $392 / 66$ (1966) at 8. 4. The maximum licence area is 36 sections: id. at 8.6 .

39 Id. at 8. 14. Entitlement to gas when produced is not specified but presumably remains with the Crown.

60 Id. at 8. 10. Cf. The Mines and Minorals Act, supra, n. 13 at s. 154.

6) The term of a licence is six months, plus five extensions of six months each provided that satisfactory progress reports are filed and the rental of five cents per acre is paid for each six months period: Natural Gas Licence Regulations, 1962, supra, n, 58 at 8.9.

62 Id. at 8. 17. The Minister may grant a natural gas lease only in specified circumstances, namely

(a) if the natural $\mathrm{gas}$ is required in the operation of a natural gas utility, or

(b) if the area is required to complete a spacing unit for a productive natural gas well, or

(c) the area is required for a unit operation. The Mines and Minerals Act, supra, n. 13 at 8. 149. 


\section{TABLE 2 (Cont'd.)}

\section{CROWN ROYALTY}

\section{NATURAL GAS AND RESIDUE GAS}

4. (1) In this section, "new Gas well" means a well

(a) for which the well licence under The Oil and Gas Conservation Act was issued after January 1, 1974, and

(b) that in the opinion of the Minister obtains natural gas from a pool initially discovered after January 1, 1974.

(2) Section 3 of this Schedule does not apply to natural gas obtained from new gas wells or to residue gas obtained by processing that natural gas.

(3) Subsections (4) and (5) apply only to natural gas obtained from new gas wells and to residue gas obtained by processing that natural gas.

(4) Where the selling price of natural gas or residue gas on which royalty is payable is greater than 26 cents per Mcf and within a range of selling price in the column in the following table headed "Selling Price", the royalty payable on the natural gas or residue gas is the percentage thereof computed in accordance with the equation shown opposite that range in the column headed "Royalty Percentage":

Selling Price

(in cents per Mcf)

26 to 28

28 to 30

30 to 32

32 to 34

34 to 36

over 36

\section{Royalty Percentage}

$\mathrm{R} \%=\frac{572+24(\mathrm{~F}-26)}{\mathrm{F}}$

$R \%=\frac{620+26(\mathrm{~F} \cdot 28)}{\mathrm{F}}$

$R \%=672+28(F-30)$

$\mathrm{F}$

$R \%=\underline{728+30(F-32)}$

$F$

$\mathrm{R} \%=788+33(\mathrm{~F} \cdot 34)$

$\mathrm{F}$

$R \%=854+35(\mathrm{~F}-36)$

F

SOURCE: Natural gas Royalty Regulations, Alta. Reg. 16/74 (1974), Schedule 1.

natural gas lease are granted are less onerous than those contained in a petroleum and natural gas lease. ${ }^{63}$

\section{Crown Reserves}

Crown reserves are available for disposition upon such terms and conditions as may be prescribed by the Lieutenant-Governor in Council. These may include payment to the Crown of a share of the products, or of an overriding royalty, or of any other consideration in addition to the normal royalty on oil and gas. ${ }^{64}$

63 The area acquired under lease may depend upon the depth of the gas procuding zones. Maximum areas are (a) six sections for a well depth of up to 3,000 feet,

(b) eight sections for a well depth of between 3,000 and 6,000 feet,

(c) ten sections for a well depth exceeding 6,000 feet.

However, if the holder of a license has delineated a natural gas field by the drilling of adequately spaced wells the Minister may grant a natural gas lease for the zone or zones covering the entire field: Natural Gas License Regulations, 1962, supra, n. 58 at 8 . 17. The term of a natural gas lease is 21 years renewable for further periods of 21 years each so long as the area is capable of commercial production: The Mines and Minerals Act, supro, n. 13 at s. 150. The annual rental is 331/3 cents per acre and if a market for the gas is not available may be reduced to 10 cents per acre: $i d$. at 8 . 151 . Royalty is payable on the same basis as under a petroleum and natural gas lease: id. at 8. 142. Upon discovery of oil in a zone subject to a natural gas license or lease, the holder is entitled to acquire a petroleum and natural gas lease for the zone covering the quartersection in which the discovery was made, upon surrender of an area equal to three times the area of the petroleum and natural gas lease acquired: id. at 8. 156; Natural Gas License Regulations, 1962, supra, n. 58 at s. 21. Upon surrender of a natural gas license or lease, the formations contained therein may be returned to the reservation or permit from which they were excised or any petroleum and natural gas leases subsequently acquired therefrom: Natural Gas Licence Regulations, 1962, supra, n. 58 at 8. 22.

64 The Mines and Minerals Act, supra,'n. 13 at s. 112. 
Crown Royalty (\%)

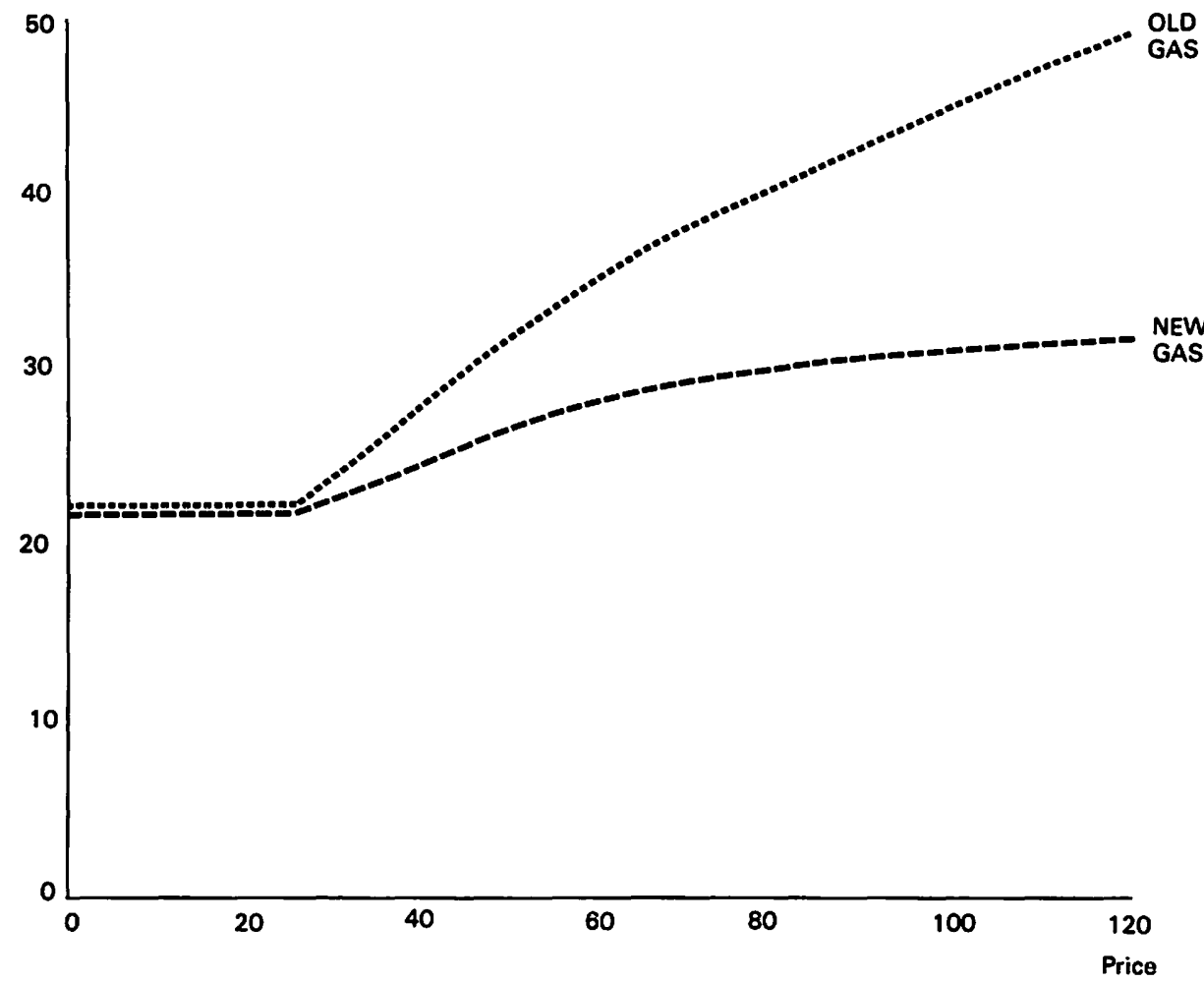

A number of different methods have been used in practice for allocating rights over Crown reserves, depending upon the history of the acreage prior to its surrender to the Crown. If a discovery of oil has been made upon a reservation prior to the lease selection and surrender of Crown reserves, the Department will usually offer the Crown reserves for sale in the form of petroleum and natural gas leases. If a discovery of gas has been made, the offer is likely to be made in the form of Crown reserve natural gas licenses. ${ }^{65}$ Where the holder of a reservation has selected leases and has surrendered Crown reserves without having drilled a well in the reservation area, the Department generally offers a special form of title known as a Crown reserve drilling reservation. This allows further exploration in the area before leases are obtained.66

The Department seldom offers Crown reserves for sale in the absence of a request from industry. An exception to this policy occurs when there is a possibility of drainage of oil or gas by producing wells on an adjoining lease area. Normally, the holder of a reservation who has selected leases from within the reservation area will request posting of the surrendered Crown reserves within a year of going to lease, as this

6s Crown Reserve Natural Gas Licence Regulations, Alta. Reg. 308/62 (1962), as amended by Alta. Reg. 230/65 (1965). The terms and conditions of such a license, and the rights acquired thereunder, are identical with those of an ordinary natural gas license.

es Crown Reserve Drilling Reservation Regulations, Alta. Reg. 28462 (1962). The holder of a Crown reserve drilling reservation is required to commence the drilling of a well within one year of the date of issue, and if that well does not indicate a commercial deposit of oil must drill a further well in the area. The holder then has the right to apply for a petroleum and natural gas lease in respect of an area not greater than that specified in the notice offering the reservation, usually one-quarter of the total area of the Crown reserve drilling reservation. In other respects a Crown reserve drilling reservation is similar to an ordinary reservation. 
enables him to bid for the Crown reserves with information obtained from previous drilling operations while this information remains confidential. ${ }^{67}$ It is Department practice to offer Crown reserves for sale upon receipt of such a request. ${ }^{68}$

An invitation to bid for Crown reserves is advertised. Sealed bids are invariably required. The type of consideration is a cash bonus, in addition to the ordinary rental and royalty payments. Sliding bids may be submitted as long as they demonstrate a clear choice on the part of the person making the bid and do not amount to an attempt to rebid in the event of initial failure. Considerable flexibility is allowed in the construction of such bids, which are frequently submitted by both majors and independents. ${ }^{69}$

The Lieutenant-Governor in Council may reject bids in his discretion. In practice, a bid of less than $\$ 10$ per acre will not be accepted for a petroleum and natural gas lease on Crown reserves. Furthermore, the Department attempts to assess the value of parcels offered for bid where information is available for this purpose. Such information will usually consist of bids received for comparable tracts or the results of drilling in adjoining areas. The results of geological surveys are not disclosed to the Department and so are not available. The assessed value of a tract and the number of bids received for it are both taken into account in deciding whether or not to accept the highest bid received. ${ }^{70}$

\section{Critique}

The overwhelming feature of the Alberta system for allocation of Crown oil and gas rights is its complexity. On the one hand, this is attributable to the use of a two-stage process. Not only do two types of rights have to be defined, but also it becomes necessary to make rules governing conversion from one stage to another and surrender of areas to the Crown. These conversion and surrender provisions accentuate information spillovers, whereby a person conducting exploration operations does not benefit fully from the information generated by his operations. ${ }^{71}$ They also add to the difficulties encountered in reaching agreement for unit development of a pool or field. ${ }^{72}$ It is argued that a two-stage process encourages exploration, but there appears to be no reason why this must necessarily be so; nor is it clear that an incentive is required for all types of exploration or that a two-stage rights structure provides the best incentive available. On the other hand, considerable complexity results from the special provisions made for gas under natural gas licences and leases. In the past these were justified by

67 For a discussion of the disclosure provisions affecting drilling information and periods of confidentially, see infra at 175 .

6o Communication with the Director of Minerals, supra, n. 26.

69 Id. An example of a sliding bid is as follows if a company is interested in parcels 1,4 and 7 , it may submit a bid in the following terms:

First choice-parcel 1 \$x $\begin{array}{ll}\text { parcel } 4 & \$ x \cdot 5 \\ \text { parcel } & \$ x-6\end{array}$

If I am unsuccessful in obtaining all three parcels with my first choice, please disregard this and consider my second alternative

Second choice-parcel 1

If 1 am unsuccessful in obtaining both parcels 1 and 4 with my second choice, please disregard this and consider my third alternative:

Third choice-parcel 1 \$ 5 .

$70 \mathrm{Id}$.

71 Infre at 170.

72 Infra at 188. 
reference to the difficulties encountered in marketing gas, but now the situation has changed completely with high prices and strong demand for all available gas resources. Therefore, much of the complexity of the Alberta system of rights allocation appears to serve no useful end at this time.

The system is also open to criticism on efficiency grounds. Both the oil and the gas royalties are "gross" royalties, in that they are calculated by reference to wellhead volume and price without any allowance for costs of discovery, development or production. A gross royalty may cause economic inefficiency through shut-down of a producing well when the marginal value of production is no longer sufficient to meet both royalty and operating costs, although it still exceeds operating costs alone. In the case of oil this possibility is diminished by the sliding scale nature of the royalty, the marginal rate of which falls with declining production rates. ${ }^{73}$ In the case of gas it may presumably be avoided entirely by exercise of the Lieutenant-Governor in Council's discretion to reduce royalty rates when economic conditions require it. ${ }^{74}$

However, imposition of gross royalties at high marginal rates affects not only the abandonment of wells but also the level of investment in production facilities during the life of a producing field. Royalty payments, from the point of view of the producer, are either deducted from marginal revenue or added to marginal cost. Either way, a wedge is driven between social and private marginal revenues and costs. The marginal pool from society's point of view is outside the producer's extensive margin ${ }^{75}$ so that, in the absence of government subsidy, the pool will not be developed. More significant, perhaps, in view of Alberta's maturity as an oil producing province, is the similar distortion at the intensive margin. ${ }^{76}$ This results in under-investment in both initial production facilities and enhanced recovery schemes, as compared with the situation where gross royalties are not applied.

The royalty for oil is calculated according to monthly production per well rather than per acre of land drained. ${ }^{77}$ This provides an incentive for the drilling of more wells than would be required for optimum production from a reservoir in those cases where such drilling will achieve a reduction in the effective marginal royalty rate. Such a reduction will be possible only where production from a well falls below 1200 barrels per month, since at higher production rates the marginal royalty rate is constant. ${ }^{78}$ Thus, this incentive for over-drilling may not be large.

A number of provisions of the allocation system affect the timing of investment in exploration and production. Firstly, the method of issuing reservations over unexplored areas on the basis of filing, or "first-come, first-served",79 gives Crown oil and gas rights in these areas the characteristic of common property resources. Operators are forced to take up reservations before they otherwise would, since failure to do so

73 Supra, at 156.

74 Natural Gas Royalty Regulations, supre, n. 48 at 8. 5.

75 The producer's extensive margin is the point at which his marginal costs of investing in the undeveloped pool are just equal to his marginal revenues therefrom, that is to say, the point at which it becomes profitable to develop this pool.

${ }_{78}$ The intensive margin is the point at which the marginal cost to the producer of further investment in a partially developed pool is equal to the marginal revenue derived from that further investment.

77 Supra, at 154. This may be compared with the additional royalty scale applicable to federal lands under the Canada Oil and Gas Land Regulations, SOR/61-253 (1961)95 Canada Gazette (Part II) 805, June 28, 1961.

78 Supra, at 156.

79 Supra, at 150. 
may well result in loss of the opportunity to acquire any rights at all. This free-entry system encourages the great "land plays" that have been a mark of oil and gas exploration in Alberta. Secondly, once a reservation has been acquired, work commitments must be undertaken in order to maintain the reservation in force. ${ }^{80}$ This also tends to cause an acceleration of investment in exploration. Thirdly, the restrictions placed upon renewal of a lease beyond the initial term of ten years ${ }^{81}$ may affect the timing of investment in both exploration and development, as may the issue of drilling notices to lessees after the fifth year of the lease term. ${ }^{82}$ Finally, the imposition of lease rentals at a fixed rate per acre provides an incentive to speed up the development of a lease area. All these factors operate in the same direction, encouraging earlier investment in exploration and development than private enterprise would otherwise be willing to undertake. Whether or not this involves inefficiency depends, of course, upon whether the rate of investment chosen by private enterprise in the absence of these provisions would be slower than Alberta's efficient rate. ${ }^{84} \mathrm{~A}$ number of situations could give rise to this. One would be substantial monopoly control of production. A second would be better foresight on the part of government than industry of future price changes for oil and gas. A third would be the use by private enterprise of a discount rate lower than the social discount rate for Alberta. However, none of these appears very likely. The threat of monopoly control has always been less serious at the production stage than at the later stages of transportation and refining. The recent dramatic price changes were foreseen by neither government nor industry. It is generally assumed that, because of tax distortions, the private discount rate is higher than the social rate in developed economies. Thus, it seems that the provisions in the allocation system encouraging earlier investment in both exploration and production involve a social cost to Alberta.

Government revenues from oil and gas production in Alberta are substantial. The sources of these revenues are rentals, royalties and Crown reserve sales. A detailed analysis of government revenues, by year and source, is contained in Table 3 . Rentals were important in the past as they gave an element of stability to revenues when markets for oil and gas were uncertain. Their significance has declined with changes in market conditions, and rates have not been revised for several years. Royalties now account for a clear majority of government revenues from oil and gas, reflecting Alberta's position as a developed petroleum province. In 1973, royalties represented over 72 per cent of total revenue, whereas prior to 1970 , they traditionally provided less than 50 per cent. This growth in importance of royalties has been accompanied by a decline in revenues raised by Crown reserve sales. In 1959 , these sales provided more than 50 per cent of government oil and gas revenues and in 1965 , this figure was still 48 per cent, but by 1973 it had fallen to below 10 per cent and was of less significance than rental revenue.

supra, at 150.

al Supra, at 153.

22 Supra, at 153.

23 Supra, at 154.

B4 Welfare economics shows that a perfectly competitive market system achieves the optimum allocation of resources among different uses, as well as between present and future. Lerner, The Economics of Control (1944); Bator, The Simple Analytics of Welfare Maximization, American Economic Review, March, 1957 at 22 59. However, the conditions for the establishment of a perfectly competitive market system are stringent: many buyers and sellers, absence of distorting taxes, perfect capital markets and perfect knowledge of present and future. 


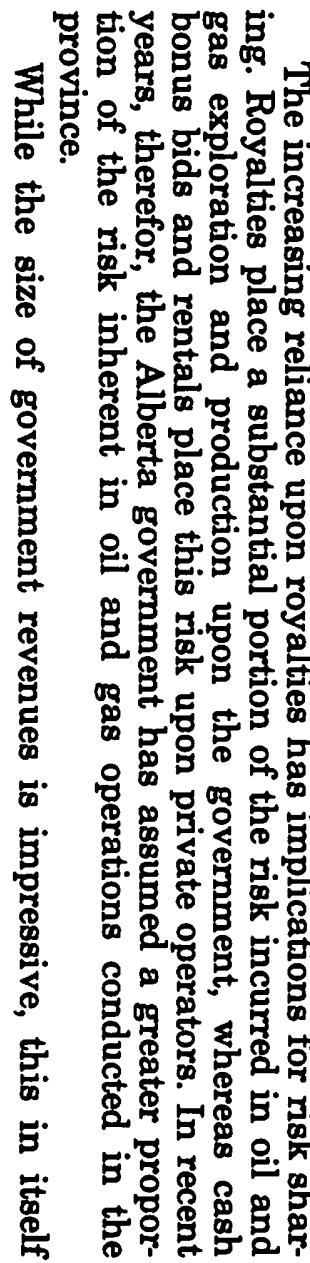

TABLE 3

REVENUES: CROWN OIL AND GAS

\begin{tabular}{|c|c|c|c|c|c|c|}
\hline Crown & $\begin{array}{c}1947 \\
\text { to } \\
1956 \\
\end{array}$ & 1957 & 1958 & 1959 & 1960 & 1961 \\
\hline $\begin{array}{l}\text { Sales of } \\
\text { Crown Reserves }\end{array}$ & & & In Dollars & & & \\
\hline $\begin{array}{l}\text { P. \& N.G. Leases } \\
\text { P. \& N.G. Reservations } \\
\text { Drilling Reservations } \\
\text { N.G. Licences } \\
\text { N.G. Leases } \\
\text { TOTAL } \\
\end{array}$ & $\begin{array}{r}243,002,562 \\
53,265,271 \\
19,362,200 \\
3,380,124 \\
278,326 \\
319,288,483 \\
\end{array}$ & $\begin{array}{r}40,365,608 \\
15,621,854 \\
11,503,167 \\
713,763 \\
15,379 \\
68,219,771 \\
\end{array}$ & $\begin{array}{r}26,943,761 \\
10,680,718 \\
11,881,522 \\
996,145 \\
579,501 \\
51,081,647 \\
\end{array}$ & $\begin{array}{r}50,202,900 \\
5,777,783 \\
14,240,583 \\
1,303,873 \\
302,603 \\
71,827,742 \\
\end{array}$ & $\begin{array}{r}39,563,522 \\
1,468,561 \\
9,227,304 \\
3,649,160 \\
55,533 \\
53,964,080 \\
\end{array}$ & $\begin{array}{r}31,420,897 \\
478,657 \\
10,660,447 \\
1,164,595 \\
906,560 \\
44,631,156 \\
\end{array}$ \\
\hline \multicolumn{7}{|l|}{ Rentals } \\
\hline $\begin{array}{l}\text { P. \& N.G. } \\
\text { Natural Gas } \\
\text { TOTAL }\end{array}$ & $\begin{array}{r}138,216,227 \\
1,240,939 \\
139,457,166\end{array}$ & $\begin{array}{r}29,767,283 \\
334,316 \\
30,101,599\end{array}$ & $\begin{array}{r}29,676,306 \\
387,656 \\
30,063,962 \\
\end{array}$ & $\begin{array}{r}31,664,033 \\
589,594 \\
32,253,627 \\
\end{array}$ & $\begin{array}{r}31,360,182 \\
631,694 \\
31,991,876 \\
\end{array}$ & $\begin{array}{r}30,140,780 \\
720,124 \\
30,860,904 \\
\end{array}$ \\
\hline $\begin{array}{l}\text { Royalties } \\
\text { Oil } \\
\text { Gas } \\
\text { Gas Products } \\
\text { TOTAL } \\
\end{array}$ & $\begin{array}{r}128,179,149 \\
2,254,466 \\
248,690 \\
130,682,305 \\
\end{array}$ & $\begin{array}{r}35,384,313 \\
583,460 \\
70,718 \\
36,038,491 \\
\end{array}$ & $\begin{array}{r}23,235,087 \\
994,893 \\
64,771 \\
24,294,751 \\
\end{array}$ & $\begin{array}{r}25,981,835 \\
1,291,029 \\
58,382 \\
27,331,246 \\
\end{array}$ & $\begin{array}{r}25,612,872 \\
1,782,699 \\
144,171 \\
27,539,742 \\
\end{array}$ & $\begin{array}{r}32,062,246 \\
2,537,158 \\
832,140 \\
35,431,544 \\
\end{array}$ \\
\hline REVENUE TOTALS & $589,427,954$ & $134,359,861$ & $105,440,360$ & $131,412,615$ & $113,495,698$ & $110,923,604$ \\
\hline
\end{tabular}




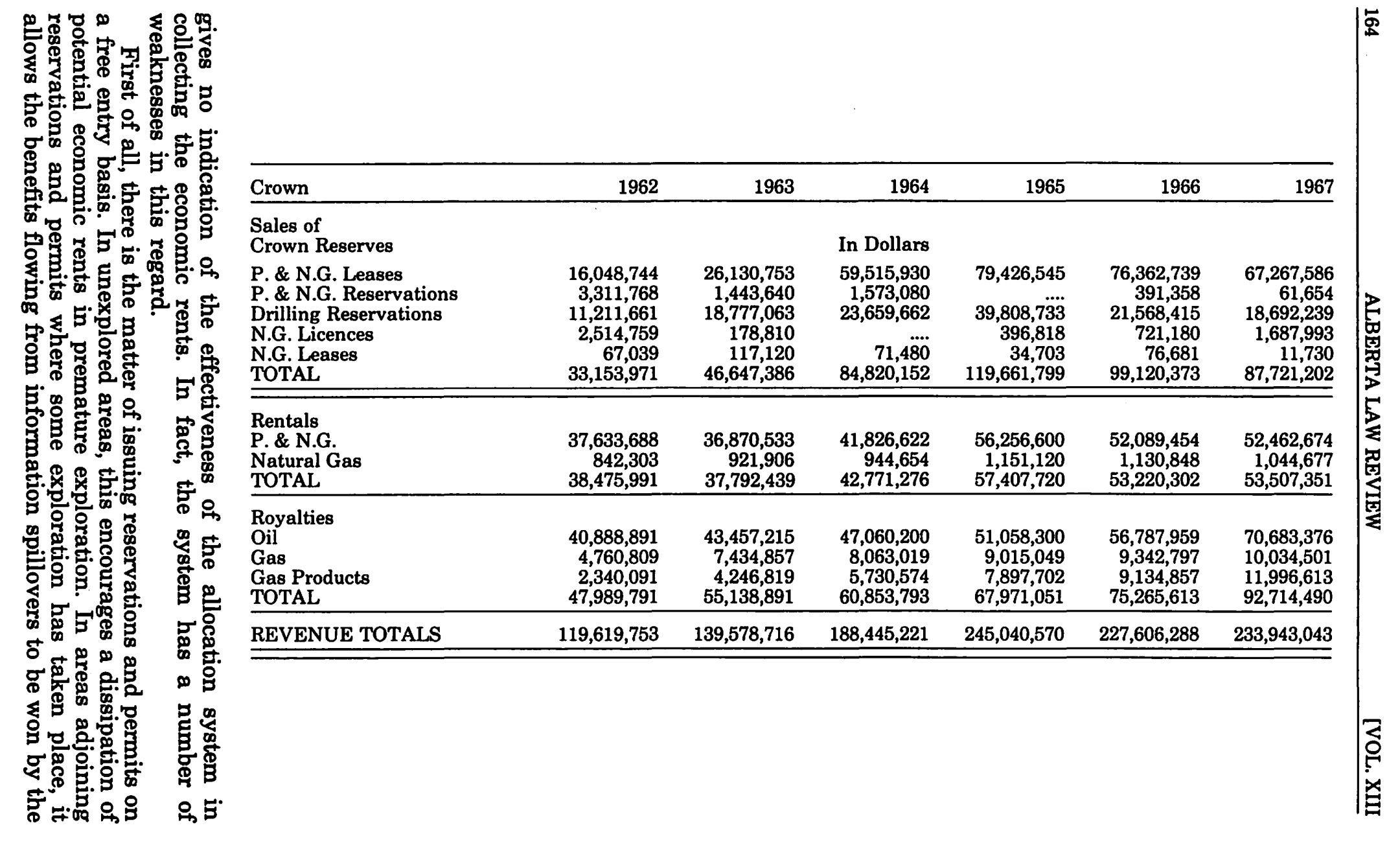




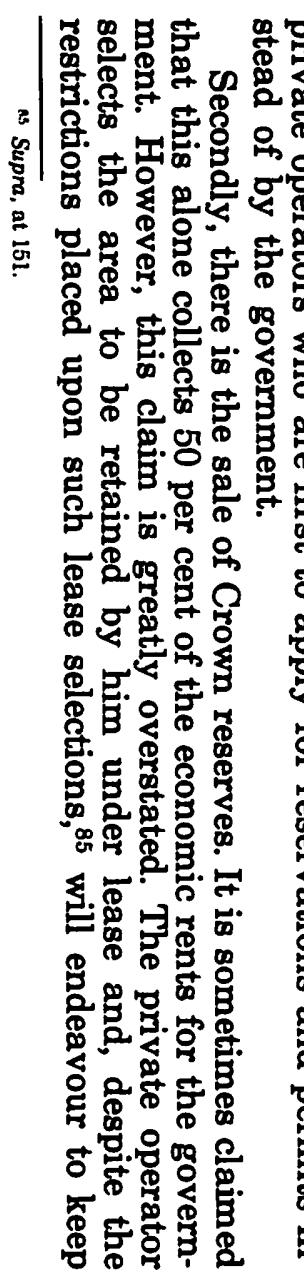

\begin{tabular}{|c|c|c|c|c|c|c|}
\hline Crown & 1968 & 1969 & 1970 & 1971 & 1972 & 1973 \\
\hline $\begin{array}{l}\text { Sales of } \\
\text { Crown Reserves }\end{array}$ & & & In Dollars & & & \\
\hline $\begin{array}{l}\text { P. \& N.G. Leases } \\
\text { P.\& N.G. Reservations } \\
\text { Drilling Reservations } \\
\text { N.G. Licences } \\
\text { N.G. Leases } \\
\text { TOTAL }\end{array}$ & $\begin{array}{r}59,752,992 \\
1,408,098 \\
30,976,528 \\
1,205,080 \\
48,500 \\
93,391,198\end{array}$ & $\begin{array}{r}42,980,012 \\
14,076,782 \\
44,565,008 \\
558,019 \\
333 \\
102,180,154 \\
\end{array}$ & $\begin{array}{r}15,462,389 \\
193,192 \\
8,069,427 \\
1,951,604 \\
11,625 \\
25,688,237 \\
\end{array}$ & $\begin{array}{r}14,253,638 \\
254,823 \\
6,714,371 \\
2,661,626 \\
37,425 \\
23,921,883 \\
\end{array}$ & $\begin{array}{r}10,368,477 \\
533,908 \\
12,688,325 \\
2,113,066 \\
23,000 \\
25,726,776 \\
\end{array}$ & $\begin{array}{r}19,274,997 \\
1,164,218 \\
18,155,516 \\
4,940,506 \\
51,000 \\
43,586,237\end{array}$ \\
\hline $\begin{array}{l}\text { Rentals } \\
\text { P. \& N.G. } \\
\text { Natural Gas } \\
\text { TOTAL } \\
\end{array}$ & $\begin{array}{r}54,071,909 \\
1,163,521 \\
55,235,430 \\
\end{array}$ & $\begin{array}{r}60,041,994 \\
1,182,505 \\
61,224,499 \\
\end{array}$ & $\begin{array}{r}54,728,634 \\
1,382,245 \\
56,110,879 \\
\end{array}$ & $\begin{array}{r}67,355,904 \\
1,488,101 \\
68,844,005 \\
\end{array}$ & $\begin{array}{r}72,884,839 \\
1,617,238 \\
74,502,077 \\
\end{array}$ & $\begin{array}{r}78,653,797 \\
1,909,393 \\
80,563,190 \\
\end{array}$ \\
\hline $\begin{array}{l}\text { Royalties } \\
\text { Oil } \\
\text { Gas } \\
\text { Gas Products } \\
\text { TOTAL }\end{array}$ & $\begin{array}{r}75,956,527 \\
11,659,377 \\
13,705,632 \\
101,321,536\end{array}$ & $\begin{array}{r}87,396,195 \\
14,003,830 \\
11,818,766 \\
113,218,791 \\
\end{array}$ & $\begin{array}{r}106,009,173 \\
17,537,169 \\
12,870,524 \\
136,416,866 \\
\end{array}$ & $\begin{array}{r}131,787,690 \\
20,989,697 \\
14,943,661 \\
167,721,048\end{array}$ & $\begin{array}{r}156,828,840 \\
22,013,207 \\
17,442,104 \\
196,284,151\end{array}$ & $\begin{array}{r}262,908,611 \\
30,321,219 \\
26,527,341 \\
319,757,171 \\
\end{array}$ \\
\hline REVENUE TOTALS & $249,948,164$ & $276,623,444$ & $218,215,982$ & $260,486,936$ & $296,513,004$ & $443,906,598$ \\
\hline
\end{tabular}


substantially more than 50 per cent of the potentially productive acreage. The Crown reserves will, therefore, usually comprise all of the inferior acreage originally within the reservation. Moreover, the effectiveness of Crown reserve sales in collecting the economic rents from this acreage depends largely upon the degree of competition in bidding, the attitude of private operators towards risk and the discount rates employed by private operators and by government. The practice whereby Crown reserves are put up for sale before the information obtained from drilling operations on nearby lands is generally available is a clear bar to competition. ${ }^{86}$ This problem would not be as serious if the government were able to make an accurate assessment of the value of Crown reserves, and to fix minimum bids accordingly, but this is not possible at present. The government is handicapped in this endeavour by lack of access to geophysical data processed by private enterprise. If private operators are averse to risk, or incur costs in spreading risk among ventures, their bids for Crown reserves will be reduced accordingly. Finally, a competitive bidding system will not derive for the government all of the economic rents if the discount rate employed by industry in calculating bids is greater than the social discount rate. Since this is likely, ${ }^{87}$ it represents a further difficulty encountered in the sale of Crown reserves.

Thirdly, a gross royalty, whether fixed or calculated according to a sliding scale which increases with either production or price, is incapable of obtaining for the Alberta government more than a share of the economic rents generated by oil and gas production. There are a number of factors which are important in determining the size of the economic rents in any field. These are the quantity of oil and gas capable of production, the costs of discovery and production, the rate of production and the selling price. None of the Alberta royalty schedules takes full account of all these factors. Moreover, the characteristics of oil and gas fields vary so considerably from one to another that it would not be possible to devise a single royalty scale capable of obtaining all of the economic rents from all fields throughout the province.

The Alberta allocation system gives the government great flexibility in fixing and revising applicable royalty rates.88 On the one hand, this flexibility is an important factor in determining the equity of the system as it allows the government to take account of unforseen changes in price and market conditions and to share in any benefits therefrom. On the other hand, though, this imports a degree of uncertainty into the allocation system for which private enterprise must compensate by higher discounting of future revenues. The price of this flexibility is paid in reduced government revenues from Crown reserve sales and the requirement of a higher private return from investment in exploration and production.

Finally, it should be recognized that any loss of efficiency resulting from the allocation system reduces the size of the economic rents

\footnotetext{
so It is sometimes said that limitations placed upon the dissemination of information prior to lease sales result in higher bids for the government, since lack of information leads to a greater dispersion in amounts bid for a single tract, and the government is free to accept the highest bid. This assumes that bidders are risk takers, and do not discount bids for uncertainty, a matter which is discussed in more detail, infra, at 203. Furthermore, any increase in high bids would be a short term phenomenon only, as bidders offering more than the economic rents for a tract would be driven out of business in the long term by their failure to recover their capital and an appropriate return thereon.

o7 A number of distortions in the market mechanism, principally those resulting from the income tax system and capital market imperfections, make this appear likely.

ss Supra, at 152.
} 
generated by oil and gas production, which represent the maximum revenues potentially available to the government of Alberta from these publicly-owned resources.

\section{EXPLORATION}

\section{Geophysical Work}

Geophysical operations may be conducted upon practically all lands in Alberta, including those subject to a reservation or lease held by another. ${ }^{89}$ In the case of private land the consent of the owner or occupier is required. The conduct of geophysical operations is regulated by a system of licences, issued by the Director of Minerals. A licence remains in force for one year, but is renewable thereafter.90 The holder of a licence is obliged to file reports on operations with both the Department of Mines and Minerals and the Energy Resources Conservation Board, but there is no requirement for disclosure of raw data from geophysical surveys.91

\section{Government Incentives}

Two special incentives are offered for exploratory drilling. ${ }^{92}$ One is a government contribution towards drilling costs, the other an exemption from Crown royalty upon oil and gas production. Both are restricted to wells certified by the Energy Resources Conservation Board"93 as "incentive exploratory wells". ${ }^{4}$

The government contribution towards drilling costs takes the form of a credit applicable against rentals, royalties and penalties due under Part 5 of The Mines and Minerals Act, the purchase price of Crown reserves, and taxes levied under The Freehold Mineral Taxation Act. ${ }^{95}$ Drilling of the well must have commenced before December 31, 1977, and a credit established thereby must be applied against moneys or taxes payable prior to December 31,1979 . The amount of the credit allowed depends upon a determination by the Board, after the well is completed and all relevant drilling information is supplied to the Board. Intervals of depth may qualify either as class A footage or as class B footage. This determination is based upon the proximity of the nearest abandoned or completed well. The amount of credit also varies according to the locality of the well in the province, being lowest in the plains area where drilling costs are cheapest, higher in the northern area, and highest in the foothills area where drilling costs are greatest. Details of the credit available for class A and class B footage, respectively, are reproduced in Tables 4 and 5 . The intent of the subsidy programme is to contribute about 40 per cent of the cost of drilling class $\mathrm{A}$ footage and about 30 per cent of the cost of drilling class $B$ footage. ${ }^{96}$

89 All operations are subject to the Geophysical Regulations, Alta. Reg. 26/59 (1959) as amended by Alta. Regs. $425 / 59$ (1959), 271/65 (1965), 38/69 (1969) and 238/70 (1970). For exceptions to the lands upon which operations may be conducted, see section 5. Operations include

(a) seismic operations, (b) gravimetric operations, (c) magnetic operations, (d) electrical operations, (e) geochemical operations, (f) test drilling, and $(g)$ other methods of investigating subsurface.

- The Mines and Minerals Act, supra, n. 13 at 8. 189.

91 Id. at 8.193.

92 Exploratory Drilling Incentive Regulations, Alta. Reg. 18/74 (1974).

93 For a discussion of the history, composition and activities of the Board, see infra at 171.

94 Exploratory Drilling Incentive Regulations, 1974, supra, n. 92 at s. 2

ss Id. at s. 10. The Freehold Mineral Taxation Act, S.A. 1973, c.89, imposes a tax upon oil and gas reserves sub. ject to private ownership in the ground.

Oilweek, February 4, 1974 at 9. 
TABLE 4

\section{DRILLING INCENTIVE CREDIT}

Applicable to Class A Footage

Class A footage shall be determined as being the depth interval of a well that has not been duplicated either by

(i) a drilled and abandoned well within approximately one and one-half miles, or

(ii) a completed well or a well that in the opinion of the Board warrants completion, within approximately three miles.

\begin{tabular}{|c|c|c|c|c|c|c|}
\hline \multicolumn{7}{|c|}{ Basis for Credit } \\
\hline & \multicolumn{2}{|c|}{ Plains Area } & \multicolumn{2}{|c|}{ Northern Area } & \multicolumn{2}{|c|}{ Foothills Area } \\
\hline $\begin{array}{r}\text { Depth, } \\
\text { Feet }\end{array}$ & $\begin{array}{r}\text { Cumula- } \\
\text { tive } \\
\text { Dollars }\end{array}$ & $\begin{array}{l}\text { Incre- } \\
\text { mental } \\
\$ / \text { foot }\end{array}$ & $\begin{array}{r}\text { Cumula- } \\
\text { tive } \\
\text { Dollars }\end{array}$ & $\begin{array}{l}\text { Incre- } \\
\text { mental } \\
\$ / \text { foot }\end{array}$ & $\begin{array}{r}\text { Cumula- } \\
\text { tive } \\
\text { Dollars }\end{array}$ & $\begin{array}{l}\text { Incre- } \\
\text { mental } \\
\$ / \text { foot }\end{array}$ \\
\hline 0 & 0 & & 0 & & 0 & \\
\hline 1,000 & 4,000 & 4.00 & 6,000 & 6.00 & 8,000 & 8.00 \\
\hline 2,000 & 8,000 & 4.00 & 12,000 & 6.00 & 17,000 & 9.00 \\
\hline 3,000 & 13,000 & 5.00 & 19,000 & 7.00 & 27,000 & 10.00 \\
\hline 4,000 & 19,000 & 6.00 & 27,000 & 8.00 & 38,000 & 11.00 \\
\hline 5,000 & 26,000 & 7.00 & 36,000 & 9.00 & 50,000 & 12.00 \\
\hline 6,000 & 34,000 & 8.00 & 47,000 & 11.00 & 64,000 & 14.00 \\
\hline 7,000 & 44,000 & 10.00 & 60,000 & 13.00 & 81,000 & 17.00 \\
\hline 8,000 & 59,000 & 15.00 & 79,000 & 19.00 & 104,000 & 23.00 \\
\hline 9,000 & 79,000 & 20.00 & 102,000 & 25.00 & 132,000 & 28.00 \\
\hline 10,000 & 105,000 & 35.00 & 132,000 & 40.00 & 168,000 & 48.00 \\
\hline 11,000 & 140,000 & 47.00 & 172,000 & 50.00 & 216,000 & 56.00 \\
\hline 12,000 & 187,000 & 62.00 & 222,000 & 66.00 & 272,000 & 72.00 \\
\hline 13,000 & 249,000 & 83.00 & 288,000 & 85.00 & 344,000 & 96.00 \\
\hline 14,000 & 332,000 & 110.00 & 373,000 & 107.00 & 440,000 & 120.00 \\
\hline 15,000 & 442,000 & 147.00 & 480,000 & 148.00 & 560,000 & 160.00 \\
\hline 16,000 & 589,000 & 196.00 & 628,000 & 184.00 & 720,000 & 200.00 \\
\hline 17,000 & 785,000 & 255.00 & 812,000 & 228.00 & 920,000 & 240.00 \\
\hline 18,000 & $1,040,000$ & 340.00 & $1,040,000$ & 316.00 & $1,160,000$ & 320.00 \\
\hline
\end{tabular}

SOURCE: Exploratory Drilling Incentive Regulations, Alta. Reg. 18/74 (1974), Schedule A. 
TABLE 5

\section{DRILLING INCENTIVE CREDIT}

Applicable to Class B Footage

Class $B$ footage shall be determined as being the depth interval of a well that has been duplicated by the deepest drilled and abandoned well within approximately one and onehalf miles, providing that such depth interval has not been duplicated within approximately three miles by a completed well or a well that in the opinion of the Board warrants completion.

\begin{tabular}{|c|c|c|c|c|c|c|}
\hline \multicolumn{7}{|c|}{ Basis for Credit, } \\
\hline & \multicolumn{2}{|c|}{ Plains Area } & \multicolumn{2}{|c|}{ Northern Area } & \multicolumn{2}{|c|}{ Foothills Area } \\
\hline $\begin{array}{r}\text { Depth, } \\
\text { Feet }\end{array}$ & $\begin{array}{r}\begin{array}{r}\text { Cumula- } \\
\text { tive } \\
\text { Dollars }\end{array} \\
\end{array}$ & $\begin{array}{l}\text { Incre- } \\
\text { mental } \\
\$ / \text { foot }\end{array}$ & $\begin{array}{r}\text { Cumula- } \\
\text { tive } \\
\text { Dollars }\end{array}$ & $\begin{array}{l}\text { Incre- } \\
\text { nental } \\
\$ / \text { foot }\end{array}$ & $\begin{array}{r}\text { Cumula- } \\
\text { tive } \\
\text { Dollars }\end{array}$ & $\begin{array}{l}\text { Incre- } \\
\text { mental } \\
\$ / \text { foot }\end{array}$ \\
\hline 0 & 0 & & 0 & & 0 & \\
\hline 1,000 & 3,000 & 3.00 & 4,000 & 4.00 & 6,000 & 6.00 \\
\hline 2,000 & 6,000 & 3.00 & 9,000 & 5.00 & 13,000 & 7.00 \\
\hline 3,000 & 10,000 & 4.00 & 14,000 & 5.00 & 21,000 & 8.00 \\
\hline 4,000 & 14,000 & 5.00 & 20,000 & 7.00 & 29,000 & 9.00 \\
\hline 5,000 & 19,000 & 6.00 & 27,000 & 8.00 & 38,000 & 11.00 \\
\hline 6,000 & 25,000 & 8.00 & 35,000 & 10.00 & 49,000 & 13.00 \\
\hline 7,000 & 33,000 & 11.00 & 45,000 & 14.00 & 62,000 & 16.00 \\
\hline 8,000 & 44,000 & 15.00 & 59,000 & 18.00 & 78,000 & 21.00 \\
\hline 9,000 & 59,000 & 20.00 & 77,000 & 22.00 & 99,000 & 27.00 \\
\hline 10,000 & 79,000 & 26.00 & 99,000 & 30.00 & 126,000 & 36.00 \\
\hline 11,000 & 105,000 & 35.00 & 129,000 & 38.00 & 162,000 & 42.00 \\
\hline 12,000 & 140,000 & 47.00 & 167,000 & 49.00 & 204,000 & 54.00 \\
\hline 13,000 & 187,000 & 62.00 & 216,000 & 64.00 & 258,000 & 72.00 \\
\hline 14,000 & 249,000 & 83.00 & 280,000 & 80.00 & 330,000 & 90.00 \\
\hline 15,000 & 332,000 & 110.00 & 360,000 & 111.00 & 420,000 & 120.00 \\
\hline 16,000 & 442,000 & 147.00 & 471,000 & 138.00 & 540,000 & 150.00 \\
\hline 17,000 & 589,000 & 191.00 & 609,000 & 171.00 & 690,000 & 180.00 \\
\hline 18,000 & 780,000 & 255.00 & 780,000 & 237.00 & 870,000 & 240.00 \\
\hline
\end{tabular}

SOURCE: Exploratory Drilling Incentive Regulations, Alta. Reg. 18/74 (1974), Schedule B. 
The exemption from Crown royalty is for a period of five years in the case of oil and two years in the case of gas, calculated from the date upon which production of the well commences. It is available only in respect of production from intervals designated as class A or class B footage in wells that commenced drilling before December 31, 1977, where no other well within three miles and producing from the same pool has the benefit of the exemption.97

Incentives of this type for exploratory drilling were first introduced in December 1972 when the Alberta government increased the maximum oil royalty rate from $162 / 3$ per cent to 25 per cent..$^{98}$ They were designed to offset the effect of this increase upon exploration in the province, and then, as now, were intended to be particularly attractive to small operators who, in the government's opinion, are responsible for the vast majority of drilling activity in Alberta in recent years.99

The drilling subsidy affects both the level and timing of investment in exploration. From the point of view of the private operator, it reduces the marginal cost of exploratory drilling so that some areas previously outside the extensive margin are brought within it. Moreover, as the scheme is of limited duration it encourages the drilling of intra-marginal wells while it remains in force instead of at some future time.

The royalty exemption also influences both the level and timing of investment in exploration, the former by increasing the expected value to the private operator of marginal revenue from production and the latter by operating for a specified time only. The exemption may also affect the timing of production from a well by encouraging the operator to tilt production rates as far as possible towards the present at the expense of the future, subject to maximum allowable production rates. However, this is unlikely to be significant as the effect of discounting will probably also cause this result even in the absence of the royalty exemption. 100

Incentives for exploration in Alberta are required because of two features of the government allocation system for Crown oil and gas rights, these being information spillovers and the imposition of gross royalties at substantial rates. Information spillovers are caused when a private operator is unable to obtain the full benefits generated by his exploration programme. This happens when his reservation or permit is not large enough to encompass the total area about which he derives information during exploration, and particularly as a result of the obligation to surrender to the Crown at least 50 per cent of his reservation acreage. ${ }^{101}$ The inability to benefit fully from exploration causes less investment in exploration than is warranted by the social benefits therefrom, and so government subsidy of exploration is called for. The imposition of gross royalties has the same effect as discussed earlier in relation to investment in production facilities.102 By driving a wedge between social and private marginal revenues and costs, such royalties reduce the level of investment in exploration below that which is best for society. Again, government subsidy of exploration is required.

\footnotetext{
${ }^{97}$ Exploratory Drilling Incentive Regulations, 1974, supra, n. 92 at ss. 11-12.

98 Exploratory Drilling Incentive Regulations, Alta. Reg. 387/72 (1972), now superseded.

99 Oilweek, February 4, 1974 at 8.

100 This tilting effect is discussed in Scott, The Theory of the Mine under Conditions of Certainty, published in Gaffney (ed.), Extractive Resources and Taxation (1967).

101 Supra, at 151.

102 Supra, at 161.
} 
The degree to which the Alberta exploration incentives provide solutions to this problem is difficult to assess. The drilling credit is similar to a Crown subsidy for specified exploratory operations. Nevertheless, it provides a partial solution only as no subsidy is given for pre-drilling exploratory expenditures such as costs incurred in geological and geophysical operations. The royalty exemption increases the return to private operators from exploration and production ${ }^{103}$ and thereby offsets the disincentive effects of information spillovers and gross royalties, but its effectiveness must depend upon the magnitude of these different effects.

Finally, it should be noted that the incentives do not contain any provisions of special benefit to small, independent operators, despite the government's wish to assist them. It would seem that the problem faced by such operators are spreading of risk ${ }^{104}$ and obtaining access to capital. Risk may be spread by entry into a number of joint ventures, though these involve transactions costs. The subsidy for drilling costs reduces risk but does not assist in spreading the residue among a number of ventures. The royalty exemption may operate as a source of risk capital if the operator succeeds in achieving production but does not make entry any easier for the new explorer. In summary, while these incentives are undoubtedly useful to many small independents and may in fact be used more by them than by the majors, they are not directed specifically toward the disadvantages faced by these independents and are equally available to all, large and small.

\section{PRODUCTION}

Government regulation of the many aspects of oil and gas production in Alberta has long been entrusted to the Energy Resources Conservation Board, which was established originally in 1938 under the name of the Petroleum and Natural Gas Conservation Board. In 1971, when the Board received its present name, its jurisdiction was extended to the coal, the hydro and the electric energy industries. It consists of five members appointed by the Lieutenant Governor in Council, assisted by a staff of 436, including advisory and technical people. ${ }^{105}$ Each year the Board levies a tax upon the assessed value of all oil and gas properties in the province at a rate calculated to produce half of its estimated expenditures during the fiscal year. ${ }^{106}$ Remaining expenditures are met from provincial government revenue. ${ }^{107}$

Before considering the types of controls placed by the Board upon oil and gas production practices in Alberta it is useful to review some of the physical and economic factors relevant to the accumulation and production of these substances. ${ }^{108}$ Reservoirs, or pools, of oil and gas occur in the ground when certain geologic conditions are met. The fluids are contained in porous rock from which they are prevented from escaping by a

\footnotetext{
103 Supra, at 170.

104 Spreading of risk is not a problem, of course, if small independents are not risk averse. However, the tendency for such operators to enter into joint ventures, despite the transactions costs involved, suggests that there is a degree of risk aversion among small independento. For a more detailed discussion of the problem of risk, see infra, at 203 et seq.

105 Conservation in Alberta, 1973, Calgary, ERCB, February 1974. The statute presently establishing the Board is The Energy Resources Conservation Act, S.A. 1971, c.30, as amended by S.A. 1972, c.54.

106 The Oil and Gas Conservation Act, R.S.A. 1970, c.267, as amended by S.A. 1971, cs.30 and 119, S.A. 1972, c.74, and S.A. 1974, c.48; at s. 67 .

107 The Energy Resources Conservation Act, supra, n. 105 at 8. 18.

108 This account relies heavily upon Bradley, The Economics of Crude Petroleum Production (1967) at 42-45.
} 
surrounding impenetrable formation. The most common type of reservoir is the anticlinal (or structural) trap, which results from an upfolding in rock strata creating a dome-like structure. The oil and gas are held in place by an impervious layer of rock above, and, frequently, a layer of water below. A second reservoir type is the fault-sealed trap, which occurs when a porous rock stratum is abruptly broken by a fault creating a barrier of impenetrable rock. If the porous stratum is tilted, oil and gas will migrate upwards until they accumulate at the fault. A third reservoir type is the stratigraphic trap, caused by a change in the permeability ${ }^{109}$ of a geologic stratum instead of by a fault. The porosity and total volume of the rock comprising a reservoir determine the amount of oil and gas that may be contained therein. The permeability of the rock controls the production rates which may be obtained. Well production rates are also determined by the energy available to overcome resistance to flow.

Three types of reservoir energy, or drive, may be present either alone or in combination. They are gas cap drive, solution gas drive and water drive. A gas cap exerts pressure on the oil from above so that when a well is drilled into the oil zone, the oil flows to the surface. Gas held in solution exerts pressure on the oil internally, with the same result. Water drive exerts pressure on the oil and gas above by encroachment through the porous rock as production takes place. These types of reservoir energy are described as primary recovery mechanisms.

Production of oil or gas from a reservoir is necessarily accompanied by a decline in reservoir pressure, which in turn reduces the productive capacity of wells therein. The rate of decline depends upon individual reservoir characteristics and especially upon the nature of the drive mechanism. At times it may be possible to maintain or even increase reservoir pressure by introduction of water, gas or other suitable fluids into the producing formation. This procedure is variously described as artificial, secondary or enhanced recovery.

The productivity of a reservoir is less than proportional to the number of wells drilled therein because past a certain point there is well interference, caused by the fact that total reservoir energy is limited. In fact, the area over which oil and gas migrate through porous rock may be very wide, so that one well might ultimately drain a very large reservoir.110 If it were not for the time preference of private operators and society, this would provide the cheapest method of developing a reservoir. Taking that time preference into account, though, means that a single operator developing a reservoir will find it worthwhile to invest in further production facilities up to the point where, in present value terms, the marginal benefit from earlier production equals the marginal cost of additional investment.

However, development of a reservoir is not a single stage process whereby all necessary wells are drilled before production commences. Wells need to be periodically worked over either for cleaning or to improve the rate of flow by fracturing the zone around the well bore. As reservoir pressure declines, consideration must also be given to the adoption of enhanced recovery schemes or the drilling of further production

109 Permeability is a measure of the ease with which fluids flow through porous rock.

110 Muskat, Physical Principles of Oil Production (1949) at 591, 858-62 and 899, and Craze, Development Plan for Oil Reservoirs in Frick and Taylor (edo.), Petroleum Production Handbook (1962) at 33.5-33.20, quoted in Adelman, The World Petroleum Market (1972) at 19. 
wells. Investment in production facilities is a continuing process throughout the life of a reservoir.111

It follows that the natural unit for the development of oil and gas deposits is the reservoir. Nevertheless, although this was recognized as early as 1940 in Alberta, ${ }^{112}$ other considerations have been more important in the regulation of production. The division of freehold land rights is effected on a neat rectangular basis in Alberta, and so is the allocation of Crown oil and gas rights, so that there is no correspondence with sub-surface geological formations. To this factor the courts have added the rule of capture.

This rule is an adjunct to the legal ownership theory applicable to oil and gas in the ground. In the major producing states of the United States, where public ownership of oil and gas is virtually unknown, there were considerable differences of opinion as to the nature of this ownership, ${ }^{113}$ and in Canada this issue has not yet been conclusively determined.114 Nevertheless, whichever ownership theory was adopted in each jurisdiction, the rule of capture was recognized.115 This rule states simply that, irrespective of the nature of title to oil and gas below the surface, a person producing these substances from a well located upon lands for which he holds the mineral rights acquires title to the oil and gas upon their reduction to possession. Thus, owners of mineral rights for adjoining lands covering a single oil and gas reservoir are placed in competition with one another to produce from the pool before the opportunity to do so is lost.115a

III Id. at 20.

112 The 1940 Royal Commission on Alberta's Oil Industry reported this fact; see Harrison, Regulation of Oil Well Spacing, (1970) 8 Alta. L. Rev. 357 at 367.

11 Three main theories of ownership have been espoused in the United States: the non-ownership (or Oklahoma) theory, the qualified ownership (Pennsylvania) theory and the ownership in place (Texas) theory. Under the non-ownership theory, no person owns oil and gas until it is produced and any person may "capture" the oil and gas if able to do so. However, a person may not go upon the land of another to effect the capture, so it is necessary to have an interest in land authorizing the drilling of the well used to effect the capture. The qualified ownership theory does recognize property rights in oil and gas in the ground but regards them as something less than a fee. Owners of these rights can not be absolutely deprived of them without this amounting to a taking of private property. But where several owners have similar rights in respect of a common source of supply of oil and gas, the rights of one may effectively be lost through a failure to exercise them prior to depletion of the source. The ownership in place theory, now the most widely accepted of the three, regards an interest in oil and gas in the ground as the same as an interest in solid minerals, that is to say, as forming part of the fee. It is sometimes called the absolute ownership theory. However, the interest may be lost be depletion of a common pool by an adjoining landowner, the courts rationalized this situation by describing the fee as "defeasible". There is widespread difference of opinion among writers as to the clasaification of these theories and their application in different states. See Williems and Meyers, Oil and Gas Law (1972) Vol. 1, Cap 2 at 203; Summers, Th. Law of Oil and Gas, (1954) Vol. 1, Cap. 2 at 11; Laycraft and Head, Theories of Ownership of Oil and Gas (1953) 31 Can. Bar Rev. 382.

114 The Privy Council was given the opportunity to choose among the different ownership theories in Borys v. Canadian Pacific Railway and Imperial Oil Limited [1953] A.C. 217 but declined to do 80 . Their Lordships said at 229 :

For the purpose of their decision their Lordships are prepared to assume that the gas whilst in situ is the property of the appellant even though it has not been reduced into passession, but the question is not whose property the gas is, but what means the respondents have use to recover their petroleum.

See MacIntyre, The Development of Oil and Gas Ownership Theory in Canada, (1969) 4 U.B.C.L. Rev. 245, who points out that there are persuasive arguments favouring adoption of the ownership in place theory in Canada.

11 The rule of capture is apparent in each of the ownership theories applied in the United Sates, supra, n. 113. Acceptance of the rule in Canada has never seriously been questioned; MacIntyre, id. at 265; and the rule was confirmed by the Privy Council in Borys v. Canadian Pacific Railway and Imperial Limited, id. at 220. Their Lordships said:

If any of three substances [gas, oil and water] is withdrawn from a portion of the property which does not belong to the appellant but lies within the same contained and any oil and gas situated in his property thereby filters from it to the surrounding lands, admittedly he has no remedy. So, also, if any substance is withdrawn from his property, thereby causing any fugacious matter to enter his land, the surrounding owners have no remedy against him. The only safeguard is to be the first to get to work, in which case those who made the recovery become owners of the material which they withdrew from any well which is situated on their property or from which they have authority to draw.

115aThe results of this competition in the early oil-producing days in the United States are described by Ise, The United States Oil Policy (1926) at 105 et seq. 
In these circumstances, an operator must ignore the future in deciding upon current production plans. User cost is zero since any oil and gas not produced today may not be available for production in the future. Production continues up to the point where price equals the marginal cost of present production. This rate is faster than that chosen where the reservoir is subject to sole ownership and price is equated to the sum of marginal and user costs, both of which are then positive.

Government regulation of production in Alberta has been directed towards achieving a reduction in the rates of production which normally prevail when the rule of capture is in force in a pool. Such rates may cause not only a substantial loss in economic efficiency through the misallocation of production over time, but also a reduction in the total quantity of oil and gas recovered from a pool by rapid dissipation of reservoir energy. A number of regulatory devices have been adopted.

\section{Well Spacing ${ }^{116}$}

The Board controls the drilling of all wells in the province by a system of well licences. ${ }^{117}$ The minimum area in respect of which a well licence may be obtained is a drilling spacing unit. A person having oil and gas rights in part only of a drilling spacing unit is required, before drilling a well, to obtain the authorization of those holding the rights in the remaining area of the spacing unit. The process of combining rights in a drilling spacing unit for the purpose of drilling a well is known as pooling. In the event that it is not possible for an owner of oil and gas rights to obtain a voluntary pooling agreement, the Board may, with the approval of the Lieutenant Governor in Council, order compulsory pooling after a hearing into the matter. ${ }^{118}$

The drilling spacing unit for oil is usually 160 acres while that for gas is 640 acres. ${ }^{119}$ In special cases the Board may prescribe different areas. ${ }^{120}$ Where a pool is subject to a unit agreement the Board may, on application, order a variation or suspension of the spacing requirements regarding that pool. ${ }^{21}$

The size of the drilling spacing unit for oil has increased over the years, from 40 acres in 1950 to 80 acres in 1957 and then to 160 acres in 1962. However, a few oil reservoirs have been developed on more than one spacing pattern.122 Drilling spacing units for gas have been set at 640 acres since $1952 .{ }^{123}$ The Board requires that any variation in the normal spacing pattern be shown to have economic advantages. There is little tendency today for spacing units to increase in size; on the contrary, the Board is now receiving a number of applications for permission to conduct infill drilling. ${ }^{124}$ In considering these applications the Board is concerned to protect the rights of other operators in the pool and will not

\footnotetext{
116 For an account of the history of well spacing in Alberta, see Harrison, supra, n. 112

117 The Oil and Gas Conservation Act, supra, n. 106 at 88. 23-32.

118 Id. at 8.82.

110 Oil and Gas Conservation Regulations, Alta. Reg. 151/71 (1971 as amended by Alta. Regs. 241/71 (1971), $69 / 72$ (1972), 140/72 (1972), 233/73 (1973), and $144 / 74$ (1974); at s. 4.020 .

$120 \mathrm{Id}$. at 8. 4.030 .

121 The Oil and Gas Conservation Act. supra, n. 106 at s. 81(4).

122 Watkins, G.C., Proration and the Economics of Oil Reservoir Development, Province of Alberta, Canada, Un. iversity of Leeds, unpublished Ph.D. thesis, 1971 at $120-1$.

123 Harrison, supra, n. 112 at 371.

124 Infill drilling is further drilling within the area of a spacing unit already containing a well.
} 
usually give the necessary permission unless there is substantial agreement among operators that infill drilling is required. ${ }^{125}$

The Board also designates the precise location of a well within a drilling spacing unit. ${ }^{126} \mathrm{~A}$ well drilled outside the target area suffers a penalty in the form of a reduction in its allowed maximum rate of production. ${ }^{127}$

The regulation of well spacing places a limit upon the tendency induced by the rule of capture toward excessive and competitive investment in production wells. This limit, however, is an arbitrary one in that it is basically insensitive to the physical and economic characteristics of individual pools which, in the absence of the rule of capture, would determine the appropriate drilling and production plan. Any uniform system of well spacing must have this result. It may assist in mitigating the inefficiency caused by the rule of capture but is incapable of removing it entirely.

\section{Production Rate Limitation}

An operator who obtains a licence from the Board for the drilling of a well is required to supply all relevant well data to the Board.128 If the well is capable of production, the operator must also supply reports on tests conducted as well as subsequent production history. ${ }^{129}$ One year after the well is completed, the Board is obliged to make such information available to the public. ${ }^{130}$

The Board uses the information collected with regard to all wells in the province to monitor and evaluate production practices. The Oil and Gas Conservation Act"131 forbids the commission of "waste", which is defined, in addition to its "ordinary meaning", to include "wasteful operations", which are in turn defined as follows: 132

(i) the locating, spacing, drilling, equipping, completing, operating or producing of a well in a manner that results or tends to result in reducing the quantity of oil, gas or crude bitumen ultimately recoverable from a pool or oil sands deposit under sound engineering and economic principles, or

(ii) the locating, drilling, equipping, completing, operating or producing of a well in a manner that causes or tends to cause excessive surface loss or destruction of oil, gas or crude bitumen, or,

(iii) the inefficient, excessive or improper use or dissipation of reservoir energy however caused, or

(iv) the failure to use suitable enhanced recovery operations in a pool where it appears probable on the basis of available information that such methods would result in increasing the quantity of oil or gas ultimately recoverable from the pool under sound engineering and economic principles or,

(v) the escape or the flaring of gas, if it is estimated that, in the public interest and under sound engineering principles and in the light of economics and the risk factor involved, the gas could be gathered, processed if necessary, and it or the products therefrom marketed, stored for future marketing, or beneficially injected into an underground reservoir, or

(vi) the inefficient storing of oil, gas or crude bitumen, whether on the surface or underground, or

125 Communication with the Technical Assistant to the Chairman of the Baord, Calgary, 25 July, 1974. In addition, see the Boand's Informational Letter No. IL-OG 72-11, Well Spacing and Infill Wells in Oil Pools.

128 Oil and Gas Conservation Regulations, supra, n. 119 at s. 4.020.

127 Id. at 8. 4.070 .

120 Oil and Gas Conservation Regulations, supra, n. 119 at Part II.

129 Id. at Part 12.

130 Id. at 8. 12.150 .

131 Supra, n. 106.

132 Id. at 8. 138.2 . 
(vii) the production of oil, gas or crude bitumen in excess of proper storage facilities or of transportation and marketing facilities or of market demand therefor.

In recognition of the fact that, beyond a critical rate of production, the total volume of oil which may be recovered from a reservoir is inversely related to the production rate, the Board places limits upon production rates for reservoirs, portions thereof and individual wells therein. The degree of sensitivity of oil recovery to production rate varies according to the physical characteristics of the reservoir, the stage of reservoir depletion, and particularly the drive mechanism. Recovery of oil by means of solution gas drive is largely independent of production rate within practical limits, recovery by gas cap drive is more sensitive to production rate than the solution gas mechanism, and recovery by means of water drive is most sensitive to the rate of production. In the case of a combination of several active drives, production rate may affect total recovery through both its influence upon the effectiveness of each drive and the part played by each drive in the combined recovery mechanism. Although individual well production rates do not necessarily affect total reservoir recovery, in some circumstances the well rate can cause segmentation of a reservoir by water or gas coning or local encroachment of active water and thus reduce ultimate recovery. ${ }^{133}$

The Board has provided the following assessment of the relationship between the maximum efficient rate (MER) of a pool, defined as the maximum rate at which oil can be produced without avoidable underground waste, 134 and well spacing. It is depicted in Figure 3. For a reservoir of given physical characteristics and producing under a given recovery mechanism, there is a reservoir MER independent of individual well effects, which is constant at any particular stage of depletion regardless of spacing. This is indicated by the line $A B C$ on the figure. Similarly, for each well there is in principle an individual well MER, which varies almost inversely with spacing. This is indicated by the line DBE. The well spacing corresponding with the point of intersection B depends upon the reservoir rock characteristics, the mobility of the reservoir fluids and the recovery mechanism. Where the actual spacing is closer than that corresponding with B, the MER for the pool is the reservoir MER represented by the line $A B$. Where the actual spacing is wider than that corresponding with $\mathrm{B}$, the MER for the pool is determined by the summation of the individual well, MERs, represented by the line BE. Thus, in general, the relationship between pool MER and spacing takes the form of the line ABE. In addition, however, the Board considers that there may be special cases where loss of pool recovery could result from excessive rates of production at individual wells, even where withdrawals from the pool as a whole are not in excess of the MER.

There is no universally applicable formula for the determination of MERs. The calculation of actual reservoir MERs requires representative reservoir fluid and rock data, significant performance history and detailed knowledge of recovery processes, and, therefore, time to evaluate each new discovery. ${ }^{135}$ In the absence of such a formula, therefore, the

\footnotetext{
133 Watkins, supra, n. 122 at 18-19; Report and Decision on Review of Plan for Maximum Oil production Rate Limitation in Alberta, OGCB Report 65-3, Calgary, March 1965 at 13-17.

136 Report, id. at 18-20.

135 Id. at 25.
} 
FIGURE 3

RELATIONSHIP BETWEEN MER AND WELL SPACING

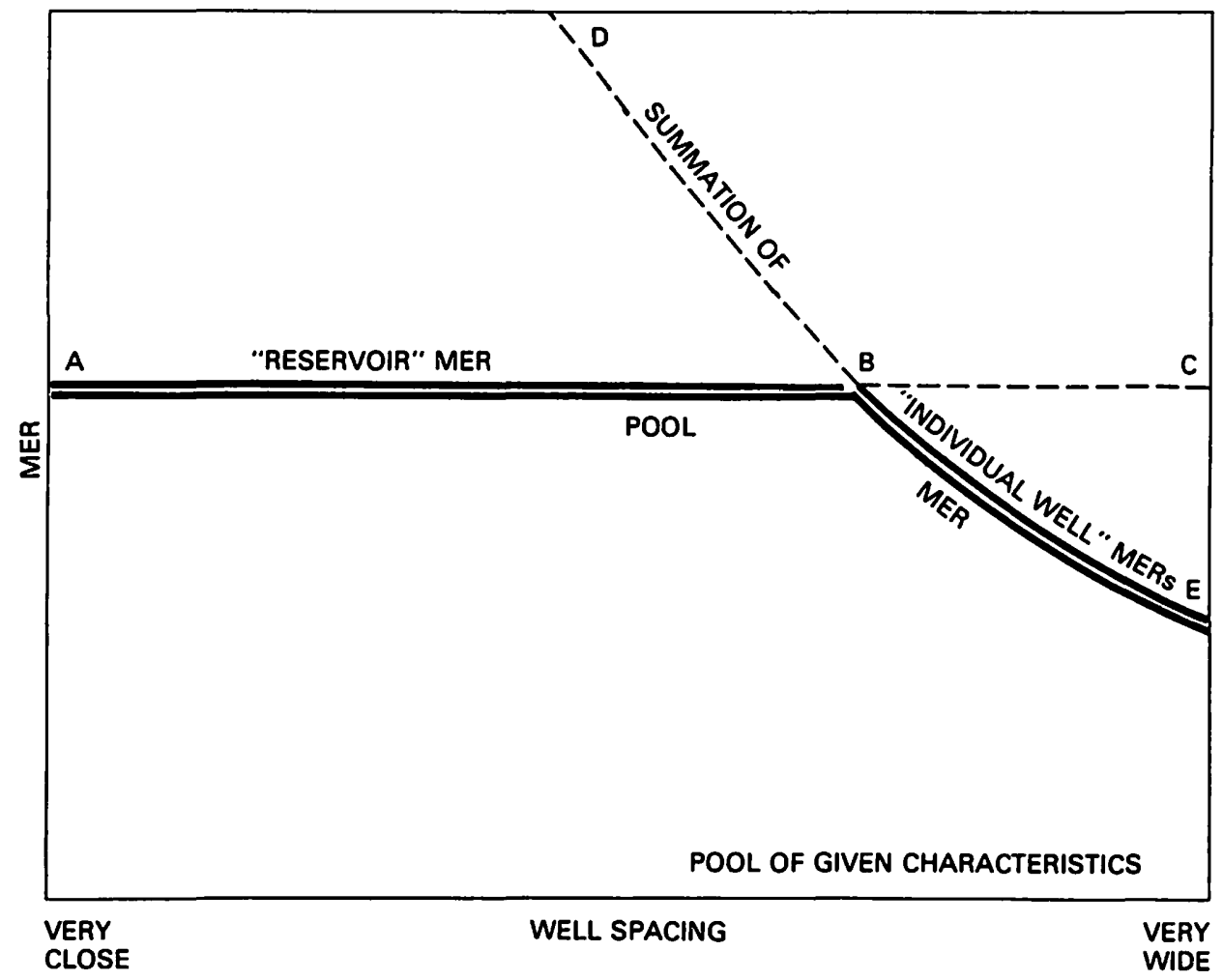

SOURCE: Report, supra, n. 133 at 20.

Board in 1965 adopted the following procedure. A few pools, most of which produce heavy crude oil, were allowed to operate under "good production practice". Generally speaking, this rule was applied only to pools of relatively low productivity discovered prior to Leduc in 1947. Such a pool was not assigned a rate limitation by the Board but the operator was required to produce his wells in such a manner as would prevent underground waste. ${ }^{136}$ Some other pools, principally those for which an enhanced recovery scheme was approved by the Board, were assigned specific MERs after a hearing in which the production characteristics and history of the pool were reviewed in detail. In the case of most pools, the Board staff determined a provisional rate limitation (PRL) by application of a general formula, and when it appeared that production from a pool would soon approach the PRL the Board requested the operators to make an MER study and submit it to the Board for consideration, usually at a public hearing..$^{137}$ In addition, the Board placed restrictions on the amount of gas or water that could be produced with any given quantity of oil, in order to maintain reservoir pressure. ${ }^{138}$ Finally, in those pools where it seemed possible that individual well

\footnotetext{
136 Id. at 40 .

137 Id. at 61 .

138 Id. The restrictions were by way of specified gas-oil ratios (GORs) and water-oil ratios (WORs).
} 
production rates could affect ultimate recovery, the Board kept well performance under surveillance and assigned maximum permissible rates (MPRs) where required. ${ }^{139}$

During 1973, the Board conducted a review of all of the oil pools in the province, some 1,500 in total. It found that the majority of the approximately 800 light and medium gravity oil pools subject to market demand prorationing ${ }^{140}$ were producing at or near capacity and that maximum rate limitations (MRLs)141 ${ }^{14}$ were required. As a result, some 145 pools or parts of pools were made subject to good production practice and some 630 pools or parts thereof were assigned MRLs, based upon reservoir and production characteristics. ${ }^{142}$

Limitations upon production rates are assigned by the Board with physical rather than economic considerations in mind.143 The objective is to allow production of the largest possible volume of oil rather than to obtain the maximum present value of the oil produced. The Board takes no account of the time preference of operators, or of society, and does not consider future price trends, in fixing limits upon rates of production. To this extent the system is inefficient. However, private operators can not be relied upon to produce at a rate which is best for society because of the likelihood of a divergence between private and social discount rates. If the private discount rate is higher than that of society, restrictions are required upon rates of production but these should be chosen to maximize the net social value of oil rather than ultimate recovery.

No general system of maximum rate limitation applies to gas reservoirs. The Board monitors production practices to ensure that ultimate recovery is not affected, and operators are subject to the blanket prohibition against waste in The Oil and Gas Conservation Act.

The Board also uses well and reservoir production information to supervise enhanced recovery schemes. All such schemes require Board approval before going into operation..$^{144}$ At the end of 1973, there were 370 schemes in force in some 230 pools in Alberta, and the Board calculated that about one-third of the province's original recoverable reserves were attributable to them..$^{145}$

Moreover, the Board may require enhanced recovery in any pool or portion thereof, with the approval of the Lieutenant Governor in Council, when necessary to prevent waste. ${ }^{146}$ The most common example of the Board's exercise of this power is when an application for installation of a scheme is received from one operator in a pool, and the Board, after a public hearing, decides that the scheme should be extended throughout the entire pool. However, there are occasions upon which the Board has initiated a scheme by calling upon the operators in a pool to show cause, again at a public hearing, why a scheme is not required to prevent waste. ${ }^{147}$

\footnotetext{
139 Id. at 65 .

140 Infra, at 179 et seq.

141 Maximum rate limitation is a general term and may include both maximum efficient rates and provisional rate limitations.

142 Report of the Operations of the Energy Resources Conservation Board, 1973, ERCB Report 74-12, Calgary, March 1974.

143 Note, for example, the definition of MER, supra, at 176.

14 The Oil and Gas Conservation Act, supra, n. 106 at s. 38.

145 Conservation in Alberta, 1973, supra, n. 105 at 10-12.

146 ld. at s. 37.

167 Communication with the Technical Assistant to the Chairman of the Board, supra, n. 125.
} 
In deciding whether to require the adoption of an enhanced recovery scheme the Board not only reviews the energy sources, reservoir rock and fluid characteristics of the pool to obtain a forecast of the increased production attributable to the scheme, but also calculates whether the scheme will allow the operator a return on his investment at prime interest rates, adjusted for risk. The assessment of risk and the appropriate compensation therefor is a matter of judgment. The Board usually considers a range of possibilities and the sensitivity of its conclusions to the assumptions upon which they are based.148

This procedure takes no account of the Crown's interest in enhanced recovery, through its royalty share. It so confirms the conclusion previously reached that the imposition of Crown royalties at high marginal rates provides a substantial disincentive to enhanced recovery. ${ }^{149}$ The portion of oil production which is attributable to the increase in reserves resulting from an enhanced recovery scheme adopted since April 1, 1974, is defined as "new oil" for the purposes of calculation of Crown royalty and thus attracts royalty on the lower scale, but this reduces the degree of the disincentive rather than removes it completely.

\section{Market Demand Prorationing}

Production of oil in Alberta is also regulated by a complex system known as market demand prorationing. ${ }^{150}$ In essence, this consists of a determination of province-wide demand for oil on a monthly basis and allocation of this demand among producing pools and wells.

During the course of Alberta's life as an oil-producing province there have been a number of different prorationing schemes in effect. The first comprehensive plan was introduced in December 1950, and remained in force until January 1958, when substantial revisions were introduced. In July 1964 a new scheme was announced which, after a transition period, was fully implemented by May 1969.151 This scheme continues to apply today, with minor amendments.

Prorationing is administered by the Energy Resources Conservation Board pursuant to powers given it by The Oil and Gas Conservation Act.152 The Board devised the present scheme, as it did with previous plans, after a series of public hearings called to review methods of prorationing. It applies to light and medium crude only. The demand for heavy oil has usually exceeded productive capacity and so curtailment of output has not been called for. Also, pools on good production practice are exempt from the plan.153

The scheme has three stages. ${ }^{154}$ The first stage entails the determination of demand for Alberta oil, by type, from all sources. This is done at monthly Board hearings when prospective purchasers submit nominations for the ensuing month. Addition of nominations gives a figure known as the provincial allowable.

\footnotetext{
148 Communication with Mr. D. R. Craig, Vice-Chairman, ERCB, Calgary, 29 January, 1974.

149 Supra, at 161.

150 The term "prorationing" is sometimes used to describe two quite distinct regulatory mechanisms, namely, Maximum Efficient Rate (or MER) prorationing and Market Demand (or MD) prorationing. The former has been mentioned, supra, $n$. 56. The latter will, for the remainder of this section, be described simply as "prorationing".

151 The history of prorationing in Alberta is recounted in detail in Watkins, supra, n. 122.

152 Supra, n. 106.

153 Report and Decision on Review of Plan for Proration of Oil to Market Demand in Alberta, OGCB Report 64 10, Calgary, July 1964 at 171 . The following description of the plan is based upon information derived from this Report.

ist The three stages are provided for specifically in The Oil and Gas Conservation Act, supra, n. 106 at 8. 34(1).
} 
The second stage consists of allocation of the provincial allowable among pools in the province capable of production of crude oil. This is done on the basis of proratable reserves. Each pool's share of the provincial allowable is determined by the ratio that the sum of its ultimate and remaining reserves bears to the sum of provincial ultimate and remaining reserves. ${ }^{155}$ If any pool is unable to produce its share of the provincial allowable, due to physical incapacity or assignment of a lower maximum rate limitation, the excess of its share over production capability is distributed among the other pools.

The third stage involves distribution of pool allocation among wells in the pool. Three different situations arise here. First, where an entire pool is subject to a unit operation, the distribution is determined by the unit agreement. Secondly, where there is no unit operation in effect and no part of the pool is subject to an enhanced recovery scheme, the distribution is performed on the basis of the area assigned to each producing well, subject to a minimum allowance or incentive allowable, where applicable. The area assigned to a producing well is the production spacing unit, made up of the drilling spacing unit together with contiguous areas under uniform ownership ${ }^{156}$ for which there is adequate geological and other evidence that the underlying oil is practically recoverable from the well. A production spacing unit is established upon application to the Board and may not exceed two and one-quarter sections. ${ }^{157}$ Thirdly, when portions of a pool are operated as units or are subject to enhanced recovery schemes while others are not, the distribution is determined according to the product of the assigned area and the recovery factor for each producing well in the pool, again subject to a minimum allowance or an incentive allowable. ${ }^{158}$ The recovery factor represents the Board's estimation of the fraction of oil in place which will ultimately be recovered from the pool, and is therefore greater when an enhanced recovery scheme is in effect. It is calculated on the assumption that the scheme is applied to the pool as a whole and this provides an incentive for extension of any scheme throughout the pool. In all cases, well allowables are subject to maximum rate limitation where this is necessary to prevent loss of ultimate recovery from the pool, and the Board imposes penalties designed to prevent undue waste of reservoir energy during production. 159

The minimum allowance operates as a floor below which a well share is not allowed to fall. If the initial distribution of a pool allocation among wells results in an allowance below this minimum, that well is given the minimum allowance and the shares of other wells are reduced accordingly. ${ }^{160}$ The minimum allowance is designed to avoid premature

155 Remaining reserves are the total reserves, recoverable by methods employed in the pool, remaining in the pool from time to time. Ultimate reserves are defined as those ultimately expected to be capable of production after all exploration and production has been completed.

136 Tracts are considered to have uniform ownership, where the ownership of the lessor's interest is the same and the ownership of the lessee's interest is the same or where all owners have agreed to pool; Report, supra, $n$. 153 at 134.

157 Id. at 179.

138 Id. at 128. If part of a pool is subject to an enhanced recovery scheme it will qualify for project status. This means that production may be taken from any part of the pool subject to the scheme, provided that ultimate recovery is unaffected. This allows similar flexibility and operating cost savings to unit development of the pool.

159 By application of gas-oil ratios and water-oil ratios, supra, n. 59.

160 Report, supra, n. 153 at 66 . This is different from the method of calculation of minimum allowances used in pre-1964 schemes. There, the minimum allowance was a basic allowance. The fraction of total pool allocation needed to satisfy minimum allowances of all wells was allocated first, and then the remainder of the pool allocation was shared among wells according to their maximum permissible rates of production (MPRs). 
abandonment of wells and to permit the completion and operation of wells drilled in low reserve per acre pools. It is therefore intended to allow recovery of completion and operating costs and to give a satisfactory return on the former. ${ }^{161}$ The size of the minimum allowance is related directly to well depth. ${ }^{162}$

The incentive allowable plan was adopted in 1972 to provide encouragement for exploratory and development drilling in pools with low reserves per acre. ${ }^{163}$ The incentive is related to proratable reserves. It has the effect of increasing the minimum allocation to wells in pools where proratable reserves are less than 2,500 barrels per acre.

The first stage of the prorationing scheme, the calculation of demand for oil on a monthly basis, assumes a given price for oil. It thus removes any incentive for producers to reduce price in order to capture a larger share of the available market. The only way in which a producer can improve his market share is to increase his productive capacity. Furthermore, the price for oil loses its responsiveness to changes in demand and supply which would otherwise cause price weakening, and therefore has a tendency to remain above what it would be if a free market were operating. ${ }^{164}$

The allocation of the provincial allowable among pools has an effect upon investment at the extensive margin. Without prorationing, it is most unlikely that all pools would share in the available market. Allocation would be performed, in effect, on the basis of marginal cost of production, and for some pools the marginal cost would exceed the market clearing price. Therefore, the prorationing scheme allows production from high-cost pools at the expense of reduced production from lowcost pools. ${ }^{165}$ Investment at the extensive margin is encouraged at the same time as there is over-capacity in other pools.

The use of reserves for allocation of production among pools is quite arbitrary, as there is no continuous relationship existing between reserves and marginal cost of production. Furthermore, the actual formula adopted by the Board for this purpose is also arbitrary. The Board recognized the disadvantages inherent in using either ultimate reserves or remaining reserves: with ultimate reserves there is a tendency for pool allocation to exceed capacity when production declines in the later years of the pool's producing life, ${ }^{166}$ whereas with remaining reserves the allocation is reduced as reserves decline, thus extending indefinitely the life of the pool.167 The Board sought to avoid the more serious aspects of both these problems by adopting a formula based on proratable reserves, a combination of the two.

There are also effects upon exploration investment, although these

161 Id. at 173. Once again, this may be contrasted with the concept of minimum allowances under pre-1964 schemes which allowed recovery of drilling as well as completion and operating costs.

162 Id. at 77. Board studies have shown that completion and operating costs vary as more or less continuous functions of depth. The allowance is 15 barrels per day for depths up to 2,400 feet, and is scaled exponentially with depth up to 65 barrels per day at 15,000 feet.

163 Report and Decision on the Application of the Independent Petroleum Association of Canada for a Discovery Allowable, ERCB Report 72-B-OG, Calgary (1972). It was suggested at the hearings, preceding adoption of this plan that it would also act as an incentive for exploration throughout the province, but this possibility was dismissed by the Board. Id. at 97.

164 For a detailed discussion of pricing in Alberta, see infra, at 194 et seq.

165 Not all high-cost pools would be placed in production, for in some cases a return would not be obtained upon investment. Nevertheless, the bias in favour of high-cost fields is apparent in the scheme. This is reinforced by the system of minimum allowances and incentive allowables.

160 Report, supra, n. 153 at 90.

$167 \mathrm{Id}$. at 111. 
appear to be contradictory. On the one hand, the allocation formula encourages exploration by reducing the risk of failure, since early production is allowed from some fields which would be extra-marginal in the absence of prorationing. On the other hand, exploration is discouraged as the rewards paid for successful effort are diminished, since production from low-cost pools is reduced below the level which would otherwise be achieved. This is another example of the bias contained in the system favouring marginal deposits at the expense of intra-marginal deposits. A further significant factor is the influence exerted by prorationing on price, which serves to encourage exploration by ensuring relative price stability at a level above that which would prevail in a free market.

Both the minimum allowance and the incentive allowable increase investment at the intensive margin, the former by ensuring the recovery of completion costs and a return thereon, and the latter by contributing to drilling costs in a specified category of pools. Otherwise, the significance of the method chosen for the distribution of total pool allocation among individual wells lies in equity rather than in efficiency considerations. The area assigned to a well is used as a proxy for the reserves recoverable from that block in the absence of drainage by adjoining wells in the pool. It is not a very accurate proxy, though, since it ignores such important factors as the volume of oil and gas bearing rocks, porosity and permeability. These may vary significantly from one part of a pool to another.

The main objectives sought to be achieved by prorationing are set out in The Oil and Gas Conservation Act: ${ }^{168}$

(a) to effect the conservation of, and to prevent the waste of, the oil, gas and crude bitumen resources of Alberta, ${ }^{169}$

(b) to afford each owner the opportunity of obtaining his share of the production of oil and gas from any pool or of any crude bitumen from any oil sands deposit.

Two problems are apparent here: the physical loss of oil resulting from wasteful production and storage practices, and the rule of capture. 170

The first of these, physical waste, has frequently been attributed to a basic instability in oil and gas pricing caused by the stochastic nature of new discoveries. The prime example quoted in support of this view is the development of the East Texas field in the 1930's when the price of oil fell to as low as ten cents per barrel and the loss of oil through dissipation of reservoir energy and ineffective storage practices was immense. To avoid such price instability and consequent physical waste, the argument runs, it is necessary to regulate price and distribute the quantity demanded at that price among producing pools. This is the justification for the first and second stages of the prorationing process.

A variation of this theory states that crude oil production exhibits decreasing costs and is thus a natural monopoly. There are unlimited economies of scale in production. Hence government regulation is required to prevent ruinous competition followed by the emergence of a

\footnotetext{
168 Supra, n. 106 at 8. 5.

160 "Conservation" is not defined. "Waste" is defined, supra, at 175.

170 The rule of capture is described supra at 173. These same two problems lay at the heart of prorationing schemes adopted earlier in the United States. Professor Eric W. Zimmermann, has noted that:

..... there are two major objectives of the present regulatory program: (1) the prevention of waste of oil and gas, through which the ultimate recovery of these products from their reservoirs is greatly increased; and (2) the protection and adjustment of correlative property rights appertaining to each owner of land in an oil and gas pool. These two objectives have become the primary aims of petroleum conservation and regulation.

Zimmermann, Conservation in the Production of Petroleum (1957) at 24.
} 
single producer. The falsity of this view has been effectively demonstrated.171 Production of oil and gas, at least after a certain point is reached, is attended by increasing marginal costs, whether considered on the basis of a single pool or an entire producing region. There is no evidence to suggest that this point at which marginal costs begin increasing is such as to give any one producer a significant share of the total market.

The random nature of discovery and size of new fields is well known, but this in itself is not sufficient to demonstrate that unregulated oil and gas production would be attended by considerable price fluctuations. These fluctuations are more likely to occur in the early stages of development of a producing region, when established markets are small in relation to the size of new discoveries; but even then there will be a time lag between initial discovery and full production from a pool, during which less violent adjustments to prices and markets can be made. Furthermore, even rapid price changes will not cause physical waste in the absence of the rule of capture so long as a future market for oil and gas is expected to be available. All that will happen is that the entry of a lower-cost producer from a newly-discovered field will cause a displacement, and temporary shut-down, of some previously profitable fields.

In the later stages of development of a producing region, the discovery of a new low-cost field is unlikely to have a significant impact on price. Rates of production from existing fields will be subject to periodic decline leaving room for the entry of a new producer. Additions to reserves and production capacity will come as much from the installation of enhanced recovery schemes as from new discoveries, and while a large new discovery may result in the delay of such installations, it will seldom do more to price than retard its inevitable increase.

The events in East Texas provide a particularly bad model for policy determination in other times or jurisdictions as they resulted from a combination of peculiar conditions which are unlikely to be repeated. The field discovered was very large in comparison with previouslyestablished reserves, ${ }^{172}$ the discovery was made at the onset of the Great Depression, and the rule of capture was in full force. The influence of this last factor, alone, seems to have been largely underestimated in explanations of the wasteful practices of this era. ${ }^{173}$

The third stage of the Alberta prorationing scheme, the distribution of pool allocation among individual wells in the pool, is designed to overcome the excesses attributable to the rule of capture. The rule is modified by the imposition of a set of well production quotas, but is otherwise left intact. ${ }^{174}$ This means that a producer must still discount user costs since

171 Adelman, supra, n. 110 at 13-44.

172 Reserves in the East Texas field were then calculated to be 2 billion barrels, more than twice the annual U.S. output: id. at 43 .

${ }^{173}$ Id. But see Ise, supra, n. 115a, who recognized this problem as early as 1926.

174 Rae, Equitable Sharing and End Use of Natural Gas, (1969) 7 Alta. L. Rev. 429. The writer describes an application made to the Gas Utilities Board, on a referral from the Oil and Gas Conservation Board, upon which the Gas Utilities Board ruled that it had no jurisdiction to order one producer to limit its total cumulative production from the Fort Saskatchewan Field, thereby leaving the other principal producer with the exclusive right to produce, when it pleased, the balance of the recoverable gas in the field. The circumstances were as follows. 'l'he principal parties were both lessee-distributors of natural gas from the field. The Conservation Board had fixed allowables for wells in the field. The respondent, Mid. Western Industrial Gas Limited, was producing its wells at rates close to these allowables while the applicant, Northwestern Utilities Limited was not, preferring to use its reserves in the field for peak load requirements. Northwestern estimated that Mid-Western's total share of the reserves in the reservoir at the time of the application consisted of XY million cubic feet, and applied to the Gas Utilities Board for an order to the effect that when MidWestern had produced XY million cubic feet it be prohibited from producing further. The Gas Utilities Board 
he will not be able to obtain more than a fraction of any present production which he defers to the future. Accordingly, oil and gas reservoirs subject to divided ownership can not be used for storage of inventories even though they provide the most efficient storage means available.

The situation in Alberta which resulted in the introduction of prorationing was caused largely by the rule of capture. Production capacity grew tremendously from 1947 to 1950 with the discovery of major oil fields at Leduc, Redwater, Joarcam, Golden Spike, Fenn Big Valley and Acheson.175 Although markets were extended into Saskatchewan, Manitoba and Ontario by displacement of United States' oil, there was excess capacity in the Alberta fields. In 1950 in the Redwater field alone, it was estimated that there was excess capacity of some 62,000 barrels per day representing $84 \%$ of Alberta's average oil production.

The rule of capture was important in the development of this excess capacity. Changes in the provincial land regulations in July, 1947, had introduced the requirement of surrender to the Crown of one half of the area under permit before conversion to a lease. This provision resulted in greater fragmentation of ownership of mineral rights in any producing field and, given the rule of capture, encouraged competitive development drilling. Imperial stated that it completed 286 producing wells in Redwater, where it owned $50 \%$ of the reservoir acreage, to meet the competition presented by twenty other companies that had acquired leases over the Crown acreage. ${ }^{176}$

Furthermore, the rule of capture led to substantial inequities among competing producers in this situation of excess capacity. In 1950 the major crude oil purchasing companies-British American and Imperialbegan limiting the amount of oil that they would take from certain fields. The share of production that an independent producer obtained from a pool thus became dependent upon the availability of a sales contract with one of the integrated companies. This was an intolerable situation for producers, and in August, 1950, Continental, a company operating wells in the Leduc-Woodbend field, applied to the Conservation Board for Imperial to be declared a common purchaser of oil from the field. Continental was under contract to sell its production to British American, which had consistently purchased lower volumes from wells than did Imperial, and Continental submitted that as a result, it had lost the opportunity to produce 46,167 barrels of oil during the period, May 1, 1949 to July 31, 1950. The Board called a hearing to consider Continental's application and the result was the adoption of the 1950 prorationing scheme. ${ }^{177}$

In these circumstances it is difficult to find any justification for the inclusion of the first and second stages of the prorationing scheme. The principal cause of industry instability was the rule of capture. To dispense with it did not require the establishment of a producers' cartel. If the Board was concerned by the market situation of many producers,

\footnotetext{
decided that such an order could not be made under the provisions of the then (November 27, 1964) Oil and Gas Conservation Act, which differs little from those of the present Energy Resources Conservation Act in this regard. Although this decision related to gas rather than oil, it has general application and provides a clear illustration of the limits of market demand prorationing in the development of oil and gas resources accor. ding to economic efficiency criteria and in achieving equity among producers in a common pool.

175 Watkins, supra, n. 122 at 57-61. The following historical account is derived from this source.

176 Dagher, Effect of the National Oil Policy on the Ontario Refining Industry, MoGill University, Unpublished Ph.D. thesio, 1968, quoted id.

in Watkins, supra, n. 122 at 73.
} 
few purchasers, and unpredictable additions to supplies (perhaps another prescription for instability), it could have taken steps to break the power of the integrated companies by requiring unitization of pools prior to production, by enforcing common purchaser requirements and, if necessary, by suggesting government entry into wellhead purchasing. It should also have suggested that the government curtail the allocation of exploration and production rights over Crown oil and gas resources while the problem of overcapacity persisted. The Board has subsequently suggested that all three stages of the prorationing scheme were necessary to achieve equity among pools, 178 but this presumes a somewhat unusual view of equity. It is not generally the rule that all resource owners are entitled, as of right, to a share of the market, nor is it clear that they should be. Usually, the market shares of resource owners are determined by their relative marginal costs of production.

What was really needed in Alberta in 1950 was a revocation of the rule of capture. The first and second stages of the prorationing scheme were not relevant to this end. The third stage did not set out to achieve it either, but merely introduced a modification to the rule designed to prevent its worst features. Complete abolition of the rule does not appear to have been seriously contemplated by the Board, although this course was available simply by requiring compulsory unitization of pools.

Today, the rapid increase in demand for oil from Alberta has almost overtaken the excess production in the province which has traditionally provided the justification for the prorationing scheme. In 1973, following the Board's review of all pools subject to the plan, only 25 were not assigned maximum rate limitations but continued to have their allowables set by market demand. It is a measure of the inefficiency of the prorationing scheme, though, that these few pools account for some 45 percent of the province's total production. ${ }^{179}$ The Board recently called a hearing ${ }^{180}$ to review the need for continuing the plan, but its report on the matter has not yet been published.

The system of market demand prorationing does not apply to gas production. Operators in the same pool may produce at whatever rate they choose, subject to the prohibition against waste, and there is no general sharing of provincial demand among pools. However, the Board has the power to see that equity is achieved among competing producers in a common pool. After conducting a public hearing, it may restrict the total amount of gas produced during any period from a pool and may distribute the total production in an equitable manner among wells in the pool, for the purpose of giving each producer the opportunity of producing or receiving his share of gas in the pool. ${ }^{181}$ However, resort to this power has seldom been necessary because of the high degree of unitization of gas pools. ${ }^{182}$

\section{Unitization}

Unitization is the process whereby a number of owners of oil and gas rights in tracts overlying a common pool or field merge their interests so that the pool or field may be operated as a single unit. In place of their

\footnotetext{
178 Report, supra, n. 153 at 20.

179 Conservation in Alberta, 1973, supra, n. 105 at 18.

380 March 27, 1974.

281 The Oil and Gas Conservation Act. supra, n. 106 at 8. 35.

182 Infra, at 186.
} 
previously-existing rights in oil and gas produced from individual tracts, the owners accept a share in the joint production from the unit. Unitization is not always complete-a number of owners may enter into such an agreement despite the fact that others with interests in the pool or field do not. However, unitization is to be distinguished from pooling where owners combine their interests simply within a drilling spacing unit.

In Alberta, the Board is charged with the duty of encouraging unitization. ${ }^{183}$ The Minister of Mines and Minerals may, with the authority of the Lieutenant Governor in Council, enter into a unit agreement on behalf of the Crown. ${ }^{184}$ The entire area of the unit, whether or not it contains some lands in which the oil and gas rights are privately owned, then becomes a location for the purposes of calculating Crown royalty, ${ }^{185}$ which is applied to actual production from all wells in the unit regardless of ownership. ${ }^{186}$ However, if the assessment of Crown royalty in this manner, using the ordinary royalty scales, gives rise to an inequitable situation or produces a substantial disincentive to unitization where this would otherwise be desirable, the Lieutenant Governor in Council may authorize the Minister to enter into a special royalty agreement applicable to the unit. ${ }^{187}$

The negotiation of unit agreements is an entirely voluntary process. The Board offers no special incentives for unit development of a pool or any portion thereof, except that which flows from a combination of unit development and enhanced recovery, in the form of an increased allocation under the prorationing scheme. ${ }^{188}$

In the case of gas pools, the natural incentives for unit development are strong. A gas plant is usually required for processing the product and individual producers will combine to make that investment. In so doing they will decide the shares in which each must contribute to costs and, as they usually correspond with entitlement to production from the pool, the major difficulty in obtaining a unit agreement is overcome. Furthermore, the method of selling gas also provides an incentive for unit development of a pool. Gas purchasers generally buy reserves, and have access to these reserves throughout the life of the purchase contract and the pool. Production is taken from the pool as required, and will often vary substantially from one season to another. The production capacity of a reservoir strongly influences its value, for, if the ability to produce is good, the reservoir may be used to meet peak load requirements. In all these circumstances, the maintenance of equity among different producers in a pool is very difficult without unit development, and so the incentive to negotiate a unit agreement is strong. Most gas pools are unitized, although in some large pools there may be a number of unit agreements in effect. Where pools cover a considerable area and reservoir rocks are thin, drainage across the pool is not usually significant. ${ }^{189}$

The incentives for voluntary unitization of oil pools are not as powerful, and as a result, unit development is not as widespread. Nevertheless,

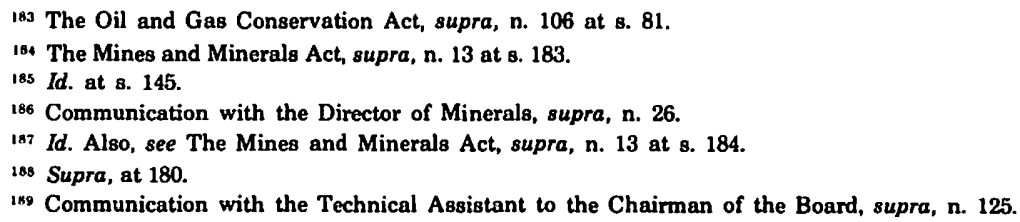


approximately 75 percent of Alberta oil production comes from unit operations or from enhanced recovery schemes to which the Board has given project status. 190

The Oil and Gas Conservation Act 191 also contains provisions for compulsory unitization where owners in a pool or field are unable to reach agreement. The Board is required to hear an application made by owners of over 50 percent of the working interests, calculated on an acreage basis, in a pool or field, and may hear an application lodged by owners of less than 50 percent of the working interests. The factor to be considered by the Board in conducting such a hearing is whether unit operation of the pool or field is desirable in the interest of conservation. If the Board determines that it is, it may, with the approval of the Lieutenant Governor in Council, and subject to a specified degree of acceptance of the proposed plan by owners of interests in the pool or field, order that the pool or field be operated as a unit. This order may contain provisions dealing with all of the issues normally contained in a unit agreement, such as appointment of the unit operator, allocation to each tract in the unit of its share of oil and gas produced from the unit, payment of the unit development and operating costs, and establishment of an operators' committee and determination of the voting interest of each member of this committee.

However, before the Board can make such an order it must obtain statements from at least 85 percent of the owners of production rights in the proposed unit area, and at least 85 percent of the owners of lessors' royalty interests in the area, signifying their acceptance of the proposed plan.

These provisions of The Oil and Gas Conservation Act have never been proclaimed, and so have not been used to achieve compulsory unitization. The government takes the view that they will only be brought into force "if necessary", and that this situation has not yet arisen, as progress with voluntary unitization has generally been satisfactory.

Unitization has a number of advantages. In the first place, it abrogates the rule of capture. In this way, it removes any necessity for the third stage, at least, of market demand prorationing as well as the regulation of well spacing. More generally, it provides the opportunity for production of oil and gas from a pool by the most efficient means, based upon reservoir characteristics rather than an arbitrary surface division of property rights: 192

Under unit operation, freedom to locate wells in conformance with the structural characteristics of the reservoirs and to utilize fully the reservoir-drive mechanism will permit more efficient recovery with fewer wells.

This is of particular significance in the continuing development of a pool as reservoir energy falls. Subject to the effects of the Crown royalty, which have already been noted, unit operation of a pool allows investment in enhanced recovery at a time and to a degree calculated to produce the maximum present value of production. Divided ownership, on the other hand, even when prorationing is in effect, operates as a disincentive to such investment as each operator is aware that he will be unable to derive the full benefits therefrom.

\footnotetext{
$190 \mathrm{Id}$.

191 Supra, n. 106 at 88. 87.95.

192 Interstate Oil Compact Commission. A Study of Conservation of Oil and Gas in the United States (1964) at 57.
} 
The difficulty encountered in unitization is the reconciliation of the different property interests in a producing pool. These interests may be very numerous, and the costs incurred in reaching a voluntary agreement may be substantial. The case for and against unit development, therefore, depends largely upon the attitude adopted toward private rights. If such rights may be ignored then unitization should be adopted in every case. If private property rights are to be respected, unitization of a pool or field should only be required when the benefits to be derived from unit operation exceed the transactions costs incurred in establishing the unit.

Transactions costs increase with the number of parties involved in the negotiations. Therefore, the fragmentation of ownership which results from the two-stage allocation system of rights over Crown oil and gas resources, with the requirement of surrender of at least 50 percent of reservation areas upon conversion to lease and the further allocation of these Crown reserves to competing operators, inevitably makes unitization more difficult.

Transactions costs could also be reduced by a system of compulsory unitization. At one extreme would be a system of unitization by government decree. An alternative is the Alberta system of compulsory unitization, not yet in force. The hearing procedure and requirement of acceptance by large majorities of the different interest owners add to transactions costs, but are undoubtedly included to provide a measure of protection for private rights. The compromise reached between transactions costs and protection of private rights is clear.

The advantages to be obtained from unit development of pools have long been recognized in Alberta. The 1940 Royal Commission on Alberta's Oil Industry reported, ${ }^{193}$ firstly;

that the ideal Conservation is attained only under unit operation,

and secondly,

that in the absence of unit operation, the compromise measure of Conservation and Proration law must be accepted.

It is not clear why the Board, in recommending market demand prorationing in 1950, rejected the solution of unitization. Perhaps it was as a result of a very strong regard for the sanctity of private rights in oil and gas. If so, the Board's faith in prorationing was somewhat misplaced. Neither the present prorationing scheme nor its predecessors attempted to achieve absolute equity among competing owners of oil and gas rights. The present scheme, as has already been noted, bases allocation of production within pools principally upon the surface area of rights held, without consideration of the volume or producibility of reserves. ${ }^{194}$

\section{TRANSPORTATION}

Both the building and the operation of pipelines are regulated by The Pipe Line Act,195 which applies to all pipelines in Alberta except those situated wholly within the property of a refinery or other plant, and

193 Harrison, supra, n. 112 at 368.

194 Supra, at 180.

195 R.S.A. 1970, c.275, as amended by S.A. 1971 , c.30 and S.A. 1972, c.91. 
those subject to the jurisdiction of the National Energy Board. ${ }^{196}$ A permit is required for the construction of an oil or gas line. ${ }^{197}$ An application for a permit is made to the Energy Resources Conservation Board which is empowered to grant permits subject to such terms and conditions as the Board may see fit. A licence is required for the operation of a pipeline. ${ }^{198}$ Licences may be granted by the Superintendent of Pipe Lines after plans and specifications of the line have been filed with the Board.

There are important differences between the operations of oil and gas pipelines. An oil pipeline is generally a carrier only; it takes oil owned by others and delivers it to refineries. It does not purchase the oil but charges a fee for carriage. There is some degree of competition possible from other modes of transport, such as rail, truck or ship. The gas pipeline is faced with competition from liquefaction only, a relatively recent and expensive process. The pipeline operator is usually in the position of a monopoly purchaser, who then transmits the gas, which is sold on long term contract. The regulation of pipelines in Alberta has reflected these differences.

Applications for permits to construct oil lines in Alberta have been considered by reference to the financial and technical ability of the applicants, and the government has not been concerned to prevent duplication of facilities. ${ }^{199}$ On the contrary, competition among pipeline operators has been looked upon favourably as a means of preventing transportation charges from becoming excessive.

Discrimination by pipeline operators among different oil producers may be avoided under The Oil and Gas Conservation Act. ${ }^{200}$ The Board has the power, upon application and after a hearing, to declare the operator of a pipeline to be a common carrier. The operator is then prohibited from discrimination of any kind as between producers, and especially as between any oil in which he is indirectly interested and that of independent producers. ${ }^{201}$ Moreover, once a pipeline operator has been declared a common carrier, if an agreement cannot be reached between the operator and any person wishing to have oil carried in the pipelines as to the tariff to be charged for this service, an application may be made to the Public Utilities Board to fix the tariff. ${ }^{202}$ However, resort to these provisions has been very infrequent. The market demand prorationing scheme has meant that discrimination among producers on the basis of volume of oil carried is most unlikely, and there appear to have been few instances of discrimination on the basis of carrying charges.

So far as gas pipelines are concerned, two quite different situations arise, depending upon whether the gas is destined for consumption within or outside Alberta. Gas used within the province is purchased

\footnotetext{
198 Id. at 8. 4. The Lines subject to the jurisdiction of the National Energy Board are described in Crommelin, Studies in Government Management of Oil and Gas in Canada, (1975) 10 U.B.C. L. Rev.

197 Id. at s9. 5-12. Since January 1, 1972, the administration of the Act has been entrusted to the Energy Resources Conservation Board, in place of the Department of Mines and Minerals.

198 Id. at ss. 14-16.

199 Olisa, Government Control of Oil and Gas Pipe Lines in Alberta (1967) 5 Alta. L. Rev. 226. There has been no noticeable shift in this policy since the administration of The Pipe Line Act passed to the Board in 1971.

200 Supra, n. 106.

201 Id. at s. 49.

202 Id. at 8. 56 .
} 
from producers by the gas utility companies who own and operate their own transmission systems. Gas which is to be removed from the province is collected by the Alberta Gas Trunk Line Company Limited and carried to various border points where it passes into the transmission systems of the principal exporters from the province.

The Alberta Gas Trunk Line Company Limited was incorporated in 1954 by a special Act of the Alberta Legislature. ${ }^{203}$ The capital stock of the company is divided into class " $A$ " common shares, available for purchase by private investors, 204 and class " $B$ " common shares, which are restricted to gas utility, export and producing companies . Four directors are appointed by the Lieutenant Governor in Council, four are elected by the holders of class " $\mathrm{B}$ " common shares, and seven by the holders of class " $A$ " common shares. All must be Canadian citizens and residents of Alberta. ${ }^{205}$ The holders of class " $A$ " common shares have no voting rights. ${ }^{206}$

Since 1954, the Alberta Gas Trunk Line Company Limited has had an effective monopoly over the construction and operation of all pipelines carrying gas for removal from the province. This has prevented any duplication of facilities. The monopoly has been maintained by the insertion of a condition in all permits issued for removal of gas from the province, stating that the permit holder will use only the facilities of the Alberta Gas Trunk Line Company Limited.207

The company operates as a carrier of gas only, and not as a buyer and seller. It has the power to fix charges for transportation and other services performed. These may be reviewed by the Public Utilities Board upon application by an interested party or upon the direction of the Lieutenant Governor in Council, ${ }^{208}$ In practice the company is paid transportation charges on a cost of service basis which includes operating expenses, income and other taxes, and depreciation of pipeline and plant facilities, together with an annual return on its rate base which is composed of the depreciated investment in plant and an allowance for working capital. ${ }^{209}$

In the case of gas as well as oil pipeline operators, The Oil and Gas Conservation Act provides for common purchaser, common processor and common carrier orders.210 The only recent common carrier application for gas was in 1963, when an order was made declaring Cretaceous

203 The Alberta Gas Trunk Line Company Act, S.A. 1954, c.37, since amended by S.A. 1955, c.38, S.A. 1959, c.25 S.A. 1962 , c.27, S.A. 1964, c.3, S.A. 1966, c.3, S.A. 1970, c.5, S.A. 1971, c.30, S.A. 1972, c.8, S.A. 1973 , c.4 and S.A. 1974, c.7.

204 In 1973, there were $16,800,000$ class " $A$ " common shares on issue, which were held:

(a) as to 45 per cent by some 22,000 individual Canadian investors, of whom 15,000 were resident in Alberta

(b) as to 53 per cent by Canadian institutional investors whose beneficial or nominee holdings were estimated to be over 90 per cent by or for Canadians, and

(c) as to 2 per cent by foreign investors.

Annual Report 1973 at 2.

205 The Alberta Gas Trunk Line Company Act, supra, n. 203 at 88. 18, 19.

206 Id. at B. 5 (c).

207 For example, the condition inserted in the permit issued to Pan-Alberta Gas Ltd. in February 1974 reads as follows:

The Permittee shall remove or cause to be removed pursuant to this Permit only such gas as is delivered to it through facilities of The Alberta Gas Trunk Line Company Limited at the interconnections of their pipe lines....

In the Matter of an Application of Pan-Alberta Gas Ltd. under The Gas Resources Preservation Act, ERCB Report 74-D, Appendix F-6, Calgary, February, 1974.

208 The Alberta Gas Trunk Line Company Act, supra, n. 203 at s. 30.

209 Annual Report, 1973 at 12 . It is interesting to note that, prior to 1973 , the company was able to defer all in. come taxes and pass the full savings thereof on to its customers. In 1973, a charge was made for a portion of these deferred taxes, resulting in an increase of $\$ 5.9$ million in transportation charges. Id. at 13.

210 Supra, n. 106 at $88.49-56$. 
Pipelines Limited a common carrier from the Willingdon Field and the Hairy Hill Field. The applicant demonstrated that it had an adequate supply of gas, that there was an existing market, and that attempts to negotiate with the operators of the pipeline for the use of the line had failed. The Board granted the application after consideration of the economics of alternatives to the proposed order. It has been suggested that this is an acknowledgment that the Board is principally concerned with achieving equity among competing producers in a common pool. ${ }^{211}$ There have been five common purchaser applications in Alberta, and a review of these has also shown that the Board has regarded its primary function as one of achieving equity among competing producers. ${ }^{212}$

On the whole, therefore, government regulation of transportation of oil and gas in Alberta has been directed toward leaving these activities in the hands of private enterprise, while preventing abuse of the natural monopoly position enjoyed by a pipeline operator. This is best exemplified by the situation of oil pipelines. The formation of the Alberta Gas Trunk Line Company was probably motivated as much by the government's desire to maintain control over the removal of gas from the province ${ }^{213}$ as by the possibility of preventing duplication of facilities and exploitation of monopoly power.

\section{EXPORTS}

The export from Alberta of natural gas is controlled by The Gas Resources Preservation Act. ${ }^{214}$ The object of this Act is:215

to effect the preservation and conservation of the oil and gas resources of the Province belonging to the Crown in right of Alberta and to provide for their effective utilization having regard to the present and future needs of persons within the Province.

Any person wishing to remove gas from Alberta is required to apply to the Energy Resources Conservation Board for a permit. The Board will usually conduct a hearing on the matter. It may not grant a permit unless it is of the opinion that it is in the public interest to do so, having regard to the present and future needs of persons within Alberta and the established reserves and the trends in growth and discovery of reserves of gas in Alberta. The grant of a permit by the Board is subject to the approval of the Lieutenant Governor in Council. The Board may include such terms and conditions in the permit as it sees fit, and in particular may specify (a) the pool, field or area, and the point on a pipeline or processing plant, from which gas may be removed, (b) the annual quantities of gas that may be removed from each location, (c) the maximum quantity of gas that may be removed daily from each location, (d) the conditions under which the removal of gas may be interrupted, (e) a requirement that the permit holder supply gas at a reasonable price to any community or consumer in Alberta that can reasonably be supplied by the permit holder, and (f) the duration of the permit. In the event of an unforeseen emergency which jeopardizes the supply of gas to consumers in Alberta, the Board may, with the approval of the Lieutenant Gover-

\footnotetext{
211 Hebb, Common Carrier, Common Purchaser, and Common Processor Orders (1969) 7 Altta. L. Rev. 436 at 440.

212 Id. at $438-442$.

213 Discussed infra.

214 R.S.A. 1970, c.157, as amended by S.A. 1971, c.30, S.A. 1972, c.44 and S.A. 1973, c.90. The Act also applies to propane.

215 Id. at 8. 3. Prior to 1973 the Act applied to all gas produced in the province. An amendment in that year (S.A. 1973, c.90) restricted the application to production from Crown lease, licence or reservation, Id. at 8. 2.1 .
} 
nor in Council, adjust the allowable rates of production of gas from any well, pool or field or require the diversion of any gas intended for industrial use outside Alberta to such other uses as the Board may direct. ${ }^{216}$ The Board may cancel a permit for failure to comply with any of its terms or conditions or for contravention of any provision of the Act. ${ }^{217}$

In general terms the procedure adopted by the Board in considering an application for a permit is as follows: ${ }^{218}$

Firstly, it estimates the proved reserves of gas in the province.

Secondly, it analyses and projects the trends in the growth of reserves of gas in the province.

Thirdly, it estimates the gas requirements of the province for the ensuing thirty-year period.

Fourthly, it calculates the gas necessary to meet the annual and peak day requirements of the province for a thirty-year period and to meet existing permit requirements.

Finally, it analyses the surplus position of the province for gas having regard to the proved reserves, the growth in reserves, the thirty-year requirements and the existing permit commitments.

The Board's estimate of proved reserves is derived from Board reservoir data and makes use of submissions made by industry at various hearings during each year. It is published annually in the Board's report on reserves of crude oil, gas, natural gas liquids and sulphur. ${ }^{219}$ The growth rate in reserves projected by the Board will not exceed the average rate experienced over the previous ten years and may be below that where a decline has been noticed in more recent years. The number of years for which growth is anticipated is calculated by reference to the excess of ultimate reserves over proved reserves. ${ }^{220}$ The gas requirements of the province are estimated following periodic hearings on the subject of Alberta's requirements of energy and energy resources. ${ }^{221}$ In assessing the surplus position of the Province, the Board divides requirements and reserves into two categories: contractable and remaining. Contractable requirements are the total of the Alberta requirements which would normally be under contract to utility companies or large industries and the existing export permit commitments. Remaining requirements include those for delivery to meet local needs in the latter portion of the thirtyyear period plus the gas necessary to sustain peak deliveries in the terminal year. Contractable reserves are those available for delivery now or in the near future which are under contract or are available for contract.

218 Id. at s8. 4-9. In certain circumstances the Board may, with the approval of the Lieutenant Governor in Council, grant a permit for the export of limited quantities of gas or propane without conducting a hearing; Id. at B. 12. The removal of propane from the Province otherwise than by pipeline is not subject to permit; id. at 8 . 24, and Alta. Reg. 285/65 (1965).

217 Id. at 8. 13.

218 Report and Decision on Review of Policies and Procedures for Considering Applications under The Gas Resources Preservation Act (1966), Calgary, OGCB Report 69-D, October 1969 at 2.

219 See, for example, Reserves of Crude Oil Gas, Natural Gas Liquids and Sulphur, Province of Alberta, ERCB Report 74-18, Calgary, December 31, 1973.

220 The formula employed is:

$T_{G}=\frac{R_{U L T} \cdot R_{P R}}{10}$

where $T_{G}=$ years of reliance upon future gas reserves;

RULT = Marketable reserves ultimately expected after all exploration and production has been completed; $\mathbf{R}_{\mathrm{PR}}=$ Proved marketable reserves at the time of application of the formula.

${ }^{221}$ See, for example, Interim Report on Alberta's Requirements of Energy and Energy Resources, 1972-2001, ERCB Report 73-0, Calgary, November 1973, and the Appendix thereto, ERCB Report 74-F, Calgary, March 1974. This is the report of the first such hearing, held Setptember 1972, and resumed during the spring of 1974. Previously, requirements hearings were in relation to gas only; Report and Decision Regarding Alber. ta's Furture Requirements of Gas, OGCB Report 71-B, Calgary, February 1971. 
Remaining and future reserves include those currently beyond economic reach, those where production has been deferred but can be expected within thirty years, and those not yet discovered or developed but which the Board anticipates will be developed within the near future. The Board requires an applicant for a permit to demonstrate the existence of both a contractable surplus and a remaining and future surplus. ${ }^{222}$ The duration of permits usually matches that of the gas purchase contracts, up to a maximum of twenty-five years.

The effect of the Board's procedure in considering applications to remove gas from the province is to require the maintenance of an inventory of gas reserves at a specified level. Since the period of thirty years during which Alberta's needs must be met is very much longer than the lead time required for discovery, development and production of new reserves, this inventory involves a cost to Alberta in the form of premature exploration and development expenditures.223 Moreover, the dual requirement of showing both a contractable surplus and a remaining and future surplus makes this inventory larger than it would otherwise be if calculated simply to meet Alberta's thirty-year needs. A contractable surplus is dependent upon proved reserves, which provides an incentive to develop reserves in order to bring them within this narrow category. 224

Furthermore, the precision implicit in the Board's determination of an exportable surplus is rather deceptive, for the calculations ignore, in one important respect, the influence of price. In a recent report upon an application to remove gas from the province, the Board did recognize the impact that recent price increases for gas have had upon reserves, and allowed an increase in recoverable reserves based upon a study of individual pools. ${ }^{225}$ However, price seems to have been overlooked in the Board's assessment of Alberta's future requirements. ${ }^{226}$ It must be conceded, of course, that future gas prices are very difficult to estimate and that the relationship between price and demand is uncertain. Nevertheless, the failure to incorporate the possibility of price changes

222 Report, supra, n. 218 at 2-3. More precisely, the existence or otherwise of a contractable surplus is determined by a comparison of the contractable reserves and the contractable requirements. The former are the proved reserves within economic reach, less a portion of any reserves from which production is deferred by reason of oil production or cycling operations. The Board is prepared to recognized a portion of a deferred reserve as contractable if its time of initial production can be anticipated with a reasonable degree of certainty. The amount of a reserve classified as such depends upon expected production from the reserve during the thirty. year period, or, if the reserve is under contract, the part of the reserve actually covered by contract which is expected to be delivered during the term of the permit. Contractable Alberta requirements are measured by the greater of thirty times the requirement of the first year of the period under consideration, or the remaining reserves in those fields committed to and supplying Alberta's needs. The existence or otherwise of a remaining and future surplus is determined by a comparison of the remaining Alberta requirements and the remaining and future reserves. The former are the total requirements less the reserves classified as contractable. Two types of requirements are distinguished: thase which will actually be delivered for use during the thirty-year period, and those needed only to maintain peak day demand in the final year. The remaining and future reserves are the portion of reserves now beyond economic reach which the Board estimates will be within economic reach within the thirty-year period, the portion of deferred reserves not included in contractable reserves which will become available within the thirty years, and the projected growth in reserves.

223 It has been estimated by the Canadian Petroleum Association that the average before tax cost to the gas producing industry of carrying an unsold developed inventory of one trillion cubic feet of gas for one year would be approximately 3.3 million dollars; $i d$. at 7 . This is a measure of private cost, however, and is quite different from the social cost of early investment in exploration and development.

224 Reserves need not be fully developed to qualify as proved, however. The definition of proved reserves adopted by the Board is "those reserves specifically delineated by drilling, ditching, running audits, testing or producing, plus a judgment portion of those further contiguous reserves which are generally delineated by geological seismic or similar information and which can be reasonably counted upon." Reserves of Crude Oil Gas, Natural Gas Liquids and Sulphur, Province of Alberta. ERCB Report 74-18, Calgary, December 31, 1973, supra, n. 219 at $1-3$.

225 In the Matter of an Application of Pan-Alberta Gas Ltd. under The Gas Resources Preservation Act, ERCB Report 7A-D, Calgary, February 1974 at 8.5

238 Interim Report, supra, n. 221. 
in the Board's assessment of future requirements makes the entire calculation of an exportable surplus little more than a mechanical exercise.

Finally, it must be remembered that the Board's duty under The Gas Resources Preservation Act ${ }^{227}$ is to decide whether or not it is in the public interest to allow removal of gas from Alberta. ${ }^{228}$ The Board has consistently taken a narrow view of what constitutes the public interest, relying upon the words in the Act which say that the public interest must be viewed having regard to "the present and future needs of persons within the Province" and "the established reserves and the trends in growth and discovery of reserves of gas or propane in the Province."229 Whether or not the Board is correct in interpreting this as meaning that the public interest is restricted to ensuring future availability of gas, it is clear that efficient management of Crown resources requires a broader approach. If controls are to be placed upon the removal of gas from Alberta, the Board should be charged with the duty of evaluating applications according to whether they produce a net social benefit to the province. This would require an assessment of all the social benefits and costs arising from the proposed export, including the costs of maintaining an inventory, the benefits attributable to security of supply for a number of years into the future, and the social opportunity costs of present export and sale. 230

By way of comparison, it is noted that a recent amendment ${ }^{231}$ to The Oil and Gas Conservation Act gives the Board control over certain end uses of gas in Alberta. A permit, known as an industrial development permit, is required from the Board before any gas may be used as a raw material or fuel in the production of carbon black, ammonia, urea, ethanol, methanol or any petro-chemical product. The authorization of the Lieutenant Governor in Council must also be obtained. The Act states that the Board shall not grant such a permit unless it is in the public interest to do so having regard to, among other considerations:

(a) the efficient use without waste of gas or gas products, and

(b) the present and future availability of hydrocarbons in Alberta.

It remains to be seen whether this section will lead the Board into the area of calculation of net social benefits from industrial activity in the province.

\section{PRICING}

Until recently, the wellhead price of Alberta oil has been set by reference to the prices of alternative sources of supply in North America. In general terms, the pricing system for oil in North America is a netback or basing-point system. Market prices are set by the location of a

227 Supra, n. 214.

228 Id. at s. $7(3)$.

220 Id.

230 These opportunity costs would usually be represented by the present value of deferral of exports to the most favourable time in the future. It is interesting to notice that Pan-Alberta Gas Ltd. urged the Board to take a broader view of "public interest" in its recent application for an export permit. Pan-Alberta referred to such factors as the right of the public to participate in the company, the proposal to fund a research institute in the province, the right to replace the gas to be removed from Alberta, and the like. The Board considered these items, and others, but reaffirmed its view that its "primary responsibility" was in relation to future supplies. In the Matter of an Application of Pan-Alberta Gas Ltd. under The Gas Resources Preservation Act, supra, n. 207 at s. 11. More recently, the British Columbia Energy Commission has suggested to the National Energy Board that the NEB adopt the broad approach to "public interest" in its consideration of gas exports from Canada to the United States.

231 The Oil and Gas Conservation Amendment Act, S.A. 1974, c.48, replacing 8. 42 of the principal Act. 
competitive "interface" where the delivered costs of oil transported from various sources of supply are equalized. The wellhead price is then fixed by deduction of transportation cost to that area. This method of pricing is bolstered when, as in Alberta, supply within a source area is controlled by regulation such as market demand prorationing, since competition between alternative supplies from the same area is eliminated. ${ }^{232}$

The expansion of markets for Alberta oil since the Leduc discovery in 1947 required frequent adjustments in wellhead prices to meet competition from sources of supply in the United States, which had previously served areas penetrated by Alberta oil. Up until March 1959, the Sarnia area tended to be the market equalization point for competing sources of supply; however, subsequently this moved south to the Detroit-Toledo area of the United States. Since 1961 the National Oil Policy has reserved the Canadian market west of the Ottawa Valley for domestic crude, lending stability to prices by removing the threat of foreign competition in the region..$^{232}$ arom 1962 to 1970 there was little change in either market conditions or price for Alberta oil..233

After 1970, as United States domestic sources of supply found increasing difficulty in meeting the fast-rising demand for oil, Alberta suppliers increased their penetration as far as the Chicago market. At this time the major curb upon further expansion was the quota imposed under the United States oil import programme. Despite increased transportation costs to Chicago, Alberta wellhead prices increased steadily during these years in response to the stronger demand.

In September, 1973, this traditional pattern was broken. The price of oil in the Chicago market started to rise sharply, reflecting supply difficulties in the United States, higher prices in the international market and the Middle East conflict. Prime Minister Trudeau announced a voluntary price freeze on oil in Canada supported by an export tax on oil sold to the United States. The average wellhead price for Alberta oil at this time was approximately $\$ 3.80$ per barrel and the export tax was set initially at 404 per barrel, the difference between Canadian and United States prices. The tax subsequently rose to a peak of $\$ 6.40$ per barrel as United States prices continued to increase. ${ }^{234}$

The Alberta government strenuously opposed both the domestic price freeze and the export tax. At a federal-provincial First Ministers Conference in January, 1974, an agreement was reached to continue the freeze until April 1, in exchange for the remittance of 50 per cent of the proceeds of the export tax to the oil producing provinces. At a further such meeting in April, a new arrangement was worked out whereby the wellhead price of oil would rise by $\$ 2.70$ per barrel, the export tax would be reduced correspondingly, and the federal government would retain all the revenues raised by the tax. The increase in wellhead prices for oil took effect on April 1,1974, and the revised royalty schedules for oil introduced by the Alberta government also took effect on that date. ${ }^{235}$ The

\footnotetext{
232 Watkins supra, n. 122 at 114-115.

232a This policy was adopted following the Second Report of the Royal Commission on Energy (July, 1959).

223 Watkins, supra, n. 122 at $115-116$. The price of Redwater oil remained at $\$ 2.60$ per barrel from May 1962 until 1970. The price of oil from other fields varied slightly according to transportation and quality differentials.

234 The legislation imposing the tax was not passed by Parliament until January, 1974. It was then made retroactive to October 1, 1973: Oil Export Tax Act, S.C., 1974, c.53. Prior to the enactment of the legislation the tax was effectively imposed by the National Energy Board which advised United States purchasers of oil that export permits for October (and following months) would not be granted unless the price rose by the amount of the announced tax, which was to be collected subsequently by the federal government.

235 Supra, at 154.
} 
new prices were to remain unchanged for a period of twelve to fifteen months when, it was anticipated, another series of federal-provincial discussions on oil prices would take place.

In December, 1973, the Alberta Legislature passed The Petroleum Marketing Act, ${ }^{236}$ which established the Alberta Petroleum Marketing Commission, a Crown corporation consisting of three members appointed by the Lieutenant Governor in Council. The Commission has a number of broad powers relating to the pricing of oil produced from Crown leases in Alberta. ${ }^{237}$ First, the Commission may accept the Crown royalty share of production, in kind, whereupon it is charged with the duty of selling this oil within Alberta at a price that is "in the public interest of Alberta".238 Secondly, the Commission is appointed the exclusive agent to sell the lessee's share of production on behalf of the owner thereof, and is required to obtain the highest price that it may reasonably negotiate having regard to the market conditions prevailing at the time of the sale. ${ }^{239}$ The Commission has been in operation since March 1, 1974, but to date has confined its operations to publication of monthly bulletins listing wellhead prices for oil produced from all pools in which the Crown has mineral interests and requiring producers to report quantities of oil sold and prices received therefor on a monthly basis. The prices stipulated by the Commission are based directly upon the prices agreed upon at the federal-provincial conferences, subject to quality and transportation cost differentials. In fact, therefore, wellhead prices of oil in Alberta are currently fixed by reference to the most recent federal-provincial agreement, and the Commission amounts to no more than a mechanism which might be used in the future to control prices. However, there is some doubt as to the constitutional validity of The Petroleum Marketing Act in so far as it purports to give the Commission power over the price of oil destined for the interprovincial and international markets. ${ }^{240}$

Alberta gas is purchased on long term contract, the term of which is usually between twenty and twenty-five years. The price paid for gas at any time during this term depends upon a number of factors. The base price is the price paid by the buyer during the early years of the term. The majority of contracts provide for periodic escalation in price, intended to cover increases in production costs and to recognize the purchaser's ability to pay higher prices as pipeline systems become more fully loaded and partially paid for. Frequently, also, contracts include a price redetermination clause which provides for renegotiation of both the base price and any escalation provision at specified times during the life of the contract. Finally, some contracts contain a favoured nation clause which requires the purchaser to meet more favourable terms if they are offered to other sellers in a defined locality. ${ }^{241}$

The number of purchasers of gas in Alberta has always been limited. The Alberta utilities companies buy some of their requirements in the field, but also acquire reserves directly from which they can service their

\footnotetext{
236 S.A. 1973, c.96.

2:37 The Act also provides that the Lieutenant Governor in Council may make regulations for the establishment of a scheme or plan for the marketing of all oil produced in Alberta, but these provisions have not been proclaimed: id. at 8.24 .

$238 \mathrm{Id}$. at 8. 15.

239 Id. at 8. 21 .

240 For a discussion of the constitutional validity of this legislation, see Crommelin, supra, n. 196, Part I at 81 et seq.

241 Field Pricing of Gas in Alberta, supra, n. 6 at 8. 4.
} 
needs as they arise. From 1955 to 1957, Trans-Canada Pipe Lines Limited was the sole major purchaser of gas for removal from the province. At this time the base price was about 10 cents per thousand cubic feet (Mcf). This price increased sharply by some 3.5 cents per Mcf in 1958 when Alberta and Southern Gas Co. Ltd. began contracting for gas. However, the practice developed whereby Trans-Canada bought gas in the plains region of the province and Alberta and Southern acquired supplies in the foothills region, so that the two extra-provincial buyers rarely competed in the same field. The result was that from 1958 to 1968, base prices remained nearly constant, in the range of 13 to 14 cents per Mcf. During 1969 and 1970, an abrupt increase of 4 cents per Mcf coincided with the introduction of a new buyer of gas for removal from the province, Consolidated Natural Gas Limited. By 1972, the base price offered by Trans-Canada had increased gradually to 19 cents per Mcf..242 However, in 1971 this new element of competion was effectively removed by the refusal of the National Energy Board to allow Consolidated to export its gas to the United States. ${ }^{243}$ Consolidated discontinued its purchasing activities and there was a clear indication that the price increases of the previous years would immediately level off.

In February, 1972, the Lieutenant Governor in Council requested the Energy Resources Conservation Board to make an inquiry and investigation into the field pricing of gas and to advise him on:244

(a) factors which influence field prices for natural gas and their suitability in the Alberta public interest,

(b) the pricing provisions of present contracts for the purchase of natural gas for marketing outside the Province and their suitability in the Alberta public interest,

(c) present and anticipated field prices of natural gas in Alberta and their suitability in the Alberta public interest,

(d) possible modifications or alternatives to current practice affecting field price which would enhance the benefit to all residents of the Province.

The Board conducted a hearing on the matter and delivered its report in August, 1972. It found that it was in the Alberta public interest for field prices of gas to be increased to the field equivalent of the "commodity value" of the gas in its market areas. The most important factor influencing Alberta gas prices was the degree of competition in purchasing in the field. Essentially all gas under purchase contracts for removal from the province was subject to price escalation, but the average rate of escalation of one-quarter of a cent per Mcf per year was too low. Some 85 per cent of the gas reserves under contract for removal from the province was subject to price redetermination, but only 30 per cent was subject to favoured nation provisions. The average field price for gas in Alberta was about 16 cents per Mcf, which the Board considered to be at least 10 cents below the value determined by the Alberta public interest. It recommended that the government take steps to ensure adequate competition in purchasing of gas in the future, and that all contracts provide for a base price consistent with the "commodity value" of gas, a regular price escalation of some 3 to 4 per cent in the base price per year, price redetermination as frequently as possible and at least every five years, and immediate price redetermination if action by the Canadian government or the exporter resulted in an increased export price for gas. It also

242 Id. at 8. 7.1.

243 Reasons for the Decision in the Matter of an Application under the National Energy Board Act of Consolidated Natural Gas Limited et al., National Energy Board, Ottawa, November 1971.

24 O.C. 204/72, February 16, 1972. 
suggested that when the price of gas fixed under existing contracts came up for redetermination, the new price would be fixed by reference to the "commodity value" of gas. Where contracts did not include a redetermination provision, the Board did not feel that direct government intervention was warranted, but that purchasers of gas for extraprovincial markets should be required to file with the Board particulars of the pricing provisions of all new and amended contracts, so that the Board would be in a position to assess whether they were in the Alberta public interest. ${ }^{245}$

The Alberta government accepted the Board's findings and recommendations, with only minor variations. It stated that the government took a strong position in support of higher prices for gas leaving the province, that price redetermination should be on a two-year rather than a five-year basis, and that the Board would be required to provide the government with annual progress reports on the extent to which new and amended contracts reflected the pricing provisions endorsed by it. ${ }^{246}$ The government also made it clear, indirectly, that purchasers of gas for removal from the province would not obtain permits for export of increased volumes unless all purchase contracts, both existing and future, conformed with government price requirements.

In July, 1972, a new element of competition entered into the purchasing of gas in Alberta. The Alberta Gas Trunk Line Company Limited incorporated a wholly-owned subsidiary, Pan-Alberta Gas Ltd., with the object of purchasing gas for a six-year term for export to the United States. It was intended that this gas would be replaced, beginning in 1980, with gas from Prudhoe Bay and the Mackenzie Delta so that no longer term shortages would result in Alberta. The price offered by PanAlberta to producers was 40 cents per Mcf, double the price then offered by Trans-Canada and Alberta and Southern. In a short space of time, Pan Alberta succeeded in obtaining contracts for more than a trillion cubic feet of gas. ${ }^{247}$ In December 1973, the Alberta Energy Company, a provincial Crown corporation established in September of that year to provide an opportunity for direct public investment in Alberta energy resources on a partnership basis with the Alberta government, acquired 50 per cent of the shares in Pan-Alberta. ${ }^{248}$

In July, 1973, the Board reviewed the position in Alberta with respect to the pricing of gas. ${ }^{249}$ It found that the field equivalent of the commodity value of gas had increased to at least 27 to 38 cents per Mcf due to inflation and inter-fuel competition, that new contracts had been executed or were under negotiation for some 52 per cent of the remaining gas under contract for removal from the province, and that the 1973 average field price of gas was 20 cents per Mcf, an increase of 3.5 cents over the average price for 1972, but still 7 to 18 cents per Mcf below the Board's estimate of field value.

More recently, the Alberta government has taken direct action to

245 Field Pricing of Gas in Alberta, supra, n. 6 at 8. 11.

246 Alberta Government Statement of New Natural Gas Policies for Albertans, November 16, 1972.

247 Communication with R. S. Gibbs, Q.C., President of Pan-Alberta Gas Ltd., Calgary, 25 July, 1974.

248 Oilweek, December 17, 1973 at 11. The Alberta Energy Company has not yet offered shares for public subscription. In addition ot its interest in Pan-Alberta, it is intended that it should have an option to acquire a 20 per cent interest in the Syncrude oil sands project, control the oil sands common carrier pipeline, and develop the Suffield gas reserves: Communication with Dr. G. B. Mellon, Deputy.Minister, Department of Mines and Minerals, Edmonton, 23 July, 1974.

249 Review of Field Pricing of Gas in Alberta, ERCB Report 73-1-OG, Calgary, July, 1973. 
achieve increases in gas prices. In January, 1974, Premier Lougheed announced that Alberta and Southern had agreed to offer producers an average price of 56 cents per Mcf for the 1.2 billion cubic feet a day of gas carried by it, representing 27 per cent of all gas leaving the province. The Premier stated that Alberta and Southern's action was in response to a direct approach made by his government to the company. ${ }^{250}$

In December, 1973, the Alberta Legislature amended The Arbitration Act, ${ }^{251}$ by the addition of a new section governing the redetermination of the purchase price of gas by arbitration. ${ }^{252}$ Wherever there is a submission to arbitration, under a gas purchase contract, of a price redetermination, the arbitrators are required to determine the field value of gas and to use that value in fixing the redetermined price of gas. The "field value" of gas is defined as:

the commodity value of gas less just and reasonable costs, charges and deductions that are or may be fixed, determined or allowed for the transportation and distribution of that gas from the point of sale under the gas purchase contract to the point of end use.

The "commodity value" of gas is defined as:

(i) the thermal value of gas determined by reference to the volume-weighted average prices of substitutable energy sources competing with gas for the various end uses of gas in the consuming markets served, directly or through exchange, by the buyer of gas under a gas purchase contract, and

(ii) the premium value of gas determined by reference to its inherent special qualities when compared with competing energy sources.

There are both Canadian citizenship and Alberta residency requirements for arbitrators. Moreover, arbitration may be commenced by one party to a gas purchase contract irrespective of a condition in the contract requiring the consent of both parties to such a proceeding.

In recent arbitration proceedings between Gulf Oil Canada Limited and Trans-Canada Pipe Lines Limited, the arbitrators found that the field value of gas as of November 1, 1974, was 60 cents per Mcf, and accordingly named this as the redetermined price. The arbitrators also found that this price should continue for one year, and should then be increased to 73 cents per Mcf. ${ }^{253}$ Subsequently, the Alberta Supreme Court found that the arbitrators exceeded their jurisdiction under The Arbitration Act in awarding the increase of 13 cents per Mcf for 1975 and set this part of the decision aside.254

There have been two applications made to the Energy Resources Conservation Board for permits to remove gas from Alberta since the Board's 1972 review of field pricing of gas. ${ }^{255}$ In each case the Board reported to the Lieutenant Governor in Council whether the price offered to purchasers conformed with the government's policy in this regard, and in one instance where the price was lower than the Board's estimate of field value of gas, the applicant subsequently raised the price before the approval of the Lieutenant Governor in Council was obtained.

While the government has been anxious to increase the price of gas removed from the province, it has tried to prevent this from affecting the

2so Oilweek, January 21,1974 at 51.

251 R.S.A. 1970, c.21.

252 The Arbitration Amendment Act, 1973, S.A., c.88. The new section is numbered 16.1

${ }^{253}$ Gulf Oil Canada Limited and Trans Canada Pipe Lines Limited, Award, 11 April 1974.

254 As yet unreported.

255 In the Matter of an Application of Canadian Montana Pipe Line Company under the Gas Resources Preserva. tion Act, ERCB Report 73.A-OG at 2-4, 6-4 Calgary. March 1973 and In the Matter of an Application of Pan. Alberta Gas Ltd., supra, n. 207 at $11-3$. 
price paid for gas by Alberta consumers. In November 1972, Premier Lougheed announced a two-price policy for gas as part of his government's Statement of New Natural Gas Policies for Albertans. 256 This has recently been implemented through a system of rebates paid to vendors of gas for consumption or use in Alberta. ${ }^{257}$ The Public Utilities Board is also empowered to fix the price of gas used or consumed in the province. 258

It is clear that the free market has had little to do with the determination of prices for both oil and gas during Alberta's production life. Government regulation has been significant. In the case of oil, the price has been affected by the system of market demand prorationing, the exclusion of foreign oil from Canadian markets west of the Ottawa Valley, and the United States oil import programme. In the case of gas, the Alberta government has intervened through its system of gas export permits, the National Energy Board has had an impact in its decisions on exports to the United States, and the Federal Power Commission was successful for many years in keeping the prices of both domestic and imported gas in the United States below market levels. Furthermore, the absence of competition in the purchase of gas has undoubtedly been important. The question is not, therefore, whether government intervention is required in pricing matters, but which government can gain control of prices and how this control should be exercised.

The Alberta government has been successful in achieving substantial price increases for oil and gas during the last year. These have undoubtedly been of benefit to Alberta, both in terms of additional government revenues and higher returns to private enterprise. In this respect it is interesting to note that in 1972, when reporting to the government on field prices of gas, the Energy Resources Conservation Board entered into a detailed calculation of the social benefits and costs anticipated from an increase in gas prices, and found a considerable net social benefit for the province.259 This appears to be the first time that the Board has viewed the public interest in terms of net social benefits.

However, there has been an implicit assumption in Board reports and government action that price has no effect upon the quantities of oil and gas that may be sold in any time period. This may not have been unreasonable in the peculiar circumstances of late 1973 and early 1974, when energy shortages dominated the market in Canada and the United States. However, it is not generally the case. Perhaps the best example of this failure to consider the relationship between price and quantity is provided by the amendment to The Arbitration Act requiring arbitrators to fix gas prices according to commodity value. There is no single price at which gas becomes competitive with alternative sources of energy, but rather a schedule of prices at which different quantities of gas are displaced from various markets by such alternate sources. It thus seems impossible to assign a single figure to commodity value.

Moreover, both the present prices of oil and gas and consumers' predictions of future prices are important in the timing of development of oil and gas resources. If it is anticipated that the present value of

\footnotetext{
256 Supra, n. 246.

25: The Natural Gas Rebates Act, S.A. 1974, c.44. In special circumstances, rebates may be paid instead to pruchasers or eligible consumers of gas.

2sa The Gas Utilities Act, R.S.A. 1970, c.158, amended by S.A. 1973, c.91, s. 6.

239 Field Prices of Gas in Alberta, supra, n. 6 at s. 6.
} 
future prices will increase, there will be a tendency to delay production to the future, and vice versa. The Alberta government has demonstrated little concern for using prices to influence the rate of development of oil and gas resources in the province.

\section{CONCLUSION}

In the light of this review of the Alberta management system of Crown oil and gas resources, it is apparent that there are a number of problems to be faced in designing such a system. Firstly, a government is confronted with the highly inconvenient fact that information as to the location, extent and quality of its resources is not usually available and may be acquired only at a cost. Indeed, such information may not be fully obtained until the resources are actually produced. Secondly, there is an element of risk involved in exploration and development since the outcome of any investment is seldom certain. The risk factor is, in turn, a result of the information problem. Thirdly, it is clear that there are a number of market imperfections encountered at different stages of the management process which diminish the attractiveness of solutions based simply upon the competitive model. Such imperfections include a lack of competition in some activities, an absence of knowledge of future market conditions, especially regarding prices, and distortions produced by different taxation methods. Finally, there is the matter of political uncertainty, arising out of the established rule that an elected legislature cannot restrict the scope of its future legislative action, nor that of a successor, by entrenchment of policies for specified periods. In the case of Crown oil and gas resources, therefore, the duration of an existing management system is always open to doubt.

Right at the beginning, a government must deal with the problem of the lack of information through the use of the management system. A choice lies between using private enterprise and having the government acquire information on its own account. If private enterprise is used it must be remunerated. Traditionally, payment is in the form of an allocation of rights over some or all of the area explored. If rights are granted in exchange for information, it is difficult for the government to devise a system for collection of the economic rents in the absence of the very information which is to be generated. The cost to the public sector of this method of obtaining information is foregone economic rents. This system has always been employed in Alberta. The two-stage allocation process allows the acquisition of reservations by free entry, exploration by the holders of reservations, and conversion to lease in respect of 50 per cent of each reservation area. The Crown shares in the economic rents by sale of the surrendered areas and by imposition of production royalties and lease rentals. At the same time, though, the Crown loses the opportunity to collect a greater proportion of the economic rents from the retained leases. Private operators acquire such leases in exchange for the information that they have generated about the reservation area, and the Crown is precluded from obtaining further revenue by sale of these leases, as it does with Crown reserves.

Abandonment of the free-entry allocation system for reservations would have the effect of reducing the amount of Crown revenue given up in exchange for information. The Alberta government could exercise direct control over the granting of reservations in order to derive a benefit for the public sector from information spillovers. In particular, 
the government could retain all unexplored areas so long as their expected value was rising faster than the social rate of prime preference. It could also issue selected blocks in a region, on the basis of their ability to provide information on the region as a whole, and withhold the bulk of the available acreage until the results of exploration on the selected blocks were available. Any increase in the value of blocks in the region could then be collected by the government through the sale of further reservations. Of course, if the initial exploratory information was unfavourable, no increase in the value of adjoining blocks could be expected, but this would not result in any loss to the government as com. pared with the present free-entry system.

However, the Alberta allocation system also suffers from the disadvantage of causing considerable fragmentation of private rights within any given area. This fragmentation affects the development of an oil or gas pool either by adding to the costs incurred in concluding a unitization agreement, or by requiring the adoption of a system of production quotas to overcome the inefficient aspects of the rule of capture. In addition, the fragmentation of private rights contributes to information spillovers and thereby discourages private investment in exploration.

Whether the Alberta system for information-gathering should be retained depends finally upon a quantitative analysis of the following factors: the size of foregone economic rents, the extent of the disincentive caused by information spillovers, and the amount of additional production costs attributable to fragmentation of rights. The total loss in government revenue resulting from these factors should be compared with the cost to the public sector of government acquisition of information on its own account.

The case for government involvement in exploration rests upon the hypothesis that, up to a certain point at least, early access to information would allow the government to manage its resources better. For example, the argument runs, this information could be used to devise an allocation system for private production rights which would be capable of collecting additional economic rents sufficient to offset the cost of exploration. Furthermore, government exploration in the early stages could remove the necessity for fragmentation of rights and could internalize the effects of information spillovers. An argument frequently made against this theory is that a government would be unable to conduct exploration as efficiently as private enterprise. However, it is not necessary that a government agency actually carry out the operations itself. A government may contract with private exploration companies to do the required work for a cash payment instead of acquisition of oil and gas rights.

In practice, it seems that there is little dispute over the need for a government to collect information as this is a widespread and generally accepted practice. The difficult question is encountered in deciding how far a government should proceed with this activity at the public expense, prior to issuing production rights to private operators. In general, the answer is that a government should continue up to the point where the marginal social benefits from further collection equal the marginal social costs of acquisition. Needless to say, this is a fairly elusive criterion, for these benefits and costs will usually be difficult to estimate. However, this does not amount to an adequate reason for failure to attempt to do so. 
Irrespective of how information is generated, if a government chooses to issue oil and gas rights to private operators on a competitive basis, it seems likely that information should be made equally available to all participants in the competitive system. Otherwise, the system will probably be ineffective in obtaining the greatest potential revenue for the government. For example, the present Alberta method of selling Crown reserves often causes operators to bid with unequal access to information. This is so because private information acquired through exploration on a reservation is kept confidential for a year after selection of leases, even though the surrendered Crown reserves are frequently offered for sale within that period. ${ }^{260}$ Operators without access to all available information face greater risk in calculating bids, and if it may be assumed, as suggested later, that private operators discount the value of bids in accordance with the degree of risk involved, they will usually offer less for a block than the expected value calculated by the operator in possession of all the information. ${ }^{261}$ The operator will, of course, be in a position to anticipate this result and will therefore have an incentive to bid less than the expected value. The loser, in terms of revenue, will be the government. Putting the position another way, unequal access to information seems likely to act as a bar to effective competition in bidding which, in the long run, will normally cause a reduction in sale prices for oil and gas rights.

The obligation to share information equally would, however, act as a drastic disincentive to private enterprise to conduct exploration prior to the allocation of oil and gas rights. Thus the question of government involvement in exploration becomes more important. If the requirement for information sharing is accepted, the need for government exploration activity is more acute.

The second problem faced by a government in designing a management system for publicly-owned oil and gas rights, that of risk, also has particular relevance to the allocation process. Different methods of allocating oil and gas rights, and obtaining government revenue therefrom, cause the risk to be shared between private operators and the government in varying proportions. Cash bonus bidding places the risk squarely upon private operators because bids are usually calculated before the full potential of an area is known, and must be paid irrespective of success or failure in subsequent exploration. Gross royalties place some of the risk upon the government since payment of this part of the consideration is dependent upon the success or failure of exploratory operations. Net royalties place even more of the risk on the government because payment depends not only upon production but also upon profitable production. Direct government participation in operations goes a stage further if the government contributes to exploration and development expenses. Finally, of course, government bears all of the risk if it conducts all operations itself and allocates no rights whatsoever to private enterprise.

It follows that, in designing an allocation process for oil and gas rights, a government must decide who should bear the risk involved in exploration and development. Such a decision has implications regarding the exercise of control over publicly-owned resources. Allocation

\footnotetext{
260 Supra, at 159.

261 In any particular sale, lack of information may cause an operator to bid more than the calculated expected value. This cannot continue in the long run, though, or that operator would be forced out of business.
} 
systems which place most of the risk upon private enterprise generally allow the parties taking the risk to exercise a substantial measure of control over these resources, subject to any discretionary powers retained by the government and, of course, subject to resort by the government to the legislature for amendment of the relevant legislation. However, quite apart from control, there are efficiency considerations involved in this matter of bearing risk. Two principles are clear. Firstly, if the candidates for bearing risk are in fact averse to risk, they will require a reward for doing so. Secondly, such candidates will not necessarily all demand the same reward for bearing risk.

Aversion to risk is regarded here as a preference for one set of possibilities with a given expected value and specified dispersion over another set of possibilities with a higher expected value and greater dispersion. In other words, a risk-averse person must be given the incentive of a larger expected return before he will be prepared to accept a situation where the likelihood is greater that the outcome will deviate more significantly from the mean. It is occasionally suggested that some private operators in the oil and gas industry are not risk-averse, but in fact welcome the chance to "strike-it-rich" even against unfavourable odds. However, it is difficult to apply this theory to the vast majority of private operators, since it appears to be inconsistent with the very common practice of reducing risk by pooling among a number of joint ventures. A more reasonable approach seems to be that the industry as a whole is risk-averse. An explanation for this may be that the managers of firms are more concerned with avoiding failure than with taking an opportunity to make huge profits, regardless of the attitudes of the owners of the firms. This would be so if the consequences of failure were incommensurate with the rewards for success, or if managers found that uncertainty tended to complicate planning for the future. It seems likely that governments are risk-averse, too. Failure in a venture may suggest incompetence to the electing public and thereby carry substantial political penalties, whereas great success may not bring with it compensating political rewards.

If risk aversion may therefore be presumed in making policies for allocation of oil and gas rights, it becomes necessary to consider the remuneration demanded by private enterprise and by government for bearing risk. In both cases, it seems, the size of this remuneration will depend not only upon the intensity of risk aversion, a matter about which it is difficult to offer any suggestions, but also upon the extent of the risk borne. This latter factor is influenced by a number of things: the geological characteristics of the region, the state of the information available regarding these geological characteristics, and the opportunities for pooling risk. A government can do nothing to change the geological characteristics of a region. It can, however, acquire and distribute information, although at a cost to the public sector. The point to be made, though, is that a government should recognize the relationship that exists between risk and information. So far as reducing risk by pooling is concerned, this seems to be clearly possible among private operators. Large firms may pool risk internally by taking part in a number of operations while smaller firms may pool risk by entry into joint ventures. Either way though, there seems to be a cost to both the government and society in reducing risk. Reliance upon large firms to pool risk in oil and gas operations will cause a lessening of competition 
in the industry, precluding the use of a bidding system for allocating rights and requiring government intervention to regulate monopolistic or oligopolistic marketing practices. The effect of joint ventures on competition is difficult to ascertain. If small firms are otherwise unable to bid for rights owing to capital market imperfections or an inability to pool risk internally, joint ventures may add to competition. However, such ventures among firms which are capable of bidding independently cause a reduction in competition. In any event, joint ventures create transactions costs in the negotiation, recording and enforcement of agreements and these costs must be reflected in lower bids for oil and gas rights as well as representing social costs.

The question then becomes to what extent a government may be able to reduce risk by pooling within its boundaries. In general, this will depend upon the state of knowledge concerning oil and gas resources under its jurisdiction. If this knowledge is such that the government cannot determine whether economic deposits of oil and gas exist within its boundaries, the government would seem to be in a worse position to pool risk than private operators who may range across a number of provinces or countries, assuming, of course, that the government is restricted in its activities to its own territory. However, if available information is such as to make it very likely that oil and gas deposits will be found in a province without necessarily establishing the precise location or nature of these deposits, the government which owns the resources throughout the province will be in a good position to pool the risks encountered in searching for them, without cost to the public sector or to society.

The opportunity for government pooling of risk thus seems to be closely related to the extent of the geological risk involved in the region as a whole. It is impossible to be precise with regard to Alberta, but one thing is clear. The risk of failure has diminished considerably since 1946. With the discovery of Leduc in 1947, it became obvious that oil and gas were there to be found. This factor may explain the declining influence of the major oil companies in Alberta in recent years. During the early history of Alberta's development as an oil and gas province, when the geological risks involved in the region as a whole were substantial, it seemed likely that the major oil companies, with the benefit of their international operations, were in the best position to pool risk and that this advantage contributed to their dominance. With the subsequent discoveries and general upgrading of the geological potential of the province, the overall risk was reduced and new opportunities were presented for independent companies who could pool risk among a number of ventures within the province. It is suggested that in these circumstances the government could also reduce risk by pooling, and in its case without incurring the transactions costs which are characteristic of joint ventures. The time appears to have arrived when the government should assume the bulk of the risk involved in oil and gas operations in the province.

This implies a preference for systems of raising government revenue other than by cash bonus bidding. In fact, the logical extension of the argument is that a system of direct government involvement, through Crown corporations engaged in exploration and development or contracting with private operators for the performance of specific tasks, provides the solution. However, risk is only one element in the management of publicly-owned oil and gas resources. A system of direct govern- 
ment action will have its own drawbacks. In an industry where innovation and technical development have always played an important part, a Crown corporation not subject to local competition may rapidly become inefficient. Moreover, the failure to reap the advantages of decentralized decision-making may well prove significant. These factors do not, however, necessarily mean that a Crown corporation could not function effectively in competition with private enterprise. In the final result this may depend more upon psychological attitudes, such as that of public enterprise toward risk, rather than upon strictly economic considerations.

The third problem encountered in designing a management system for oil and gas resources, the presence of market imperfections, prevents a choice being made on qualitative grounds among the different methods of allocating private rights over these resources and obtaining government revenue therefrom. The cash bonus bidding system relies upon the maintenance of adequate competition, requires no divergence between private and social discount rates, and assumes reasonable foresight of future market conditions, quite apart from the matter of risk. The imposition of gross royalties affects both the timing and the quantity of private investment in exploration and development. An acreage rental also has an impact on such investment.

The inefficient aspects of gross royalties could be overcome by government subsidy of exploration and development. Direct government participation in exploration and production, in partnership with private enterprise, would achieve the same result, perhaps at lower administrative costs and probably with advantages regarding the acquisition of information. Net royalties also avoid the inefficiency of gross royalties if all economic costs, including an appropriate return on capital, are deducted. They are no different in principle to an income tax. However, net royalties have the same disadvantages as an income tax. The cost of administration is greater than in the case of gross royalties because allowable deductions must be specified, and an enforcement system maintained. Moreover, if net royalties are imposed at high percentages, a necessary requirement if a government is to collect a substantial proportion of the economic rents from production of its resources, they are likely to have a disincentive effect upon efficiency.

Finally, all of these mechanisms except competitive bidding suffer from one basic defect, in that if they are applied on a province-wide basis, they are incapable of taking full account of the quality differences among pools. Yet if they are applied on a pool by pool basis, effective administration requires detailed information regarding the characteristics of each pool. This difficulty illustrates the advantage that cash bonus bidding has over other revenue mechanisms. It allows the private operator to calculate whether a lease has an expected positive net value, after payment of all required royalties or other participation shares, and to bid this sum in addition to such other consideration. Competitive bidding also provides a means for selection of the operator to acquire each lease, based upon that operator's assessment of the lease value. It thereby avoids the administrative problems inherent in the selection of an operator according to other, more contentious criteria. However, whether it results in selection of the most appropriate operator, on efficiency grounds, is open to question. In the absence of uncertainty, there would be a tendency for the most efficient operator to submit the 
highest bid for each lease, since the benefits of that operator's lower costs would be reflected in the size of his bid. But in a climate of uncertainty this factor may be outweighted by the different expectations of operators regarding the quality of the lease and future market conditions. Nevertheless, despite this qualification, the cash bonus bidding system has definite advantages in raising government revenue and in avoiding administrative difficulties in selecting operators for leases. Therefore, whatever mechanism is primarily used for raising government revenue from oil and gas production, it may well be combined with an allocation system of cash bonus bidding.

The fourth problem encountered in managing oil and gas resources, that of political uncertainty, cannot be avoided entirely. Nevertheless, there is an advantage to be gained in reducing this uncertainty, for it represents a true cost to the private operator when investing in exploration and development, or when calculating a cash bonus bid. Perhaps the only way of effectively reducing this uncertainty is by the adoption of a practice of restraint on the part of government. However, such restraint is feasible for limited periods only. The oil and gas industry must recognize that if a government fails to revise its tenure arrangements for long periods of time, or when generally unforseen events occur, political pressures will become intolerable and change will inevitably follow, perhaps of an extreme nature. For this reason, the flexibility reserved to the government in the Alberta petroleum and natural gas lease is desirable, although it should be exercised with the objective of preventing rather than increasing political uncertainty.

For many years the Alberta government followed the practice of revising Crown royalties on oil and gas at ten year intervals. This tradition was broken recently in response to the dramatic shifts in oil and gas prices. It is suggested that the practice was a good one, but, at the same time, the breach was necessary in the circumstances and should not lead to future political uncertainty provided that a new tradition is established to replace the old.

At the production stage of oil and gas operations, the problems of information, risk and political uncertainty are diminished. Government intervention is required, however, because of market failure. The likelihood of a divergence between private and social rates of time preference means that controls upon rates or production from pools are necessary. Still, the present method of calculating maximum efficient rates to allow the greatest production of oil from pools should be amended to take account of society's time preference. The system of government sharing in production through gross royalties requires that the rate of development of pools, and particularly the timing and size of investment in enhanced recovery schemes, be monitored and, if the inefficient aspects of gross royalties are to be avoided, that the government subsidize private investment in exploration and development. The most important cause of market failure is, however, the rule of capture, which makes private operators treat the user cost of present production as zero. The method chosen for dealing with this problem, the market demand prorationing scheme, is open to criticism on efficiency grounds. ${ }^{262}$ The fate of this scheme should depend upon a measure of its inefficiency, in terms of social costs, compared to a measure of the transaction costs that would be incurred under a system of compulsory unitization. If a procedure 
were established providing for a unitization hearing before the Energy Resources Conservation Board, and a determination by the Board on the evidence presented, without the necessity of obtaining agreement from any specified number of owners, it seems unlikely that these transaction costs would be large. Moreover, such costs could be substantially reduced in future by adoption of an allocation system causing less fragmentation of private rights in a pool.

It is sometimes suggested that the inefficiency which results from the market demand prorationing scheme has produced a net social benefit for Alberta and that the scheme should therefore be retained. This is so, it is said, because the scheme has induced extra investment in drilling and production facilities, provided from outside the province. Such investment is tied to the oil and gas industry; if it is not used in oil and gas operations in Alberta, it will be lost entirely to the province. It is better for Alberta to have the investment placed in excessive drilling and development in the province, with the secondary benefits that flow therefrom, than to let it go to another jurisdiction.

However, what this argument overlooks is that this additional investment is financed by dissipation of potential economic rents. The choice for the Alberta government is not necessarily between more or less investment in the oil and gas industry. Where the government is the owner of the resources and can devise a system for collecting a substantial proportion of the economic rents, the choice is between more investment or more government revenue from these resources. This being the case, the argument in favour of the inefficiency induced by the market demand prorationing scheme has merit only where the additional investment in oil and gas operations yields a greater social benefit than any available form of government expenditure, including a reduction in provincial taxes. This is an unlikely situation.

Transportation does not appear to have given rise to the same possibilities of inefficiency or revenue loss to date as have exploration and production. The example presented by the Alberta Gas Trunk Line Company Limited is interesting in that it shows how a Crown corporation could operate in this field. In this situation of near or natural monopoly, the choice for a government lies between regulation and ownership. It is not clear that one has significant economic advantages over the other.

In the areas of control over exports and pricing, the government is faced with the necessity of estimating social benefits and costs. Apart from questions of government revenue and the level of investment in oil and gas operations, this calculation will be concerned with the effects upon consumers of different export and pricing policies. Any narrower approach which does not take overall benefits and costs in the province into account, such as the present export policy for gas aimed solely at security of supply, is difficult to justify. Here, the interrelationship of the different stages of the management system for oil and gas is vitally important. Price undoubtedly has an effect upon both exploration and production, as well as government revenue therefrom, although the degree of this impact is not known precisely. Therefore, price regulation may be used as an instrument for influencing rates of exploration and development. In the same way, the current policy for controlling gas exports affects exploration, development, and government revenue. It may be asked whether the Alberta government should attempt to control ex- 
ports directly or endeavour to achieve the same result through its allocation system for Crown oil and gas rights and the regulation of wellhead pricing. ${ }^{263}$ The interrelationship of these effects gives the government considerable flexibility in the choice of its policy instruments, but at the same time requires that the effect of controls imposed at any stage of the system be considered throughout the entire system. ${ }^{264}$

In fact, however, one characteristic of the Alberta management system for Crown oil and gas resources is the absence of unity of purpose. Different parts of the system apparently strive for different objectives. The allocation process, which is administered by the Department of Mines, includes a number of features with a tendency to accelerate investment in exploration and development. Among these are the free entry system for acquiring reservations in unexplored areas, government subsidies for exploratory drilling, work commitments attached to reservations, renewal conditions for leases encouraging development drilling, and the imposition of lease rentals. It would seem that the Department of Mines regards early exploration and development as a good thing. But this is achieved at the cost of government revenue either directly through payment of subsidies or indirectly through reduction in the size of the economic rents available for collection. At the same time, the Energy Conservation Board continues to administer the market demand prorationing scheme to deal with the problems of overproduction, again at the cost of potential government revenue. Similarly, in the case of gas the Board requires the maintenance of a substantial inventory of proved reserves in Alberta before allowing the removal of gas from the province, a procedure which has a definite impact on the timing of exploration and development. It may be asked whether the combined effects of these conflicting management policies have been adequately assessed. ${ }^{265}$

Co-ordination among the different stages of the management system has been sought through the establishment of the Energy Committee. ${ }^{266}$ Nevertheless, if co-ordination is to be achieved, the onus lies upon the government to establish clear objectives applicable to the system as a whole. It is suggested that, since the resources in question are publicly owned, the fundamental objective should be to obtain the maximum net social benefit from them subject to an acceptable distribution of this benefit. The criteria of efficiency and equity employed in the evaluation of the present Alberta management system contribute to the attainment of this objective. Efficiency is defined in terms of the best possible allocation of society's resources of labour and capital among alternative uses, both present and future, resulting in the largest possible net benefits to society. Equity refers to the distribution of net benefits from oil and gas development, as between the government and the remainder

20s There would be considerable doubt about the validity of The Gas Resources Preservation Act if the federal government should try to control the interprovincial movement of gas: see Crommelin, supra, n. 196, Part I at 56.

264 Controls over exports and pricing have particular relevance to the consuming provinces in Canada. Policies may therefore reflect compromises for national purposes. However, this should not preclude a consideration of the best policies from Alberta's viewpoint, as bench marks for assessment of such compromises; supra, at 148 .

265 A rational explanation does exist. The government of Alberta may be using these different policies to encourage early discovery of reserves and at the same time, to maintain substantial inventories of proved reserves of oil and gas. If 80 , the cost of this method of doing so should be compared with the cost of the alternative means of achieving the same result, namely government exploration of retained acreage.

286 The Committee consists of the President of the Executive Council, the Deputy Minister of the Environment, the Deputy Minister of Industry and Commerce, the Deputy Minister of Lands and Forests, the Deputy Minister of Mines and Minerals, the Chairman of the Energy Resources Conservation Board and the Chair. man of the Public Utilities Board; The Energy Resources Conservation Act, supra, n. 105 at 8.19. 
of society. It is submitted that equity is fully achieved only when the government succeeds in capturing all of the economic rents from production of Crown oil and gas resources, these rents being the surplus value that the resources have over all necessary costs of production.

It needs to be emphasized, though, that the problems of information, risk, market imperfections and political uncertainty, which are encountered in devising a management scheme for oil and gas, give rise to considerable difficulty in the application of these efficiency and equity criteria. Since it is not possible to have a management system which is both completely efficient and entirely successful in obtaining all of the economic rents for the government, it becomes necessary to compare less then perfect alternative arrangements. In doing this, the interrelationship that may exist between the efficiency and equity criteria becomes apparent. For example, one method of allocating oil and gas rights may have substantial advantages in terms of efficiency, but may be incapable of capturing a large share of the economic rents for the government. On the other hand, an allocation system which is clearly inefficient and thereby reduces the total size of the economic rents may succeed in capturing a high proportion of those reduced rents. It will not be possible to choose between the two systems on purely qualitative grounds. Faced with this difficulty, it seems that the best course that a government can follow, especially in the situation where it is dealing with an industry that is owned to a large degree by non-residents of the province, is to seek to obtain a balance between the size of government revenue and the extent of inefficiency. The more revenue that can be obtained without adding to inefficiency, the better the management system, but when the point is reached where further revenue is available only at the expense of efficiency, a compromise must be struck.

In practice, quantitative analysis is required in the evaluation of a management system. The extent of distortions produced by different policies, and their impact upon the level of government revenue, should be measured. This, of course, amounts to a formidable task but in the absence of data obtained by such research it is impossible to be sure about which management system would produce the maximum net social benefit.

Nevertheless, in a world where decisions must frequently be made without the advantage of adequate empirical research, it may fall to a government to revise its management system for Crown oil and gas resources without full knowledge of the consequences thereof or the identity of beneficiaries and losers. It is on such a basis, and without wishing to detract from the importance of the necessary quantitative analysis, that the following suggestions are made regarding management of Crown oil and gas resources in Alberta.

The government should establish a Crown corporation to conduct basic exploration for oil and gas, in competition with private operators. The exploration programme of this agency, which need not perform the work itself where private companies are available to do so on a contract basis, should be directed towards improving the state of information upon tracts before they are offered for lease. The information acquired by the corporation should be used by the Department of Mines for estimating the best tracts to be made available to private operators for development, and the time at which such tracts should be offered. The two-stage allocation system for private rights should be abandoned in 
favour of a one-stage system of issuing leases with the same production rights as are presently available under the Crown petroleum and natural gas lease. The allocation method for leases should be cash bonus bidding, as used at Crown reserve sales. The Department of Mines should use the information obtained from the Crown exploratory agency to calculate minimum acceptable bids for leases on the basis of the present social value of tracts. The Department should also monitor the level of competition in bidding, and reject all offers where competition is deemed to be inadequate. The areas of tracts offered for lease should be determined by reference to the dimensions of pools likely to be discovered, bearing in mind the necessity of reconciling the problems of fragmentation of rights in a pool and the capital requirements for an effective exploration and development programme. All information available upon areas offered for bids should be released to private operators in time to allow interpretation, evaluation and calculation of bids, thereby avoiding the present situation where private operators bid for leases with unequal information. The present system of gross royalties should be discontinued in future leases in favour of direct participation by a Crown corporation to a degree announced in each invitation for lease bids. Participation should include contribution to all exploration and development expenditures. The extent of the government interest should be subject to redetermination at regular intervals announced prior to the sale, and designed to reduce political uncertainty in the calculation of bids, without unduly restricting the scope of future government action. Production practices should be subject to review by the Energy Resources Conservation Board as at present, and maximum efficient rates of oil and gas should be stipulated by the Board, having regard to the geological characteristics of individual pools and the social rate of time preference. Market demand prorationing should be phased out over a period of years. In its place, the Board should be empowered to require unitization of all pools or severable parts thereof, either by approval of an agreement reached between private operators or by order of the Board after an open hearing into the matter. Export controls on gas should be replaced by controls on the allocation of leases and production therefrom, and the position of the Alberta public as regards future supplies should be protected through the allocation system and the retention in the province of the Crown's share of production to the extent required. The regulation of pricing of oil and gas in Alberta should be preceded by a detailed study of the social benefits and costs flowing from price changes, including a public hearing on the issue before the Energy Resources Conservation Board. 